Rhode Island College

Digital Commons @ RIC

$12-1-2018$

\title{
Anesthetic Use and Cancer Recurrence in the Surgical Oncological Patient: An Integrative Review
}

Amanda Hauser

Follow this and additional works at: https://digitalcommons.ric.edu/etd

Part of the Nursing Commons

\section{Recommended Citation}

Hauser, Amanda, "Anesthetic Use and Cancer Recurrence in the Surgical Oncological Patient: An Integrative Review" (2018). Master's Theses, Dissertations, Graduate Research and Major Papers Overview. 284.

https://digitalcommons.ric.edu/etd/284 
ANESTHETIC USE AND CANCER RECURRENCE IN THE SURGICAL

ONCOLOGICAL PATIENT:

AN INTEGRATIVE REVIEW

\author{
By \\ Amanda Hauser \\ A Major Paper Submitted in Partial Fulfillment \\ of the Requirements for the Degree of \\ Master of Science in Nursing \\ in \\ The School of Nursing \\ Rhode Island College \\ 2018
}




\begin{abstract}
This integrative review compared anesthetic usage and its impact on the cancer patient. Immunosuppression from anesthesia can have major impacts on the human body’s immune system and lead to a decrease in overall patient survival and an increase in cancer recurrence rates. A search was completed using electronic databases including CINAHL, PubMed Health, and Medline Plus. The studies were located with keyword searches and inclusion and exclusion criteria was used to locate a final 8 studies for the review. A critical appraisal was completed using Polit and Beck’s critical analysis tables, displaying key characteristics of the studies chosen. Outcomes reviewed included overall survival rates, cancer recurrence rates, time to recurrence and biomarker identification. The findings presented more beneficial outcomes with regional anesthesia, but larger prospective randomized studies are needed to validate these findings. Regional anesthesia has shown to increase time to recurrence, decrease recurrence rates, and limit the increase in immune biomarkers. However, regional anesthesia does not fully support an increase in overall survival rates. More research and randomized control trials are warranted on this topic. Overall, this integrative review has supported the use of regional anesthesia for more positive outcomes in the oncological surgical patient over general anesthesia.
\end{abstract}




\section{Acknowledgements}

I would like to acknowledge my husband, Aref, for supporting me through this entire program and picking me up every time I felt I could not continue. Thank you for all the hours you spent consoling me and making me feel that this was the right path for me. I would not be where I am today without you. 
Table of Contents

Background/Statement of the Problem......................................

Literature Review......................................................5

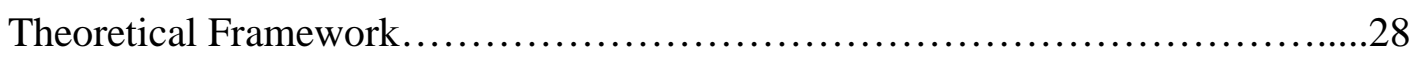

Method.................................................................. 30

Results.............................................................. 32

Summary and Conclusions.................................................50

Recommendations and Implications for Advanced Nursing Practice...............56

References........................................................... 59

Appendices...............................................................68 
Anesthetics and Cancer Recurrence in the Surgical Oncological Patient:

An Integrative Review of the Literature

\section{Background/Statement of the Problem}

An estimated 234 million surgeries are undertaken every year world-wide (Weiser et al., 2008) and of this 234 million, an estimated 20\% are related to cancer (Hoekstra et al., 2015). Cancer is a global epidemic, being the leading and most common cause of death worldwide (Torre et al., 2015). This is amplified by the increasing age and growth of our population. The rise in cancer cases is strongly associated with an increase in sedentary lifestyles, poor diets and smoking (Torre et al., 2015).

The word 'cancer' constitutes immediate negative connotations for valid reasons. Each year in the United States over 1 million cases of individuals diagnosed with cancer are recorded (Le-Wendling, Nin, \& Capdevila, 2015). In 2012, 14 million new cancer cases were documented, and 8.2 million cancer deaths occurred globally (Torre et al., 2015). An additional 1.6 million cases were diagnosed in 2016 and of these cases an estimated 33\% will die from the developed disease (Bharati, Chowdhury, Bergese, \& Ghosh, 2016). These staggering figures provide us with a clear picture of why cancer remains one the leading causes of mortality in the world.

\section{Increased risk factors for cancer development}

Threatened populations. Certain populations are at greater risk for cancer development, such as men and the elderly. The incidence in North America of cancer in men versus (vs.) women was 344:295 out of 100,000 (Torre et al., 2015). The cancer mortality rate per 100,000 of men vs. women was 123:91 (Torre et al., 2015). The underlying reasons for this disproportion relate closely to the differences in lifestyle of 
men and women. Men show a higher tendency to participate in modifiable risk factors like alcohol consumption, cigarette smoking and physical inactivity (Torre et al., 2015).

Elderly. For the elderly population, the incidence is focused at the cellular level. The physiologic changes associated with aging promote cellular change from the buildup of oxidative free radicals and effects on the mitochondrial DNA. With time, the accumulations of mitochondrial DNA mutations lead to an increase in reactive oxidative species. Buildup of free radicals become harmful in large amounts to the body. In addition to the physiologic changes, our environment is also to blame for mutations (Tosato, Zamboni, Ferrini, \& Cesari, 2007). Environmental toxins play a role in mitochondrial DNA damage, furthering mutations with time. These non-modifiable factors contribute to homeostatic changes in the body and place our elderly population at greatest risk for cell mutation and cancer development.

Patients undergoing surgical interventions. In many cases, surgical interventions are considered the benchmark treatment for solid malignant tumors. The role of the stress response during and after surgery can have both positive and negative effects on the body. The primary function of the stress response is to promote healing. Occasionally, the stress response can also be the catalyst for micro-metastasis and promote cancer spread (Gottschalk, Sharma, Ford, Durieux, \& Tiouririne, 2010). Stress can be perceived as a hazard to the body’s natural homeostasis with a known link existing between inflammation, immunity and neoplastic growth. The surgical stress response suppresses the immune system resulting in an acceleration of malignant growth and metastases (Kurosawa \& Kato, 2008). Surgical interventions have shown to trigger immune suppressive responses and support new tumor growth or new locations for 
metastases (Bharati et al., 2016).

Anesthesia impact. Immunomodulation from surgical stress represents one of the surgically related risks for cancer expansion. An integral piece of the surgical care plan involves the use of anesthesia. The body's response to anesthesia can hinder the immune system and promote metastatic spread (Exadaktylos, Buggy, Moriarty, Mascha, \& Sessler, 2006).

Each case and each patient determine the type of anesthetic plan that will be delivered for the surgical procedure to ensure adequate patient safety. The choice of anesthetic provided will have varied effects on cell-mediated immunity. General anesthesia, involving the use of volatile anesthetic gases, has been documented to influence cancer recurrence. General anesthesia does this by inducing apoptosis of immune cells, causing stress to the body and tumor metastasis. General anesthesia has shown a direct suppression of cellular immunity, specifically to the body's innate immune cells (neutrophils, macrophages, dendritic cells, T-lymphocytes, and natural killer cells). The innate immune system becomes activated when barriers are compromised due to injury. Initial responders, natural killer cells (NKC), magnify the immune response to provide protection against viral infections and oncologic disease (Stollings et al., 2016). Volatile gases directly suppress this mechanism, leaving the body exposed and unprotected, not only during surgery but several days following (Stollings et al., 2016). A combination of direct suppression from general anesthesia, immunosuppression, and neoangiogenesis from surgical stress, have been identified as predisposing the host to tumor metastasis.

The perioperative phase is a vulnerable period of immune compromise for 
patients as a result of the surgical stress response (Bajwa, Jit, Anandl, \& Kaur, 2015). The added anesthetic influence during this time, and postoperatively will be reviewed to support or reject its use with the cancer population.

The purpose of this project was to explore the literature from 2006 - present time to identify the best anesthetic practice for the oncological surgical patient. Current literature was compared to past studies to examine the evolution and advances in the knowledge of anesthesia techniques and their effect on immunomodulation and cancer recurrence. By reviewing both past and present literature, a better understanding of existing relationships between anesthetics and the effects on cancer recurrence and metastasis in the surgical patient was identified. An integrative review was conducted with an aim to identify the impact of anesthetics on cancer recurrence and metastasis in the surgical oncological patient.

Next, a review of literature relevant to anesthetic use and cancer recurrence in the surgical oncological patient is presented. 


\section{Literature Review}

The literature presented here will provide general background on cellular changes associated with cancer, effects on the immune system in relation to cancer, surgical stress response on immunomodulation and anesthetic impact on the compromised patients' immune system. Immunomodulation from anesthesia and the impact on recurrence and metastasis of the cancer cells after anesthetic delivery will also be explored. Data were searched from 2006-present for this review.

Searched databases include CINAHL, Medline Plus, and PubMed Health.

Keywords: anesthesia, cancer, recurrence, anesthesia, neuroendocrine stress, surgery, immune system, immunosuppression, cancer cells, natural killer cells, regional anesthetics, general anesthesia, volatile anesthetics, opioid impact The primary aim of this project was to determine the effects of anesthetics on the immune system and their impact on cancer recurrence and metastasis in the oncological surgical patient. This project also intended to further identify the influences of anesthetics on the cellular immune system, and the stress impact on the human body leading to cancer recurrence. Topics for review included: the effects of stress on immune function, cancer and the surgical stress response, natural killer cell response to cancer invasion, and anesthesia's impact on immunomodulation. These topics are relevant and valuable to the discussion of anesthetic impact on cancer recurrence. Immunomodulation begins with stress and unfolds as additional insults are made to the immune system by certain anesthetics used during the surgical phase of treatment. One must understand the initial physiologic effects of stress to understand why the addition of anesthesia places the vulnerable patient at an even greater risk. 


\section{Effects of stress on immune function}

Tosato et al. (2007) identified the leukocyte as the main modulator of innate immunity, inflammation and stress. As we age, chronic stress becomes more common on the body and an influx of leukocyte activity eventually leads to chronic inflammation. With constant activation, leukocytes enter a phase of exhaustion resulting in T-cell immunity shrinkage and progression to pathogen susceptibility (Tosato et al., 2007). Two of the regulatory proteins activated by the immune system are described as: proinflammatory cytokines and anti-inflammatory cytokines. Proinflammatory cytokines include tumor necrosis factor (TNF) and interleukin (IL) 1B, IL-6 and IL-8, while antiinflammatory cytokines include IL-10 IL-1RA, TNF binding factors 1 and 2. These cytokines will be referenced throughout this review.

Stress and its effect on the immune system is dependent on the circumstance. The body’s natural response to a dangerous situation puts the body into survival mode, or 'fight-or-flight'. During this time the body delays immune suppression to optimize defense mechanisms when they are needed the most. This short-term, acute stress response may play a protective role in the body as stress hormones and neurotransmitters prepare the immune system for possible challenges experienced by the brain (Dhabhar, 2009). By contrast, the body is known to suppress the immune system during prolonged bouts of chronic stress. Chronic stress has been shown to dysregulate immune function and is thought to play a role in the etiology of many diseases (Dhabhar, 2009).

Chronic long-term stress can be immunopathological and immunosuppressive. Chronic stress can decrease baseline leukocyte numbers, suppress leukocyte function and mobilize immunosuppressive mechanisms, like regulatory T-cells (Dhabhar, 2009). This 
results in a lower efficacy of vaccinations, prolonged wound healing and less resistance to infection and cancer. Chronic stress also appears to mobilize inhibitory mechanisms and is likely to exacerbate proinflammatory and cytokine responses increasing susceptibility to infections and cancer.

A case-controlled study conducted by Saul, et al. (2012) evaluated the effects of chronic stress in SKH1 mice susceptible to ultra violet (UV) induced squamous cell carcinoma. Sixteen mice were exposed to UV radiation. Half of the mice exposed were left in non-stressed situations (remained in their cages), while the other half of the mice were exposed to chronically stressful situations (restrained and removed from normal habitat). The results showed that the stressed mice had a shorter median time to first tumor, 15 vs. 16.5 (15:16.5) weeks and reached tumor incidence earlier than the nonstressed group. Further data indicated that the stressed mice had higher numbers of tumor infiltrating and suppressor cells (CD4+, CD25+) in circulation than the non-stressed mice, which lead to a suppression of antitumor activity. The non-stressed group showed $30 \%$ regression at week 34 with no new tumors, while the stressed group did not demonstrate any tumor regression, but a 16\% tumor number increase (Saul et al., 2012). Saul et al. (2012) concluded that chronic stress increased susceptibility to the UVinduced carcinoma by suppressing skin immunity.

Chronic stress also has the ability to alter gene expression. In a study conducted by Flores et al. (2017), adult male rat prostate tissue was studied after stress exposure. Rats exposed to repeated stress were compared to an unstressed group, and a group that was allowed to recover for 14 days following the stressful event. Prostate tissue was collected from the rats prior to exposure and then frozen for gene expression analyses by 
PCR array. After exposure, rats were transcardially perfused and identification of neuronal activation was completed by brain tissue harvesting. Elevations in the Fos expression from the brain tissue staining were noted in the stressed mice. The data collected from the PCR arrays identified an increase in genes associated with cellular proliferation in the repeatedly stressed rats and the recovery rats (Flores et al., 2017).

Data further identified both acute stressed and chronically stressed rats demonstrated significant metastatic changes in gene expression. The alteration in growth factor and apoptotic genes suggest stress is an inducer to pathway changes for prostate cancer. Flores et al. (2017) conclude that their findings support the idea that by interfering with neuroendocrine mechanisms, stress may have a large impact on cancer outcomes.

Just as we have natural responses to stressful situations with immune activation, such as wounds and infection, many non-natural situations like surgery and vaccinations also induce a stress response. Stress is a major factor during the diagnosis, treatment, and follow-up for most diseases. Surgical interventions are particularly strong creators of stress and are known to be immunosuppressive and thus may result in an increased risk of neoplastic growth.

Natural Killer Cells and Cancer. The immune system is the human body's protection from harm, yielding physiologic changes to infections or injuries. Our immune system has numerous functions, including: elimination of invading pathogens, identification of harmful insults to the body, and fighting mutated cells secondary to illness. While there are a myriad of processes and activations that affect the immune system, the main fighter cell involved in cancer eradication is the natural killer cell. 
Natural killer (NK) cells play an important role in cell-mediated immunity. Part of the innate immune system, NK cells can identify foreign invaders such as tumor cells or viruses through surface markers. Natural killer cells are a type of leukocyte cytotoxic tumor cell (Le-Wendling et al., 2016). These cells are unique because they are tumor preventers, aiding the body by directly killing tumor cells without initial priming, unlike other immune cells. A down regulation of the major histocompatibility complex (MHC), or the absence of MHC-I, signals NK cells to attack. The decrease or lack of MHC is associated with invasive tumor presence. NK cells are the primary metastatic eradicator for the human immune system (Welden, Gates, Mallari, \& Garrett, 2009). Under surgical stress, the NK cell is suppressed and places the patient at risk for metastasis.

Platelets and fibrinogen also appear to play a role in metastasis through impediment of NK cell potential. Platelets influence metastatic potential due to the cellular growth factors and inflammatory mediators contained in their granules. Platelets additionally support endothelial adhesion and aid in tumor formation. Their activation supports transmigration out of the vasculature and prevents innate immune cells from interacting with tumor cells, thereby inhibiting NK cell-to-cell contact for elimination (Palumbo et al., 2005).

Palumbo et al. (2005) examined the role of platelets in tumor cell growth and dissemination. Palumbo et al. (2005) examined mice lacking Gaq (a protein needed for platelet activation) and Gaq positive (+) mice. Three time cohorts (20 minutes, 5 hours, and 24 hours) of 5 mice for Gaq negative (-) and Gaq positive (+) were used. All cohorts were intravenously injected with Lewin lung carcinoma (LLC) to examine circulating tumor cell fate. The cohorts were killed at 20 minutes, 5 hours and 24 hours after tumor 
cell injection and distribution of LLC was measured. Twenty minutes post injection, tumor cells were noted 50\% in the lungs of both groups. A wide distribution of cells showed $<5 \%$ in blood, $<10 \%$ in liver, and $<1 \%$ in the spleen of the mice. Time dependent tumor elimination of Gaq (-) mice was shown with $10 \%$ remaining at 24 hours, and only $1 \%$ of tumor cells after the 24 hours, compared to $15 \%$ in the Gaq + mice. Palumbo et al. (2005) concluded that their findings suggest a link between platelet activation and circulating tumor cell survival.

Palumbo et al. (2005) also explored NK cell impact on tumor cell. The investigators formed a barrier to prevent the NK cells from interacting with malignant cells within the pulmonary vasculature. By depleting NK cells in Gaq - mice, using antiasialo GM1 polyclonal antibodies, a barrier was created. The process was verified by collecting splenic effector cells that demonstrated no NK function after administration. The Gaq - and Gaq + groups were once again used, with 5 mice from each group being injected with the LLC. Tumor cells, like the previous experiment, were significantly lower 24 hours post in the Gaq - mice $(p<.03)$ (Palumbo et al., 2005). Mice pretreated with the polyclonal antibodies showed a decrease in tumor cell number in the Gaq mice, and an increase in tumor cell numbers in the lungs of Gaq + mice (Palumbo et al., 2005). This further supports NK cells' importance in tumor cell eradication and platelet activation in tumor cell survival. Palumbo et al. (2005) demonstrated the platelets position in enhancing metastatic potential by impeding tumor cell clearance by the NK cells. By controlling platelet activation, NK cell activity could function properly and maintain tumor cell control. 
As disease progresses and more tissue injuries are sustained, platelet activity is increased, and NK function is suppressed. This allows metastatic cell spread due to lack of circulating NK cells within the body leading to advanced disease (Levy, Roverti, \& Mordoh, 2011). Because NK cells have the ability to defend the body from metastatic spread, any inhibition of their function will consequently increase the probability of cancer recurrence, or metastasis. What is even more consequential is that the surgical stress response has been shown to directly suppress NK cells during the perioperative period (Bharati et al., 2016).

\section{Cancer and surgical stress response}

Surgery remains the primary intervention for solid tumor cancer treatment. Other treatments include radiation, chemotherapy, and endocrine therapy. However, surgical removal of the disease is assumed to provide the best prognosis for these patients (Exadaktylos et al., 2006). During surgical interventions, the body undergoes cellular changes in response to treatment. The metabolic, neuroendocrine and cytokine responses elicit a sequential stress response in the human body leading to a breakdown of the defense system (Exadaktylos et al., 2006). This is known as an inhibition, or suppression, of immunity within the body, which leaves the host unprotected and at risk for undesired invasion. Host defense remains important during surgical manipulation of tumors because possible dissemination of tumor cells into the systemic circulation becomes a potential risk.

Gottschalk et al. (2010) identified cancer as one of the leading causes of death due to metastatic recurrence. This incidence is related to lingering disease, tumor dormancy or intraoperative tumor cell spread. During surgical stress, suppression of cell mediated 
immunity mechanisms become vulnerable and depressed, allowing cancer cells to spread. Immunosuppression from surgical stress can last hours to days leaving large amounts of time for invasion and poor outcomes (Gottschalk et al., 2009).

The release of chemical mediators from surgical stimulation can influence cancer growth by disrupting the homeostatic nature of the tumor itself (Gottschalk et al., 2009). Chemical mediators promote the release of catecholamines causing a subsequent cascade release of adrenocorticotropic hormone and cortisol. This cascade causes inhibitory effects on the immune system and further supports immune suppression.

Cancer metastasis is a very complex process within the cell. Other than NK suppression from chemical mediator release, inflammatory system cascades are established and potentiate problems further leading to cancer progression. The addition of cytokines (IL-10, IL-6), cyclooxygenase, prostaglandins and chemokines, products of the inflammatory system, are promoters for immunosuppression and cancer development and have been linked to increasing the duration of NK inhibition postoperatively (Gottschalk et al., 2009).

Narita et al. (2013) evaluated perioperative serum inflammatory cytokines and three stress markers: body temperature (BT), white blood cell (WBC) count and Creactive protein (CRP) in patients with prostate cancer. A comparison of surgical stress in patients who underwent open radical prostatectomy (ORP) vs. laparoscopic radical prostatectomy (LRP) was completed by measurement of serum cytokine levels. One hundred and sixty-five patients were included in this quantitative study. Levels of serum cytokines were taken preoperatively (PO), immediately postoperatively (IPO) and one day postoperatively (POD1). Using the BD Cytometric Bead Array Human Inflammatory 
Cytokine Kit, six inflammatory cytokines (Interleukin 10, 6, 1B, 8, 12 and tumor necrosis factor (TNF) were measured. All data were analyzed using the CBA software program. For all patients, the BTs, WBC counts, and IL-10, IL-6, IL-1B and IL-8 were each significantly elevated IPO vs. PO ( $p=.002, p<.001, p<.001, p=.009, p<.001, p<001$, respectively). On POD1, BT, WBC count, IL-10 and IL-6 continued to be considerably higher than PO ( $p$.001) (Narita et al., 2013). When evaluating between the ORP vs. LRP, there were no significant differences in stress markers or serum cytokines PO or IPO. The WBC was the only identifiable difference, shown to be lower IPO in the ORP (10,877 cells/uL) vs. LRP (11,993 cells/uL). At POD1, ORP showed higher BT, WBC, and CRP compared to LRP. After final evaluation, Narita et al. (2013) concluded that there was a relationship between stress response and tissue damage. These authors identified BT, WBC, IL-10 and IL-6 as surgical stress markers (Narita et al., 2013). Surgical stress markers may be a useful tool for future studies to help identify the presence of inflammation as well as to identify potential immune system suppression.

Natural Killer cells and the surgical response. Tai et al. (2012) evaluated the suppressive effects of surgical stress on NK cells. These researchers conducted an experimental study which examined 4 groups of mice all injected with 3e5B161acz cells (cancer cells). The groups included: mice with surgical intervention, mice with no surgical intervention, mice with surgical intervention and NK cell deficiency and mice with NK deficiency but no surgical intervention. The mice subjected to surgical intervention underwent abdominal laparotomy and left nephrectomy, 2 days after the intravenous infusion of 3e5B161acz cells to establish pulmonary metastasis. Three days post-surgery, a twofold increase in pulmonary metastasis was found in mice that 
underwent surgical intervention (400\%) vs. the mice that did not (200\%). In the NK-cell depleted mice, surgical stressed and non-stressed mice both developed increased numbers in lung tumors (900\% vs. $750 \%)$. Interestingly, the NK deficient mice were noted to have a faster pulmonary metastasis at 3 days vs. the mice with normal NK cell function (Tai et al., 2012). Tai et al., (2012) identified the importance of the NK cell presence and tumor metastasis.

Tai et al. (2012) observed changes in protein levels, consisting of increased cytokines and chemokines over time, as compared to the non-surgical intervention mice. These authors further observed an increase in IL- 5 and IL- 6 and tumor growth factor (TGF) in all the surgically stressed mice (Tai et al., 2012). All three of the above cytokines have immune-suppressive properties further identifying immune suppression factors released during the surgical stress response. Tai et al. (2012) concluded that the increase in serum cytokines, IL-5, IL-6, and TGF, may contribute to the dysfunction and suppression of NK cells late in the perioperative and postoperative phases.

\section{Anesthesia and immunomodulation}

Anesthesia is a medical treatment that eradicates the feeling of pain during invasive surgery. The use of anesthetics has made numerous surgical procedures possible and has improved the quality of life for many. In addition to providing amnesia, analgesia, and immobility, anesthetics play a key role in inflammation and the immune system. Anesthetics contribute to immune alteration by temporarily activating the antinflammatory and proinflammatory responses. These responses are involved in the modulation of our innate immune system, leaving the human body vulnerable to invaders (Loop et al., 2005). Loop et al. (2005) studied the effects of Sevoflurane, Desflurane, and 
Isoflurane, types of volatile anesthetics, on human T-lymphocytes in vitro. Using an airtight chamber, Loop et al. (2005) investigated which gases initiated apoptosis of Tlymphocytes. This quantitative, experimental study used 95\% air and 5\% carbon dioxide mixture for the control. Sevoflurane was dosed at 2.5\%, 5\%, and $8 \%$, Isoflurane at $1.5 \%$, $2.5 \%$ and $5 \%$ and Desflurane at $6 \%, 12 \%$, and $18 \%$ volume (differences in percentages are based on MAC values). For each gas chamber, 10 human T-lymphocytes were used and exposed for 24 hours. After exposure, the cells were stained and frozen immediately until protein extraction took place. The results showed that the control cells did not have any increase in the number of GRP-annexin, V-positive apoptotic cells (Loop et al., 2005). Sevoflurane showed an increase in apoptotic cells from $2.57 \%$ to $8.01 \%$ (16\% vs. $4 \%$ of control). Isoflurane showed an increase of apoptotic cells from $0.7 \%$ to $4.8 \%$. Desflurane exposure did not show any increase in cellular apoptosis of T-lymphocytes (Loop et al., 2005). Loop et al. (2005) concluded that when human T-lymphocytes were exposed to Sevoflurane or Isoflurane, cell apoptosis occurred at an increased rate.

Anesthetic agents, including inhaled and intravenous agents, depress immune cell function, not only by inducing cellular apoptosis, but also by suppression of NK cell activity. (Griffis, Page, Kremer, \& Yermel, 2008). Opioids, a part of the anesthetic plan, have also demonstrated immune suppressive effects in animals (Griffis et al., 2008). They have been found to cause NK cell suppression, lymphocyte proliferation and inflammatory cytokine production (Griffis et al., 2008). The overall result of any anesthetic use on the human body is immunomodulation. Thorough understanding of this anesthetic impact on immune alteration is important for future guidance of anesthetic practice. The evidence has shown numerous ways to deliver anesthesia and techniques 
that may be more effective in susceptible patients (Griffis et al., 2008).

Opioids. Opioids are a common adjuvant to an anesthetic method and are therefore relevant to this review. They act at opioid receptors in the central nervous system (CNS) and in the peripheral system. Their binding facilitates a decrease in neurotransmission by increasing potassium conductance and calcium channel inactivation. This inactivation decreases neurotransmitter (NT) release by binding the opioid to its receptor. Once binding occurs, it results in a suppression of substance $\mathrm{P}$ release, inhibition of adenylate cyclase, and further leads to a reduction in cyclic adenosine monophosphate (cAMP) (Flood, Rathmell, \& Shafer, 2015). Opioids are a large contributor to immunosuppression and are hypothesized to suppress the hypothalamic pituitary adrenal axis (HPA) (Smith \& Vale, 2006). The HPA controls the body's response to stress and regulates immune function. When the HPA is suppressed, the body is at greater risk for invasion. Identified effects of opioids on the immune system include cell suppression, lymphocyte proliferation and inflammatory cytokine production.

Fentanyl, a common synthetic opioid used in the anesthetic medication plan, is another identified cause of immune suppression. Narahara, Kadoi, Hinohara, Kunimoto, and Saito (2013) examined the effects of Fentanyl and Flurbiprofen on NK cells, lymphocytes and cytokines in the post-surgical patient. In a prospective, randomized study that included 25 patients who underwent neck surgery, the same intraoperative anesthetic technique was used consisting of Propofol and Rocuronium. Patients’ anesthetic depth were then maintained with Sevoflurane, Remifentanil and intermittent Fentanyl boluses. Postoperatively, all patients were transferred to the ICU where random 
sedation was maintained with both Propofol and Flurbiprofen $(\mathrm{N})(n=12)$ or Propofol and Fentanyl (F) (n=13). Patients were followed for 48 hours while continuing to receive pain control and sedation with Propofol at $0.5 \mathrm{mg} / \mathrm{kg} / \mathrm{hr}$, which was increased or decreased according to the Richmond Agitation Scoring System (RASS). The Flurbiprofen was dosed at a rate of $0.1 \mathrm{mg} / \mathrm{kg} / \mathrm{hr}$ and was increased by $0.02 \mathrm{mg} / \mathrm{kg} / \mathrm{hr}$ if the behavioral pain scale (BPS) score was greater than 5. Similarly, Fentanyl was dosed at $1 \mathrm{ug} / \mathrm{kg} / \mathrm{hr}$ and increased by $0.2 \mathrm{ug} / \mathrm{kg} / \mathrm{hr}$ for BPS score greater than 5 (Narahara et al., 2013).

Arterial blood samples were obtained from all patients (15 ml) prior to surgery and at the completion of surgery. Blood was collected on postoperative (postop) day (POD) 1 and 2. From each sample, $5 \mathrm{ml}$ of blood was utilized for examination of lymphocytes, $5 \mathrm{ml}$ for NK cells exam and the remaining $5 \mathrm{ml}$ for plasma level evaluation of TNF and IL-6 (Narahara et al., 2013). In the preoperative (preop) evaluation, as well as in the immediate postoperative evaluation, both groups demonstrated similar NK cell levels $\mathrm{N}=40 \%$ and $\mathrm{F}=39 \%$ (preop) $\mathrm{N}=28 \%$ and $\mathrm{F}=22 \%$ (postop). This, however, changed on POD1 and POD2 N=15\% and F=7\% POD1; N=17\% and F=10\% (POD2). Lymphocyte changes (CD3+) of the $\mathrm{N}$ vs. F group averages were $63.4 \%$ vs. $67.3 \%$ (preop), 69.4\% vs. 67.9\% (postop), 61.7\% vs. 56.5\% (POD1), and 67.8\% vs. $64.7 \%$ (POD2). For TNF blood sample evaluation, N vs. F showed plasma concentrations of $0.88 \mathrm{pg} / \mathrm{ml}$ vs. $0.96 \mathrm{pg} / \mathrm{ml}$ (preop), $1.74 \mathrm{pg} / \mathrm{ml}$ vs. $2.02 \mathrm{pg} / \mathrm{ml}$ (postop), $0.80 \mathrm{pg} / \mathrm{ml}$ vs. $1.04 \mathrm{pg} / \mathrm{ml}$ (POD1), and 1.14 pg/ml vs. 1.06 pg/ml (POD2). For IL-6, 3.9 pg/ml vs. 3.1 pg/ml (preop), 478.7 pg/ml vs. 506.9 pg/ml (postop), 44.3 pg/ml vs. 77.2 pg/ml (POD1), and 60.4 pg/ml vs. 60.3 pg/ml (POD2) (Narahara et al., 2013). Narahara et al. (2013) found a large decrease in NK cells on POD1 in the Fentanyl group, indicative of 
immunosuppression. There were minimal differences between groups in relation to cytokine and lymphocyte levels.

Large doses of opioids are used as adjuvants to both general anesthesia and regional anesthesia techniques. Both general anesthesia and regional anesthesia have demonstrated controversial effects on immunomodulation and potentially place susceptible patients at risk for tumor cell metastasis. Two types of anesthesia administration techniques will be further reviewed: general anesthesia (GA) and regional anesthesia (RA), and the different affects each play on the immune system.

General anesthesia. The goal of GA is to obtain and maintain unconsciousness, amnesia, analgesia, and loss of sensory processing and depression of reflexes. General anesthesia can involve the use of many different medications to produce unconsciousness. For example, the volatile anesthetic gases are utilized to maintain a constant state of anesthesia. Whereas, hypnotics, such as Propofol, work in the central nervous system (CNS) by selectively modulating gamma amino butyric acid (GABA) receptors (Flood et al., 2015). Opioids, addressed above, are an adjuvant to GA. Finally, benzodiazepines, another adjuvant to the anesthetic regimen, can be added to a general anesthetic for enhanced effects. Benzodiazepines act on GABA receptors by increasing the affinity of the receptors and causing chloride conductance and hyperpolarization (Flood et al., 2015).

Scavonetto et al. (2014) investigated long-term outcomes for patients with adenocarcinoma of the prostate gland. This retrospective cohort study investigated surgical cases that utilized regional anesthesia with GA, vs. the use of GA only. Scavonetto et al. (2014) hypothesized that the use of neuraxial regional anesthesia in 
patients with adenocarcinoma would have better outcomes with radical prostatectomy than with the use of GA alone, due to the decreased use of large dosed opioids and volatile anesthetics. The authors identified patients who had undergone a radical prostatectomy from January 1991- December 2005. The sample size included 3,284 patients, and a 1:1 ratio was used for the study to evaluate combined regional anesthesia and GA effects vs. the solo general anesthetic. The GA anesthetic regimen included Propofol, Fentanyl, Midazolam and Succinylcholine and a maintenance volatile anesthetic. The neuraxial regional/GA-combined technique utilized a spinal anesthetic dose of $0.5 \%$ bupivacaine with intrathecal morphine, or an epidural with a continuous infusion of bupivacaine $0.125 \%$ and fentanyl $20 \mathrm{mg}$. The patients who received neuraxial adjuvant therapy required less perioperative opioids, if any. The subjects participated in regularly scheduled follow-ups. The median follow-up time frame after the prostatectomy was 8.6 years in the neuraxial regional/GA group and 9.0 years for GA only group. The outcomes and deaths associated with each group were evaluated at 5, 10 and 15 years. For the GA vs. neuraxial regional/GA group, systemic progression of cancer was $1.2 \%$ vs. $0.8 \%$ (5 years), $3.2 \%$ vs. $1.3 \%$ (10 years), and $5.1 \%$ vs. $3.1 \%$ (15 years). The outcomes for cancer recurrence demonstrated return rates of (GA vs. neuraxial regional/GA): $14.7 \%$ vs. $12.8 \%$ (5 years), $22.8 \%$ vs. $20.8 \%$ (10 years), and $29.9 \%$ vs. 25.2\% (15 years). The prostate cancer death the rates of each group was (GA vs. neuraxial regional/GA): $0.6 \%$ vs. $0.3 \%$ (5 years), $1.4 \%$ vs. $0.4 \%$ (10 years), and $4.2 \%$ vs. 2.2\% (15 years) (Scavonetto et al., 2014). Scavonetto et al. (2014) noted that regional anesthesia combined with general anesthesia had less recurrence of prostate cancer compared to the sample that received general anesthesia alone. The supplementation of 
neuraxial regional anesthesia showed a decrease in the use of opioids and volatile anesthetics. A conclusion was made that the decreased use of both volatile anesthetic and opioid use was associated with a decrease in systemic cancer progression and an overall reduced stress response (Scavonetto et al., 2014). Volatile anesthetics are a factor impairing host defenses against cancer through suppression of the NK cells and promotion of immunosuppression.

Volatile anesthetics. Volatile anesthetics, used frequently in general anesthesia, are also demonstrating evidence that they factor into inflammation and survival. Fuentes et al. (2006) investigated the use of Isoflurane and its effect on the reduction of leukocytes in rats, and its ability to function as an anti-inflammatory agent. This experimental study included 10 eight-week-old mice in 2 separate cohorts. The first cohort was injected with a lethal dose of inflammatory lipopolysaccharide (LPS is a membrane component of gram negative bacteria) and then exposed to one hour of $2 \%$ Isoflurane. The second (control) cohort was only injected with LPS. Blood samples were then collected 1-hour after the interventions. Samples showed a reduction in serum TNF of 1,276 pg/ml (LPS/Isoflurane group) vs. 5,249 pg/ml (LPS control group), IL-6 (1,192 pg/ml vs. 27,681pg/ml) and IL-10 (146 pg/ml vs. 1,166 pg/ml) between the LPS/Isoflurane and the LPS only control groups, respectively. After 48 hours, the Isoflurane/LPS mice survivors fully recovered, compared to 80 hours for full recovery in the LPS control mice survivors. After 72 hours, the mice exposed to both Isoflurane and LPS showed survival rates of $85 \%$ compared to the $23 \%$ survival rate of the mice only exposed to the LPS (Fuentes et al., 2006). Fuentes et al. (2006) concluded that 
anesthetics, such as Isoflurane, demonstrate an ability to attenuate the systemic inflammatory response and increase survival times in LPS mice exposed to Isoflurane.

Regional anesthesia. Regional Anesthesia is used to block the sensation of a specific part of the body for a specific procedure. Regional anesthesia includes nerve blockade by spinal, epidural, and peripheral blocks, to name a few. Spinal anesthesia utilizes local anesthetics administered intrathecally to block neuronal sensation. Occasionally, the uses of intrathecal opioids are used as an adjuvant to this technique. Decreases in cancer metastasis are possible with the use of regional anesthesia due to the decrease activation of the human stress response (Heinrich, Janitz, Merkel, Klein, \& Schmidt, 2015). The benefits of regional anesthesia include decreases in the need for opioids perioperatively. The decrease in perceived pain subsequently leads to a decrease in requirements for opioids and therefore an overall reduction of altered immune responses (Heinrich et al., 2015).

Local anesthetics delivered via epidural catheters have shown promise in suppression of tyrosine kinase receptor activity, a critical element for differentiation and proliferation of cancer cells. Tyrosine kinase receptors, in the compromised patient, play a crucial role in cancer development and progression. By suppressing this activity, cancer cell proliferation may also be suppressed. Heinrich et al. (2015) evaluated the short and long-term outcomes of epidural analgesia use in patients with esophageal cancer after abdomino-right thoracic esophagectomy from 1995-2005. This retrospective study included 153 patients, of which 118 received an epidural and 35 did not. All patients received a balanced general anesthetic with $1.5-2 \%$ of Sevoflurane. Postoperative patients with epidural received injections of ropivacaine and patients without an epidural received 
a continuous infusion of opioid analgesia (Heinrich et al., 2015). Heinrich et al. (2015) found that patients who did not receive the epidural had longer ICU stays and additional opioid requirements when compared to the epidural group. However, the investigators noted no significant differences in the recurrence of cancer between the two groups: $27 \%$ no epidural vs. 23\% epidural group. There were no significant differences reported between 1-year or 5-year survival rates (Heinrich et al., 2015). Limitations to the study included epidural catheters were only used in the postoperative period. Intraoperative opioids were utilized and could have impacted the outcomes. Rationales for why epidural catheters were denied in some patients were not discussed and could have had further influence on the study results. The primary benefit of the study was the identification of decreased opioid requirements in the epidural anesthesia group compared to the nonepidural group. This is noteworthy, because the literature (Narahara et al., 2013) has shown that a decreased use of opioids promotes better immune responses in surgical patients and decrease the possibility of immune suppression in susceptible patients.

Local anesthetics are used to block pain sensations within an area of the body. Their mechanism of action involves binding to sites within the voltage-gated channels by blocking sodium and reducing the overall excitability in tissues within the CNS, cardiac or neuronal areas (Flood et al., 2015). Local anesthetics are used to reduce stress on the body during the perioperative phase and have been identified as improving overall patient outcomes and reducing the need for intraoperative medications. The use of regional anesthesia in surgical patients reduces the incidence of cancer recurrence. By weakening the sympathetic nervous system's response during surgical interventions, less opioids are required, and the negative effects associated with opioid use are avoided (Le-Wendling et 
al., 2016). Local anesthetics also have an antitumor and anti-inflammatory property, limiting cancer recurrence chances in high-risk patients (Le-Wendling et al., 2016), therefore possibly making regional anesthesia a preferred method for the oncological patient.

General anesthesia vs. Regional anesthesia. The anesthetic used in all surgical procedures is chosen by the anesthesia provider to deliver the best outcome for the patient. Controversy exists, however, as to what the best anesthetic choice is in relation to type of surgery, and to possible cancer redevelopment. Thus, research has also focused on whether general anesthesia or regional anesthesia provides better long-term patient outcomes. For instance, Exadaktylos et al. (2006) performed a retrospective chart review to evaluate the effects of anesthetics and cancer recurrence in patients who had undergone primary breast cancer surgery. The use of paravertebral anesthesia, a type of regional anesthesia, was compared to general anesthesia and postoperative opioids to evaluate for an association with cancer recurrence. Recurrence was documented in $6 \%$ of the paravertebral group and $24 \%$ in the general anesthesia group. Exadaktylos et al. (2006) also found a slower time to recurrence for the paravertebral group.

Similar research was conducted by Christopherson, James, Tableman, Marshall and Johnson (2008). These investigators designed a retrospective review of long-term survival after colon cancer surgery in relationship to anesthetic technique and the incidence of metastasis. A combination of epidural anesthesia given with general anesthesia vs. only general anesthesia was evaluated. The results demonstrated reduced incidences of death and major complications in patients who received combination epidural anesthesia and GA. Christopherson et al. (2008) reported a decreased incidence 
of myocardial infarctions, respiratory failure, infections, and strokes in patients who received combination epidural anesthesia and GA. Patients without evidence of metastasis survived three times longer than the patients who developed cancer metastasis. Those patients who received GA only were more likely to develop metastasis (44.5\%) than those who received combination epidural anesthesia and GA (28.2\%) (Christopherson et al., 2008).

General anesthesia encompasses many different methods for delivery of a proper anesthetic. Initial anesthetic choices may appear appropriate for individuals, but over time may have consequences. Lai et al. (2012) researched general vs. epidural anesthesia and cancer recurrence in patients with small hepatocellular carcinoma (HCC). This retrospective study evaluated 179 patients with small HCC from August 1999 to December 2008. Of the 179 patients, 108 patients underwent radiofrequency ablation (RFA) under GA and 57 patients underwent RFA with epidural anesthesia (EA) (the remaining were lost due to incomplete ablations or follow-up). The GA group was induced with 1-2 mcg fentanyl and $1 \mathrm{mg} / \mathrm{kg}$ of Propofol and maintained with continuous IV infusion of Propofol at 5-8 mg/kg/hr. Type of volatile anesthetic used was not mentioned. Spontaneous ventilation was maintained throughout the RFA. The EA group received $1.5 \%$ Lidocaine at the thoracic level of $\mathrm{T}$ 8-10 twenty minutes prior to RFA. Postoperatively, both groups were given a transdermal opioid patch of either Fentanyl or Morphine for pain. In postoperative month one, imaging via CT scan or MRI was performed with liver function testing (LFT). Follow-up with imaging and LFTs were continued every two months for 24 months, and then every three months afterwards with chest X-rays performed every six months (Lai et al., 2012). 
Results were classified by imaging results and LFTs. The absence of tissue growth at the tumor site was considered a complete ablation, and conversely the presence of tissue growth at the tumor site was considered an incomplete ablation. Tissue margins of the original tumor were used to identify local recurrence and a new separate lesion within the liver was considered intrahepatic recurrence (Lai et al., 2012). Metastatic lesions outside of the liver defined extrahepatic. Follow-up for patients ended in January 2011. End points for the study included recurrence-free survival (between treatment and date of recurrence or death) and overall survival (between treatment and death or last follow-up). The results showed median follow-up to be 43 months (Lai et al., 2012). Cancer recurrence was detected in 40 patients in the GA group and 50 patients in the EA group. Survival rates for recurrence-free patients of GA vs. EA were $86 \%$ vs. $84 \%$ (1 year), $60 \%$ vs. $40 \%$ (3 years) and 52\% vs. $26 \%$ (5 years). Overall survival showed the EA group had 43 deaths in the follow-up time frame from HHC progression (38 patients), liver failure (4 patients) and other causes (1 patient) (Lai et al., 2012). In the GA group, 41 deaths occurred in the same time frame from HCC progression (40 patients), liver failure (9 patients) and other causes not mentioned (2 patients). The results for estimated overall survival rates at one year were GA (95\%) vs. EA (93\%), at three years were GA (85\%) vs. EA (79\%) and at five years were GA (69\%) vs. EA (53\%) (Lai et al., 2012). These findings suggest that HCC patients who underwent RFA with GA had a decreased risk of cancer recurrence compared those who underwent the same procedure with EA. This study contradicts much of the current evidence available regarding general vs. regional anesthesia. Lai et al. (2012) point out that tumor type may have an impact on recurrence risk related to type of anesthesia. 
As this study was retrospective, it also had limitations, including the need for the use of multivariate Cox regression model, with propensity score, and analysis adjusting for propensity score with inverse probability (Lai et al., 2012). This had to be repeated numerous times and resulted in 3 different HRs on recurrence free survival and 3 different HRs on overall survival. Lai et al. (2012) discuss that anesthetic technique was not randomly assigned and therefore, they could not determine if the analgesia was sufficient. Researchers acknowledge RFA are associated with referred pain, and epidural anesthesia/analgesia may not have covered the referred pain areas, consequently additional opioid administration may have been warranted. Lai et al. (2012) also discuss the impact of GA on systolic blood flow reduction and a consequential decrease in hepatic blood flow that may increase coagulation diameter and impacting liver function markers and may account for the results of this study. Lai et al. (2012) recommended the need for a larger prospective study and that the results of this study should be interpreted cautiously because clear evidence in overall survival was not concluded. Further research is still required for this topic.

Brox, Chan, Cafri, and Inacio (2016), evaluated the use of neuraxial vs. general anesthesia on mortality rate in elderly patients requiring surgery for a hip fracture using a retrospective cohort study. These researchers used a hip fracture registry to identify patients with hip fractures who underwent surgery between January 2009 and December 2012. The sample consisted of 7,585 patients who were between the ages 55-89 years. Anesthetic methods of GA only, neuraxial anesthesia only and GA with neuraxial anesthesia were evaluated for differences. The researchers evaluated post-surgical mortality at day 30, 90, and 365. Of the total, 4,257 patients underwent GA, 260 patients 
underwent neuraxial, and 3,059 patients underwent combined method of GA and neuraxial (Brox et. al, 2016). Within 30 days of surgical intervention, there were 177 (4\%) reported deaths in GA group, 113 (4\%) deaths in the neuraxial anesthesia group, and 17 (6\%) deaths in the combination group. Within 90 days, there were 336 (8\%) deaths from GA group, 224 (7\%) deaths from the neuraxial anesthesia group, and 23 (9\%) deaths in the combined group. By day 365, GA deaths reached 661 (16\%) deaths, neuraxial deaths reached 424 (14\%) and mixed method reached 41 (15\%) deaths (Brox et al., 2016). Brox et al. (2016) reported no significant differences between neuraxial anesthesia and general anesthesia on overall patient mortality. This study implied other variables, such as BMI, age, sex, race, and American Society of Anesthesiologists score (ASA) may have had a larger impact than what was explored. Although this study did not show any benefit of one technique over the other, it supports the need for further investigation into different anesthesia techniques for susceptible populations.

\section{Integrative review purpose}

The purpose of this integrative review was to explore the literature from 2006 present to identify the best anesthetic practice for the oncological surgical patient. All relevant literature was compared to examine the evolution and advances in knowledge of anesthesia's effect on immunomodulation, the alteration of the immune system, and cancer recurrence. By comprehensively reviewing the related literature, a better understanding of existing relationships between anesthetics and the effects on cancer recurrence in the surgical patient can be identified.

Next the theoretical framework used to guide this study is presented. 


\section{Theoretical Framework}

For this integrative review, Whittemore’s Stages of Review framework was used to overcome the challenges associated with locating adequate and reliable studies. This framework allows diverse data sources to be utilized to support the specific issues associated with the overall purpose of this review. Whittemore's stages can be broken down into problem identification stage, literature search stage, data evaluation stage, data analysis stage and presentation stage (Whittemore \& Knafl, 2005). The problem identification stage includes identification of the problem that the review addresses. The desired variables of interest and population should be determined in this stage. Having clear identification of the problem with the correct purpose will provide focus for the review.

The literature search stage starts with adequate search strategies in diverse databases. An adequate search will enhance the rigor and help to prevent bias. All relevant literature should be reviewed for the appropriate problem and topic of interest. All applicable research should be included for evaluation and assessment to further support the review (Whittemore \& Knafl, 2005).

The data evaluation stage aims to assess primary sources located during the literature search. The data analysis will provide organization to the review and synthesis of the research will be included. Research questions will be answered, and an understanding of the problem should become evident. For this integrative review a constant comparison of similar designed studies/research will be used to locate patterns, themes, relationships and variations between sources. The analysis portion of the review will include additional steps including data reduction, display, comparisons and potential 
conclusions (Whittemore \& Knafl, 2005).

The final stage is presentation of the literature. This was done in a diagrammatic form. This stage will show results and evidence of the literature to support the overall purpose and understanding of the review. This stage helps to contribute to an enhanced understanding of the problem of interest (Whittemore \& Knafl, 2005).

Table 1

Whittemore: Stages of Review

\begin{tabular}{|l|l|}
\hline Stage of Review & Decisions and Issues \\
\hline $\begin{array}{l}\text { Problem } \\
\text { Litentification }\end{array}$ & $\begin{array}{l}\text { Initial stage to identify main purpose for review and variables of } \\
\text { interest }\end{array}$ \\
\hline Data Evaluation & To enhance rigor and to identify eligible primary sources \\
\hline Data Analysis & $\begin{array}{l}\text { Use of constant comparison method to itemize studies and } \\
\text { categorize data: includes data reduction, data display and data } \\
\text { comparison }\end{array}$ \\
\hline Presentation & $\begin{array}{l}\text { Conclusions of review in diagrammatic form with logical } \\
\text { evidence }\end{array}$ \\
\hline
\end{tabular}

Next, the methods section is presented. 


\section{Methods}

\section{Purpose}

The purpose of this integrative review was to explore the literature from 2006 present to identify the best anesthetic practice for the oncological surgical patient. All relevant literature was compared in order to examine the evolution and advances in knowledge of anesthesia's effect on immunomodulation, the alteration of the immune system, and cancer recurrence. By comprehensively reviewing the related literature, a better understanding of existing relationships between anesthetics and the effects on cancer recurrence in the surgical patient can be identified.

\section{Search Strategy}

A review of literature from 2006 to present was thoroughly investigated, using both quantitative and qualitative studies, as well as informative literature, to provide depth and evidence to this topic. The adult oncological patient, 18 years and older, was the population of interest for this review. The inclusion criteria used was: literature in the English language, human subjects, adults treated with surgical intervention for a primary cancer and the use of regional and general anesthetics. The search included all cancer types.

\section{Search Criteria}

Exclusion criteria included current metastasis cancer studies prior to anesthetic use, studies examining children, and incomplete retrospective studies. Eight articles were used to provide satisfactory support for this review. 


\section{Data Collection}

One reviewer collected data for this integrative review. Each article was reviewed to identify the inclusion and exclusion criteria for this integrative review. The literature search included the use of key words, and numerous databases. The use of The Integrative Review: Updated Methodology article by Whittemore and Knafl (2005) was used as a guide to help define methodology strategies for integrative reviews in stages. Stage one was to identify a problem within a target population. The second stage included a literature search using keywords, different search strategies and databases. The third stage included data analysis displaying and comparing the data with conclusions and creating generalized concepts. A presentation of findings to disseminate ideas of a given population for a given purpose concluded the final stage in Whittemore and Knafl's guide.

\section{Critical Appraisal}

To evaluate the strength and limits to each study chosen for this review, Polit and Beck’s Guide to a Focused Critique of Evidence Quality in a Qualitative /Quantitative Research Report (Polit \& Beck, 2014) (Table 2) was used to identify whether the evidence in each study was accurate and clinically relevant. Using Polit and Beck’s method, an evaluation and appraisal of quantitative research, qualitative research, and literature reviews was completed.

Next, the results section is presented. 


\section{Results}

Articles chosen for this review were located through electronic searches in PubMed Health, CINAHL and Medline Plus. Key words used to search for the desired articles included; anesthesia and cancer, recurrence, time to recurrence, anesthesia technique, and regional vs. general anesthesia. Initial results from the search using keywords ‘anesthesia and cancer’ yielded 849 articles from CINAHL, 289 articles from PubMed and 511 articles from Medline Health. The search was narrowed by adding keyword 'recurrence' and yielded 120 articles from CINAHL, 131 articles from PubMed Health, and 30 articles from Medline Plus. Adding an additional keyword 'anesthesia technique’ yielded 41 articles from CINAHL, 106 articles from PubMed Health, and 16 articles from Medline Plus further narrowed the search. Duplicate studies found during the search in each database were discarded from the study selection. A final search included the above mentioned inclusion criteria search. Only full text articles were included. The result included a total of 8 articles for the integrative review.

Results for this integrative review will be discussed by earliest date of research. A critique table for each study reviewed is contained in Appendix A. The findings for each reviewed article are provided in Appendix B. A critical analysis of the articles is located in Appendix C.

\section{Anesthetic Use in Oncologic Patients}

Exadaktylos et al. (2006) (Appendix A-1) conducted a retrospective study to investigate the association between anesthetic technique and the recurrence of, or metastasis of breast cancer after surgical intervention. The data was collected from the Mater Misericordiae University Hospital in Dublin, Ireland. The investigators of this 
study examined a total of 129 medical records of breast cancer patients who underwent mastectomies with axillary clearance during September 2001 and December 2002. Two groups were formed; patients who received paravertebral anesthesia and analgesia $(n=50)$ and patients who underwent general anesthesia and received postoperative morphine ( $n=79$ ). Scheduled follow-up occurred at 32 months $+/-5$ months. Exadaktylos et al. (2006) noted no significant differences between the patient’s tumor presentation, prognostic factors, or surgical details. All the patients studied were cared for by the same surgeon. The primary outcome measured was the incidence of cancer recurrence or metastatic spread through August 2005. The sample size was unequal, and small, which can be noted as a limitation to this study. Inclusion and exclusion criteria were clearly defined. The method of data analysis was addressed by the authors in both narrative and table format.

The findings are presented in Appendix B-1. Exadaktylos et al. (2006) noted recurrence or metastasis documented in 3 out of 50 Paravertebral Block (PVB) patients (6\%) and 19 out of 79 GA patients (24\%). PVB showed slower times to recurrence ( $p=$ 0.013). PVB risk of recurrence was significantly less $(p=0.012)$, HR 0.21 compared to the GA group. The authors concluded that using PVB for breast cancer surgical patients reduced the risk of recurrence or metastasis. Exadaktylos et al. (2006) reported that regional anesthesia may play an important role in preserving immune function during surgical intervention. This technique is thought to decrease the GA and opioid requirements known to suppress the immune system, and thus reduce the risk of tumor metastasis and/or recurrence. 
Biki, et al. (2008) (Appendix A-2) conducted a retrospective analysis on anesthetic technique for radical prostatectomy surgery and its effects on cancer recurrence. Data was collected at the Mater Misericordiae University Hospital in Dublin, Ireland. Only records of patients with invasive prostatic carcinoma who underwent an open radical prostatectomy during January 1994 and December 2003 were included in the review. The patients were evaluated until October 2006. Biki, et al. (2008) provided a clear statement of the purpose with an informative literature review. The purpose of the study was to identify the risk of prostate cancer recurrence in patients who received either epidural anesthesia/analgesia with general anesthesia or general anesthesia with opioid analgesia. The hypothesis was clearly written, stating that the recurrence of prostate cancer is less common using a combined general anesthesia and epidural analgesia rather than with general anesthesia alone. The endpoint for data collection included evaluating biochemical recurrence in the postoperative phase. Biochemical recurrence, also referred to as an increase in prostate specific antigen (PSA), is indicative of cancer recurrence or metastatic spread (Biki, et al., 2008). Biki et al. (2008) also evaluated recurrence free time, which was defined as the time between surgery data and last PSA. The sample size included 103 patients in the group who received general anesthesia (GA) along with opioids, and 102 patients in the epidural-general anesthesia (EA) group. Limitations included failed epidurals and opioid administration to epidural recipients due to failed epidurals. The patients of the epidural group had higher ASA scores, more complications and shorter surgeries.

Findings (Appendix B-2) demonstrated that the EA group had higher ASA scores (III) compared to the GA group at 8 patients to 3 patients $(p=0.11)$, and shorter 
surgeries $(1.8+/-0.4$ hours vs. $2.0+/-0.5$ hours) $(p=0.06)$ (Biki et al., 2008). The EA group was noted to have more postoperative complications, including pneumonia, postoperative bleeding and other respiratory issues (Biki et al., 2008). Patients who received EA had a decreased estimated risk of recurrence compared to that of the GA group, with a hazard ratio (HR) of: 0.34, 95\% CI = [0.19-0.61]. A Gleason score, used to evaluate the prognosis of prostate cancer, showed $6.1 \%$ for general anesthesia vs. $5.9 \%$ for epidural/general anesthesia $(p=0.42)$. The higher the Gleason score, the more likely for cancer spread. In the univariate analysis, the Cox Regression HR for the Gleason score was 1.53, 95\% CI = [1.29-1.80], $(p=0.001)$, preoperative PSA HR 1.01, 95\% CI = [1.00-1.03], the size of the tumor HR 1.25, 95\% CI = [1.13-1.38], and length of surgery HR 1.79, 95\% CI = [1.09-2.92] were noted to have relation with recurrence. After adjustments were made for the above variables, EA had a lower risk for recurrence compared to GA with a HR 57\%, 95\% CI = [17-78\%]. The authors also used propensity matched analysis and found similar results, which indicated that patients who received EA were $52 \%$ less likely to have recurrence compared to that of the GA patients (univariable HR 0.48, 95\% CI = [0.23-1.00], $(p=0.049)$ ). Sensitivity analysis was also used to account for potential bias due to loss of follow-up after four years. Each anesthetic type reviewed against recurrence for the first 3 years showed univariable ( $p=$ $0.012)$ and multivariable $(p=0.033)$ results. A limitation of this study was that it was a non-randomized, retrospective, observational design. This study was also limited because non-standardized clinical care was delivered, and there were imprecise data analyses due to wide CI's. Biki, et al. (2008) also noted that possible selection bias, and unmeasured confounding variables, could not be dismissed as limitations. The authors acknowledged 
similar results in a previous report in women who underwent breast cancer surgical intervention and discussed the need for an estimated effect size for larger randomized control trials.

Lin et al. (2011) (Appendix A-3) conducted a retrospective review of medical records of women who underwent surgical interventions for ovarian serous adenocarcinomas. The records reviewed were from 1994 to 2006 for those who underwent the use of general anesthesia (GA) or epidural (regional) anesthesia (EA). Data was collected at the Sun Yat-sen University Cancer Center. One hundred and fortythree medical records of patients who underwent surgical intervention for ovarian serous adenocarcinoma were reviewed. Survival rates in 106 patients who underwent EA with analgesia and 37 who underwent GA with opioid analgesia, were evaluated over 2-14 years. The primary outcome measured in this study was death rate by survival analysis (Lin et. al, 2011) (Appendix B-3). The EA group was found to have shorter surgeries 3.3 hours vs. 3.5 hours in the GA group ( $p=0.06$ ), and better International Federation of Gynecology and Obstetrics (FIGO) staging (2.3 vs. 2.9 respectively). The EA group, however, had more complications including: postoperative bleeding, pneumonia, respiratory tract infections and urinary tract infections $(p=0.07)$. The 3-yr. and 5-yr. overall survival rates for the EA group were 78\% and 61\%, and for the GA group, 58\% and $49 \%$, respectively. Both groups had attrition due to lack of follow up. Results suggest patients who underwent surgical intervention for ovarian serous adenocarcinoma with EA had better survival outcomes than GA patients.

Lin et al. (2011) recognized two factors that may account for the results of the study. First, the immunosuppressive effects of general anesthesia were not present in the 
epidural group. Secondly, the doses of opioids used in the epidural group were 10x lower than the general anesthesia group. Lin et al. (2011) stated that these two factors may have led to a reduced suppression of the NK cell activity, and thus prevented tumor spreading. Several limitations are identified in this study including; patient selection was not random, small, uneven sample size and the lack of standardized patient care. Due to these limits, effects of unmeasured confounding variables and selection bias cannot be excluded. The report did not address the issue of generalizability but did address the need for a large prospective randomized control trial to further support the impact of anesthesia technique on ovarian serous adenocarcinomas.

Cummings, Xu, Cummings, and Cooper (2012) (Appendix A-4) compared epidural/analgesia and traditional pain management on cancer recurrence and survival after colectomy for colon cancer. The data were collected from the Surveillance, Epidemiology, and End Results (SEER) Medicare data base, which was used to compare overall survival and cancer recurrence of patients who did/did not receive epidural anesthesia and/or analgesia for resection of non-metastatic colorectal cancer. Cummings et al. (2012) provided a clear statement of purpose and included a thorough and comprehensive literature review to build a strong basis of study. The purpose of the study was to compare cancer recurrence and survival in colorectal cancer patients who received epidurals and those who did not. The study included a clear hypothesis that epidural anesthesia and/or analgesia is associated with reduced cancer recurrence and improved mortality after colorectal cancer resection surgery. The methods included data collected from the Medicare-SEER database which is approved by the Case Comprehensive Cancer Center Institutional Review Board. The study included a cohort of patients aged 
66 years or older who were diagnosed with incident nonmetastatic colorectal adenocarcinoma and underwent colectomy surgery between 1996 and 2006. The cohort population was chosen after several exclusions were made including; prior diagnosis of cancer and a history of inflammatory bowel disease. From this, two cohorts were defined that became the basis of the study. Criteria for inclusion in the primary cohort were: patients who were enrolled in Medicare within 1 year before cancer diagnosis, until 8 months after diagnosis, or death. This primary cohort focused on overall survival after surgery. The second cohort, or recurrence cohort, focused on recurrence of cancer. The inclusion criteria for the recurrence cohort were: patients who were enrolled in Medicare within 1 year before cancer diagnosis until 4 years after diagnosis, or death who survived at least 12 months after surgery. Data for the primary cohort was ultimately collected from 42,151 patients, of whom $22.9 \%(9,670)$ had epidurals. Data for the recurrence cohort was collected from 40,377 patients, of whom $23.0 \%(9,278)$ had epidurals at the time of recurrence (Cummings et al., 2012).

The findings (Appendix B-4) indicated that for the primary cohort, 5-yr overall survival was 61\% (epidural group) and 56\% (traditional pain management group). The median survival was 7.24 years (yrs.) $(95 \% \mathrm{CI}=[6.96,7.51])($ Epidural group) and 6.09 yrs. (95\% CI $=[5.97,7.51]$ (non-epidural group). For the recurrence cohort, the overall 4yr cancer recurrence was $14.3 \%$ in the epidural group and $13.8 \%$ in the non-epidural group. In the unadjusted logistic regression, an association existed between epidural use and increased cancer recurrence with an (odds ratio $=1.14,95 \% \mathrm{CI}=[1.05,1.24], p=$ 0.002). Adjusting for demographic and clinical covariates, no significant differences were noted in the odds of recurrence between the groups, (odds ratio $=1.05,95 \% \mathrm{CI}=[0.95$, 
1.15], $p=0.28$ ). Cummings et al. (2012) found recipients of blood transfusions showed a significant relation to cancer recurrence in the adjusted model with an (odds ratio $=1.14$, $95 \% \mathrm{CI}=[1.03,1.25], p=0.01)$. The difference in survival rates in the primary cohort that had epidurals, compared to those who did not, suggested that epidural use may be a preferable solution to pain management. Cummings et al. (2012) identified epidural use to be associated with improved survival rates in the colorectal cancer patient who underwent resection, but no significant relationship was made between epidural use and a reduction in cancer recurrence.

Chen and Miao (2013) (Appendix A-5) conducted a meta-analysis on the effects of anesthetic technique and survival in human cancers. Data were collected from the Web of Science database, PubMed, and Medline. The authors provided a clear statement of the purpose, and there was a brief literature review provided. The purpose of the analysis was to test the hypothesis that surgical cancer patients who underwent surgical intervention under EA would have better outcomes than those who underwent surgical intervention under general anesthesia. A hypothesis was included in the study which stated, epidural anesthesia/analgesia combined with or without general anesthesia may be associated with a decrease in cancer recurrence and improved survival after oncological surgery. The method included a meta-analysis of 14 articles. The analysis investigated recurrence free survival (RFS- from day of surgery to first disease relapse from primary cancer) and overall survival (OS- from day of surgery until death). The total numbers of epidural anesthesia cases were 12,000 and general anesthesia cases were 35,000. For OS, 7 studies were included, with 4 studies finding a positive relationship between EA and improved OS. The outcome measure of RFS included 11 studies with numerous cancer types (Chen 
\& Miao, 2013). Out of the 11 studies, 4 studies showed a positive relation between improved RFS and EA (Chen \& Miao, 2013).

The results of the study are summarized in Appendix B-5. Chen and Miao (2013) identified heterogeneity significance in the hazard ratio (HR) for OS: HR $0.8495 \% \mathrm{CI}=$ [0.74 to 0.96$]$. The random effects model was used to analyze data to identify if a favorable relationship exists between OS and EA vs. OS and GA $(\mathrm{HR}=0.84,95 \% \mathrm{CI}=$ [0.74-0.96], $p=0.013$ ). The authors identified a positive association between OS and EA in the five colorectal cancer studies $(\mathrm{HR}=0.65,95 \% \mathrm{CI}=[0.43-0.99], p=0.045)$ included in this review; however, there was no significant association noted between RFS and $\mathrm{EA}(\mathrm{HR}=0.88,95 \% \mathrm{CI}=[0.64-1.22], p=0.457)$ in any of the studies reviewed. The use of regional anesthesia (RA) has been linked to a reduction of surgical stress response stimulation and decreased pain experience. With a decrease in pain, less opioids are required, and immune suppression effects are evaded. (Chen \& Miao, 2013). This metaanalysis suggested a positive relationship between the use of epidural anesthesia/analgesia and improved overall survival in patients undergoing colorectal cancer surgery. Chen and Miao (2013) stated that although this review was unable to support a relationship between epidural anesthesia and cancer control, it did offer some support of the use of RA techniques. The authors did acknowledge the need for further prospective studies to determine a causative association between survival and epidural use.

Jang et al. (2016) (Appendix A-6) conducted a retrospective review of anesthetic technique effects on 5-year survival, and cancer recurrence rates, after transurethral resection for bladder tumors. The data was collected from the Chungnam National 
University Hospital, Daejeon, Korea. The authors provided a clear statement of the purpose and included a brief review of the relevant literature. Jang et al. (2016) collected data to determine if mortality after bladder cancer differed between patients who underwent surgical intervention under GA vs. surgical intervention with RA. The methods utilized for this study made appropriate connections between anesthetics and patient outcomes. For the induction of general anesthesia, Propofol or Etomidate was used with Vecuronium or Rocuronium and Sevoflurane or Isoflurane to maintain the anesthetic depth. Ketorolac was given intravenously for postoperative pain control. For the RA, lidocaine and $0.75 \%$ bupivacaine were used. No analgesics were given to patients in the regional group for postoperative pain. The sample size was $(n=137)$ patients who received RA and $(n=24)$ who received GA. The authors examined the 5year recurrence rate, and recurrence free time, after surgical interventions.

The results of the study are summarized in Appendix B-6. The length of anesthesia time was longer in the general group by 23 minutes. Patients who underwent surgical intervention with RA showed higher recurrence rate $(0.9 \%+/ 1.4)$ compared to the GA group $(0.5 \%+/-0.8)$ during the 5-year follow-up period (Jang et al., 2016). The recurrence free time was noted to be 45 +/- 22 months for the GA group and 40 +/- 24 months for the RA. A normal distribution was not shown; therefore, the Kruskal-Wallis test was used. For the GA group, 73 was the mean rank of recurrence and for RA group, mean rank of recurrence was $82(p=0.28)$, demonstrating no statistically significant differences between the two groups. The Chi-square test of five-year survival was also used. For the GA group, 5-year survival was $87.5 \%$ and for RA it was $96.3 \%$. Jang et al. (2016) further explored logistic regression analysis to examine survival rates. After 
variable consideration, age was found to the primary contributor to a shorter 5-year survival after surgical intervention. To further evaluate age as a primary contributor to shorter 5-year survival, Spearman Rho correlation analysis was performed. A significant, positive correlation was made with age and recurrence $\left(r_{s}=0.168, p=0.033\right)$, in addition to a significant, negative correlation between age and survival $\left(r_{s}=-0.272, p=0.000\right)$. This indicated that younger patients demonstrated longer recurrence free times and greater survival time (Jang et al., 2016). The length of anesthesia time displayed a positive relationship, through partial correlation analysis, with recurrence (coefficient $=$ 0.188, $p=0.017$ ). This corresponded to the finding of a positive association between longer length of anesthesia time and shorter recurrence free time (coefficient $=-0.169, p$ $=0.032$ ). Partial correlation analysis was the only identifier of a true significant relationship between a better 5-year survival and use of RA (coefficient $=-0.167, p=$ 0.044) (Jang et al., 2016). Numerous limitations were identified in this study. These included: small, unequal sample sizes, a lack of randomization, a lack of uniform care, different anesthesia time lengths and age variations between groups. Jang et al., (2016) suggested a larger prospective study be performed with random allocation to support one technique over the other.

Cho et al. (2017) (Appendix A-7) conducted a randomized prospective study to explore the effects of perioperative anesthesia and analgesia on the immune function of breast cancer patients undergoing resection. Data were collected at the Severance Hospital, Yonsei University Health System in Seoul, Korea. Cho et al. (2017) provided a clear purpose and literature review for the study. The purpose of the review was to compare the effects two different anesthetic techniques on Natural Killer cell counts in 
patients with breast cancer undergoing surgical intervention. Researchers clearly hypothesized that avoiding volatile anesthetics and opioid analgesics might lessen immunosuppressive effects during perioperative periods. Fifty patients undergoing breast cancer resection were included in the study. Patients were randomly assigned into two groups; the first group of 25 patients received both Propofol and Remifentanil anesthesia with postoperative Ketorolac (P-R-K), and the second group of 25 patients received Sevoflurane and Remifentanil anesthesia with postop Fentanyl (S-R-F) analgesia. Cho et al. (2017) explored pain scores and inflammatory marker presence preoperatively and again, 24-hours postoperatively. The incidence of cancer recurrence/metastasis was then evaluated every 6 months for 2 years following surgical interventions.

Cho et al. (2017) (Appendix B-7) found an increase in NK cell counts in the P-RK groups and a decrease in NKCC in the S-R-F group postoperatively. The findings suggest that S-R-F induced a more suppressive effect on lymphocytes compared to P-RK. Pain scores were comparable between the two groups 48 hours postop. One patient in S-R-F group showed recurrence in the contralateral breast and no recurrence or metastasis were found in the P-R-K group. The study concluded that there was a more favorable impact on immune function from the P-R-K group with the preservation of NKCC. Limits to the study included: non-blinded operating staff to the group allocation; however, follow-up staff were unaware of patient group involvement when assessing for pain. The use of Remifentanil and Tramadol for a control was used, and their impact on NKCC cannot be excluded. Cho et al. (2017) identified the use of combination drug groups and acknowledged the differences between the groups may be due to combination effects. Cho et al. (2017) pointed out that cancer metastasis within two years after surgery 
did not occur in the study, and further evaluation of long-term outcomes are needed to make further conclusions about cancer recurrence or metastasis.

Perez-Gonzalez, Cuellar-Guzman, Soliz and Cata (2017) (Appendix A-8)

conducted a systematic review of literature regarding the impact of regional anesthesia on the recurrence/metastasis and the immune response in the breast cancer patient after surgical intervention. Perez-Gonzalez et al. (2017) used PubMed, EMBASE, MEDLINE, and Cochrane Trials Registers to perform the literature search of data from 2005-2017. Perez-Gonzales et al. (2017) hypothesized that the use of regional anesthesia was associated with better long-term outcomes after breast cancer surgical intervention. PRISMA was used for reporting, with a total of 467 pertinent studies initially located. Through screening and inclusion criteria methods, a final total of 15 studies were analyzed. To evaluate the methodological quality of the randomized control trials and observational retrospective studies, Perez-Gonzalez et al. (2017) used the NewcastleOttawa scale and Jadad score. Outcome measures studied were broken into three categories to assess the impact of paravertebral blockade: (1) recurrence and survival, (2) humoral response and (3) cellular immune response.

Perez-Gonzalez et al. (2017) identified 6 studies that explored the association of regional PVB/GA anesthesia and GA with volatile gases and opioid analgesia on overall survival and recurrence rates (Appendix B-8). All but 1 of the 6 studies were retrospective and included sample sizes ranging from 60 to 1107 patients. The only RCT included, by Finn et al. (2017), showed no difference in rate of recurrence between PVB vs. GA. A retrospective study by Exadaktylos et al. (2006), however, found a beneficial effect of PVB on lower rate of recurrence, with a recurrence rate of $24 \%$ for the GA 
group vs. $6 \%$ for the PVB/propofol group HR $0.21(p=0.012)$. Yet another of the 5 retrospective studies found a negative impact of PVB on cancer recurrence (Cata et al., 2016). Median follow-up times were recorded at 5.8-6 yrs., and Cata et al. (2016) identified that the use of fentanyl was lower in the PVB group (122.8 +/- 77.8 ug) vs. the non PVB group, (402.23 +/- 343.8 ug). No association of changes in overall survival or recurrence free survival were identified (Perez-Gonzales et al., 2017). Perez-Gonzalez et al. (2017) identified that the remaining retrospective studies did not find any association between PVB and a reduction in rate of cancer recurrence or longer cancer- related survival time (Kairalumoma, Mattson, Heikkila, Pere, \& Leidenius, 2016; Tsigonis et al., 2016; Starnes-Ott, Goravanchi, \& Meininger, 2015).

Four RCTs (Deegan et al., 2010; Looney, Doran, \& Buggy, 2010; O’Riain, Buggy, Kerin, Watson, \& Moriarty, 2005; Sultan, 2013), evaluated in this systematic review explored the impact of PVB on inflammatory biomarkers (Perez-Gonzalez et al., 2017). The effect of PVB/Propofol vs. GA showed minimal to no difference in inflammatory biomarkers and markers of stress response between regional and general anesthesia. Two studies (Looney et al., 2010; O’Riain et al., 2005) examined growth factor (GF) concentrations and effects of angiogenesis/proliferation in the PVB/propofol group and the GA group. Perez-Gonzalez et al. (2017) stated that neither of these studies (Looney et al., 2010; O’Riain et al., 2005) identified that the type of anesthesia given had any impact on concentrations of GF growth factor in the postoperative period. Two studies identified women who received GA showed significant decrease in NK cell function and count (Ramirez et al., 2015; Woo et al., 2015). Perez-Gonzalez et al. (2017) concluded that regional anesthesia could amend the suppressive effects of surgery on 
human cells from avoiding harmful volatile anesthetics and opioids. Three studies (Deegan et al., 2010; O’Riain et al., 2005; Sultan, 2013), which focused on inflammatory mediators and surgical stress, demonstrated insignificant differences in markers of inflammation and stress response between regional and general anesthesia (PerezGonzalez et al., 2017).

Perez-Gonzalez et al. (2017) reviewed 4 RCTs (Buckley, McQuaid, Johnson, \& Buggy, 2014; Deegan et al., 2009; Desmond, McCormack, Mulligan, Stokes, \& Buggy, 2015; Jaura, Flood, Gallagher, \& Buggy, 2014) that investigated the impact of PVB on immune response and cancer cell function. A study by Deegan et al. (2009) showed reduction in breast cancer cells in the PVB/propofol group, while Desmond et al. (2015) showed an increase in NK cells and T-helper cells to breast cancer tissue in the PVB/propofol group. Buckley et al. (2014) showed the PVB/propofol group preserved NK activity, whereas Jaura et al. (2014) showed cancer cell apoptosis was reduced in the GA group, but that cancer cell viability was mutually the same in both groups. Women who received GA in these four studies (Buckley et al., 2014; Deegan et al., 2009; Desmond et al., 2015; Jaura et al., 2014) showed a significant decrease in NK cell function and count. A conclusion was made stating regional anesthesia could ameliorate the suppressive effects from surgical impacts, volatile anesthetic impact and opioid impact on these cells. Two studies involving anesthetic effect during breast cancer surgery on proliferation and apoptosis of cells showed antiapoptotic effects from women who received a GA and inhibition of cell proliferation after exposure to PVB (Deegan et al., 2010; Jaura et al., 2014). Buckley et al. (2014) and Desmond et al. (2015) showed that after mastectomy surgery, women who received PVB anesthesia demonstrated NK 
cell preservation vs. women in the GA group (Perez-Gonzalez et al., 2017).

This review by Perez-Gonzalez et al. (2017) found a low level of supportive evidence of the impact of RA on survival outcomes after surgical intervention for breast cancer. Perez-Gonzalez et al. (2017) identified only one of the RCTs positively tested the hypothesis: PVB reduced the rate of recurrence after breast cancer surgery. This review further identified significant limits including: the retrospective designs, various statistical analysis, selection bias, heterogeneity in type of anesthesia technique used, and lack of detailed information on tumor description including size, stage, and adjuvant treatments (chemo/radiation). Perez-Gonzalez et al. (2017) concluded that there was a lack of persuasive data to support, or contest, a positive association between regional PVB and a reduction in cancer recurrence and improved overall survival rates. The data does, however, support PVB's effect on decreasing the inflammatory response and it may prevent immune suppression during surgery. The authors identified the need for future large RCTs to further explore the anti-inflammatory effects of PVB and propofol as a combination to prevent immune suppression (Perez-Gonzalez et al., 2017).

\section{Cross Study Analysis}

In this portion of the integrative review, a cross analysis of the included studies is presented. Appendix C illustrates findings and themes in each study. The risk of recurrence was a main outcome examined in this review. Biki et al. (2008), Chen and Miao, (2013), Cummings et al. (2012), Exadaktylos et al. (2006), Jang et al. (2016), and Perez-Gonzalez et al. (2017) all examined recurrence risk, and/or time to recurrence, in cancer patients after surgical intervention. The use of regional anesthesia as an adjuvant or a substitute for general anesthesia was found to decrease the risk of recurrence in 2 out 
of the 6 studies (Biki et al., 2008; Exadaktylos et al., 2006). Jang et al. (2016) had found general anesthesia to have a longer recurrence free time compared to epidural anesthesia but did not show a normal distribution or statistical significance after the Kruskal-Wallis test was performed. The definition of recurrence free time was not uniform in any of the cancer recurrence studies (Biki et al., 2008; Chen \& Miao, 2013; Cummings et al., 2012; Exadaktylos et al., 2006; Jang et al., 2016; Perez-Gonzalez et al., 2017).

The next outcome investigated was the 3 or 5 - yr. survival time for post-surgical patients. Five out of the 8 studies examined the survival times in the oncological surgical patient after either regional anesthesia or general anesthesia use (Chen \& Miao, 2013; Cummings et al., 2012; Jang et al., 2016; Lin et al., 2011; Perez-Gonzalez et al., 2017). Significance was found between regional anesthesia use and increased survival in all studies (Chen \& Miao, 2013; Cummings et al., 2012; Jang et al., 2016; Lin et al., 2011) except Perez-Gonzalez et al. (2017). Perez-Gonzalez et al. (2017) found no supportive data that the use of PVB showed any improvement in overall cancer-related survival. Perez-Gonzalez et al. (2017) did identify the use of PVB on improved immune responses in patients compared to those who underwent general anesthesia.

The effect of regional anesthesia vs. general anesthesia on the immune system of the oncological patient after surgical intervention was investigated in 8 of the studies. Cho et al., (2017) and Perez-Gonzalez et al. (2017) examined the impact of anesthesia technique on the immune system and both found the use of propofol to have beneficial effects on NK cell preservation.

Age had a correlation with survival in several studies (Cummings et al., 2012; Jang et al., 2016). Cummings et al. (2012) noted after logistic regression analysis that 
increasing age had an association with a lower risk of cancer recurrence. Jang et al. (2016) identified older age as an independent factor to a reduced 5-yr. survival. Smoking was identified as a contributor to bladder cancer but did not have significant impact on 5yr. survival or recurrence rates (Jang et al., 2016). Anesthesia time showed a positive correlation with recurrence and/or survival time (Biki et al., 2008; Jang et al., 2016; Lin 2011).

Many limits were noted in each study. Retrospective, non-randomized studies were a primary limit noted by authors (Biki et al., 2008; Exadaktylos et al., 2006; Lin et al., 2011) and non-standardized care was another common limit (Chen \& Miao, 2013; Cummings et al., 2012; Exadaktylos et al., 2006; Jang et al., 2016; Lin et al., 2011; PerezGonzalez et al., 2017). The inability to identify respective effects of independent drugs on survival time, recurrence and immune alteration is a limit across all studies. Final conclusions were made by numerous authors that the need for large, randomized, prospective studies is needed to identify association of regional anesthesia on recurrence (Biki et al., 2008; Chen \& Miao, 2013; Cummings et al., 2012; Exadaktylos et al., 2006; Jang et al., 2016; Perez-Gonzalez et al., 2017), and overall survival (Chen \& Miao, 2013; Cummings et al., 2012; Jang et al., 2016; Lin et al., 2011; Perez-Gonzalez et al., 2017). Future studies on methods to alleviate immunosuppression in surgery for cancer patients is warranted (Cho et al., 2017).

Next, the summary and conclusions will be presented. 


\section{Summary and Conclusions}

Anesthesia is an essential piece of the surgical care plan. The wide variety of techniques used for surgery allows for individualized care plans to promote the best possible outcomes for susceptible cancer patients. Evidence regarding cell modulation and immune inhibition in humans after exposure to regional anesthesia and/or general anesthesia has been explored. With the substantial amount of research on the anesthetic techniques for oncological patients, evidence on best practice is not clearly defined or unanimous amongst all studies. All relevant literature was compared to examine the evolution and advances in research related to anesthesia's effect on immunomodulation and cancer recurrence. By comprehensively reviewing the related literature, a better understanding of existing relationships between anesthetics and the effects on cancer recurrence in the surgical patient was identified.

Whittemore and Knafl's, (2005) modified integrative review framework was used to guide this review. A literature review was carried out which explored the impact of anesthesia on the immune system and its effects on survival and recurrence in susceptible primary cancer patients. Following the literature review, a detailed search of relevant studies on anesthesia and its impact on cancer patients after surgical interventions were explored. Search strategies and key words are located in the methods section. All studies used for this project are reviewed in the results section.

Exadaktylos et al. (2006) conducted a retrospective study to investigate the association between anesthetic technique and the recurrence or metastasis of breast cancer after surgical intervention. Two groups were formed: patients who received paravertebral anesthesia and analgesia $(n=50)$ and patients who underwent general 
anesthesia and received postoperative morphine $(n=79)$. The authors noted no significant differences between the patients regarding tumor presentation, prognostic factors, or surgical details. Exadaktylos et al. (2006) identified that using PVB for breast cancer surgical patients reduced the risk of recurrence or metastasis. Exadaktylos et al. (2006) reported that regional anesthesia may play an important role in preserving immune function during surgical intervention. This technique is thought to decrease the GA and opioid requirements that are known to suppress the immune system, and thus reduce the risk of tumor metastasis and/or recurrence.

Biki et al. (2008) conducted a retrospective study to investigate anesthetic technique for radical prostatectomy surgery. The endpoint for data collection included evaluating elevation in PSA in the postoperative phase and recurrence free time, after receiving either a combined general anesthesia and epidural analgesia or general anesthesia with traditional opioid analgesia. Biki et al. (2008) concluded that substituting epidural analgesia for postoperative opioids was associated with less risk of elevated PSA levels and cancer recurrence.

Lin et al. (2011) conducted a retrospective review of women who underwent surgical interventions for ovarian serous adenocarcinomas from 1994 to 2006 under the use of general anesthesia (GA) versus epidural anesthesia (EA). The primary outcome measured in this study was death rate by survival analysis. Results suggested that patients who underwent surgical intervention for ovarian serous adenocarcinoma with EA had better survival outcomes than GA patients due to the lack of immunosuppression from preserved NK cell activity and the decreased use of opioids in the epidural group.

Cummings et al. (2012) conducted a population-based study and compared 
epidural/analgesia and traditional pain management on cancer recurrence and survival after colectomy for colon cancer. Cummings et al. (2012) found recipients of blood transfusions showed a significant relation to cancer recurrence. The difference in survival rates between cohorts suggests that epidural use may be a preferable solution to pain management. Cummings et al. (2012) identified epidural use to be associated with improved survival rates in the colorectal cancer patient who underwent resection, but no significant relationship was made between epidural use and a reduction in cancer recurrence.

Chen and Miao (2013) conducted a meta-analysis on the effects of anesthetic technique and survival in human cancers. Patients with cancer who underwent surgical intervention under epidural anesthesia (EA) vs. general anesthesia were evaluated. The primary outcome measures included recurrence free survival (RFS- from day of surgery to first disease relapse from primary cancer) and overall survival (OS- from day of surgery until death). Chen and Miao (2013) identified a positive association between OS and EA in the colorectal cancer patient. The analysis proposed that epidural anesthesia/analgesia may be associated with improved overall survival but did not support an association between cancer control and epidural anesthesia.

Jang et al. (2016) conducted a retrospective review of anesthetic technique effect on 5-year survival and cancer recurrence rates after transurethral resection for bladder tumors. The primary measure outcome was to identify which anesthetic approach had better overall cancer outcomes measuring 5-year recurrence and overall recurrence free time. Jang et al. (2016) found that 5-year survival was higher in patients whose surgery was completed with regional anesthesia compared to general anesthesia through partial 
correlation. However, significance was not found using the chi-square test and logistic regression.

Cho et al. (2017) conducted a randomized prospective study to explore the effects of perioperative anesthesia and analgesia on the immune function of breast cancer patients undergoing resection. Primary outcome measures included the effects of two different anesthesia and analgesia methods on NK cell cytotoxicity (NKCC) in patients undergoing breast cancer surgery. Cho et al. (2017) found an increase in NK cell counts in the P-R-K groups and a decrease in NKCC in the S-R-F group postoperatively. Cho et al. (2017) concluded that Propofol anesthesia with Ketorolac showed a positive impact on immune function by preservation of NK cell counts compared to Sevoflurane and Fentanyl.

Perez-Gonzalez et al. (2017) conducted a systematic review of literature on the impact of regional anesthesia on the recurrence/metastasis and the immune response in the breast cancer patient after surgical intervention. Perez-Gonzalez et al. (2017) found insufficient data to support or contest the use of a PVB in decreasing cancer recurrence or increasing cancer survival rates. However, a reduction in inflammation and improved immune responses were noted in the PVB group compared to the general anesthesia group.

This review has identified a positive relationship between the use of epidural anesthesia and decreased cancer recurrence in 2 out of the 8 studies (Biki et al., 2008; Exadaktylos et al., 2006). Three out of the 8 studies found increased overall survival rates with the use of regional anesthesia versus general anesthesia (Chen and Miao, 2013; Cummings et al., 2012; Lin et al., 2011). Two of the 8 studies found no associations 
between decreased cancer recurrences or increased overall survival with regional anesthesia versus general anesthesia (Jang et al., 2016; Perez-Gonzalez et al., 2017). Two studies identified preservation of NK cells and decreased immunosuppression with epidural use (Cho et al., 2017; Lin et al., 2011).

This review has identified marginal evidence that regional anesthesia, when compared to general anesthesia, promotes better long-term outcomes for the oncological surgical patient. This review has several limitations which must be acknowledged. The addition of opioid analgesia to numerous regional anesthesia regimens has a known effect on immune suppression and may have had a substantial impact on the outcomes of the studies. The studies included are mostly retrospective and the authors of all the above studies have identified the need for larger prospective randomized control studies to be performed to identify significant evidence of the proposed hypothesis that regional anesthesia is better suited for the vulnerable patient in preserving immune function and preventing cancer recurrence/metastasis.

In conclusion, anesthetic agents and opioids can alter the systemic inflammatory response during surgical interventions. By modulating the immunologic mechanism within the body, direct effects on tumor growth rate and recurrence rate are possible. By impairing cellular immunity and blocking the body's natural fighting mechanisms, accelerated cell growth and cancer recurrence becomes possible. The use of regional anesthesia during surgical interventions has shown the ability to minimize the stress response, preserve NK cell defenses, provide an anticancer immunity, decrease cancer recurrence rates and improve overall cancer survival. Extensive research is still required to show the positive relationship between regional techniques and cancer survival. 
Next, the recommendations and implications for advanced nursing practice is presented. 


\section{Recommendations and Implications for Advanced Nursing Practice}

Evidence-based research affords practitioners ways to deliver better patient care for improved patient outcomes. The objective of an integrative review is to deliver a current synthesis of knowledge regarding a clinical problem for a specific population, using evidence-based research to support practice. Advanced practice registered nurses (APRNs), such as the Certified Registered Nurse Anesthetist (CRNA) must strive to deliver safe care, using evidence-based practice, to improve the quality of life for the patient. Understanding the effects of anesthetics on the immune system and providing the safest delivery should be a standard of care, especially for susceptible cancer patients. Other than metastasis in the cancer patient, non-cancer patients are also at risk for life threatening infections from immune suppression. The importance of this review is for practitioners to understand what is being delivered to their patients, the harmful effects that could result from immune suppression and alternatives to bypass or minimize potential hazards. Identifying alternative ways to provide anesthesia/analgesia to facilitate surgical treatment to avoid, or minimize, immune suppression for cancer patients is imperative. A comprehensive synthesis of research which recommends RA use over GA use has been included.

Collaboration in the medical field is necessary to ensure best practice and outcomes. This starts with the registered nurse in the preoperative period prior to entering the operative room. The administration of opioids begins the cascade of altering the immune system defenses. Entering the operating room and starting the induction of anesthesia with the CRNA and the anesthesiologist is the next insult to the defense system. Administration of volatile gases from the anesthesia team and the response to 
surgical stress initiated by the surgeon, is the third insult. Postoperative care involving patient controlled opioid pumps ordered by APRNs and medical doctors, is a potential fourth insult to the immune system. There are many contributors impacting the overall outcome for the surgical patient.

Although the CRNA does not always decide on the full plan of care for the patient, they can propose recommendations based on the best evidence. Staying up-todate with current research is a necessity to provide satisfactory care. Educating APRNs, registered nurses, surgeons, and anesthesiologists via research dissemination, as well as best practice alert emails, would be a way to integrate significant empirical evidence with current practices. Educating surgeons on the benefits of epidural anesthesia and the ability to perform certain surgeries and provide postoperative pain control via this method could ameliorate immune defense dysfunction. Educating registered nurses on alternatives to opioid analgesia could prompt them to suggest future alternatives for their patients. Advocating for regional anesthesia workshops for both CRNAs and anesthesiologists to enhance skills would be a great way to promote an increase in frequency of regional anesthesia use.

Based on this review, the CRNA can make evidence based clinical decisions to improve outcomes and avoid future risks for susceptible patients. Assisting as a researcher, educator, advocate and mentor are responsibilities of the CRNA, and will be needed to foster clinical practice change. Understanding immune effects from everyday used medications may help educate and change future practice. As the CRNAs scope of practice evolves to meet the needs of individual patients, an understanding of this important topic is necessary and will be a common topic for discussion in the near future. 
This review will be helpful in providing supporting evidence for future research. The information provided is relevant and consistent, however, the need for large prospective trials are still warranted. 


\section{References}

Bajwa, S., Jit, S., Anandl, S., \& Kaur, G. (2015). Anesthesia and cancer recurrences: the current knowledge and evidence. Journal of Cancer Research and Therapeutics. 11(3), p. 528- 534. doi:10.4103/0973-1482.157321

Bharati, S., Chowdhury, T., Bergese, S., \& Ghosh, S. (2016). Anesthetics impact on cancer recurrence: what do we know? Journal of Cancer Research and Therapeutics. 12(2), p. 464-468. doi:10.4103/0973-1482.148670

Biki, B., Mascha, E., Moriarty, D., Fitzpatrick, J., Sessler, D., \& Buggy, D. (2008). Anesthetic technique for radical prostatectomy surgery affects cancer recurrence. Anesthesiology. 109, p. 180-187.

Brox, T., Chan, P., Cafri, G., \& Inacio, M. (2016). Similar mortality with general or regional anesthesia in elderly hip fracture patients. Acta Orthopaedica. 87(2), p. $152-157$.

Buckley, A., McQuaid, S., Johnson, P.,\& Buggy, D. (2014). Effect of anaesthetic technique on the natural killer cell anti-tumor activity of serum from women undergoing breast cancer surgery: a pilot study. British Journal of Anaesthesia. 113(1), p. i56-i62.

Cata J., Chavez-MacGregor, M., Valero, V., Black, W., Black D., Goravanchi, F.,...\& Gottumukkala, V. (2016) The impact of paravertebral block analgesia on breast cancer survival after surgery. Regional Anesthesia Pain Medicine. 41(6), p. 696703. 
Chen, W., \& Miao, C. (2013). The effect of anesthetic technique on survival in human cancers: a meta-analysis of retrospective and prospective studies. PLOS ONE. 8(2), p.1-6.

Cho, J., Lee, M., Kim, S., Park, S., Park, H., Oh, E.,... \& Koo, B. (2017). The effects of perioperative anesthesia and analgesia on immune function in patients undergoing breast cancer resection: a prospective randomized study. International Journal of Medical Sciences. 14(10), p. 970-976).

Christopherson, R., James, K., Tableman, M., Marshall, P., \& Johnson, F. (2008). Longterm survival after colon cancer surgery: a variation associated with choice of anesthesia. Regional Anesthesia. 107(1), p. 325-332.

Critical Appraisal Skills Programme. (2017). CASP systematic reviews checklist. Retrieved from http://docs.wixstatic.com/ugd/dded87_7e983a320087439e945 33f4697aa109c.pdf

Cummings, K., Xu, F., Cummings, L., \& Cooper, G. (2012). A comparison of epidural analgesia and traditional pain management effects on survival and cancer recurrence after colectomy. Anesthesiology. 116(4), p. 797-806.

Deegan, C., Murray, D., Doran, P., Ecimovic, P., Moriarty, D., \& Buggy, D. (2009). Effects of anaesthetic technique on oestrogen receptor-negative breast cancer cell function in vitro. British Journal of Anaesthesia. 103, p. 685-690.

Deegan, C., Murray, D., Doran, P., Moriarty, D., Selssler, D., Mascha, E.,...\& Buggy, D. (2010). Anesthetic technique and the cytokine and matrix metalloproteinase response to primary breast cancer surgery. Regional Anesthesia Pain Medicine. 35(6), p. 490-495. 
Desmond, F., McCormack, J., Mulligan, N., Stokes, M., \& Buggy, D. (2015). Effect of anaesthetic technique on immune cell infiltration in breast cancer: a follow-up pilot analysis of a prospective, randomized, investigator-masked study. Anticancer Research. 35, p. 1311-1319.

Dhabhar, F. (2009). Enhancing vs. suppressive effects of stress on immune function: implications for immunoprotection and immunopathology. Neuro Immunomodulation. 16, p. 300-317. doi:10.1159/000216188

Exadaktylos, A., Buggy, D., Moriarty, D., Mascha, E., \& Sessler, D. (2006). Can anesthetic technique for primary breast cancer surgery affect recurrence or metastasis? The American Society of Anesthesiologists. 105, p.660-664.

Finn, D., Ilfeld, B., Unkart, J., Madison, S., Suresh, P., Sandhu, N.,... \& Wallace, A. (2017). Post-mastectomy cancer recurrence with and without a continuous paravertebral block in the immediate postoperative period: a prospective multiyear follow-up pilot study of a randomized, triple-masked, placebo-controlled investigation. Journal of Anesthesiology. 31 (3), p. 374-379.

Flood, P., Rathmell, J., \& Shafer, S. (2015). Stoelting’s Pharmacology \& Physiology in Anesthetic Practice (5 ${ }^{\text {th }}$ ed.). Philadelphia: Wolters Kluwer Health/ Lippincott Williams \& Wilkins.

Flores, I., Sierra-Fonseca, J., Davalos, O., Saenz, L., Castellanos, M., Zavala, J., \& Gosselink, K. (2017). Stress alters the expression of cancer-related genes in the prostate. BMC Cancer. 17, p. 617-621. 
Fuentes, J., Talamini, M., Fulton, W., Hanly, E., Aurora, A., \& De Maio, A. (2006). General anesthesia delays the inflammatory response and increases survival for mice with endotoxic shock. Clinical and Vaccine Immunology. 13(2), p. 281-288.

Gottschalk, A., Sharma, S., Ford, J., Durieux, M., \& Tiouririne, M. (2010). The role of the perioperative period in recurrence after cancer surgery. Anesthesia-Analgesia. 110(6), p. 1636-1643.

Griffis, C., Page, G., Kremer, M., \& Yermal, S. (2008). Implications of immune function to anesthesia care. AANA. 76(6), p. 449-454.

Heinrich, S., Janitz, K., Merkel, S., Klein, P., \& Schmidt, K. (2015). Short and long-term effects of epidural analgesia on morbidity and mortality of esophageal cancer surgery. Langenbecks Archives of Surgery. 400, p. 19-26.

Hoekstra, H., Wobbes, T., Heineman, E., Haryono, S., Aryandono, T., \& Balch, C. (2015). Fighting global disparities in cancer care: a surgical oncology view. Annals of Surgical Oncology. 23(7), p.2131-2136. doi:10.1245/s10434-016-51943

Jang, D., Seong, L., Sup Shin, Y., Park, S., Hyun Song, S., \& Jun Kim, B. (2016). A comparison of regional and general anesthesia effects on 5-year survival and cancer recurrence after transurethral resection of the bladder tumor: a retrospective analysis. Anesthesiology. 16(16), p. 1-6.

Jaura, A., Flood, G., Gallagher, H., \& Buggy, D. (2014). Differential effects of serum f rom patients administered distant anaesthetic techniques on apoptosis in breast cancer cells in vitro: a pilot study. British Journal of Anaesthesia. 113, p. i63-i67. Kairaluoma, P., Mattson, J., Heikkila, P., Pere, P., \& Leidenius, M. (2016). Perioperative 
paravertebral regional anaethesia and breast cancer recurrence. Anticancer Research. 36, p. 415-418.

Kurosawa, S., \& Kato, M. (2008). Anesthetics, immune cells, and immune responses. Journal of Anesthesia. 22, p. 263-277. doi:10.1007/s00540-008-0626-2

Lai, M., Peng, Z., Chen, D., Wang, X., Xing, W., Zeng, W., \& Chen, M. (2012). The effect of anesthetic technique on cancer recurrence in percutaneous radiofrequency ablation of small hepatocellular carcinoma. Clinical Pharmacology. 114(2), p. 290-296.

Levy, E., Roverti, M., \& Mordoh, J. (2011). Natural killer cells in human cancer: from biological functions to clinical applications. Journal of Biomedicine and Biotechnology. 2011, p. 1-11. doi:10.11552011/676198

Le-Wendling, l., Nin, O., \& Capdevila, X. (2015). Cancer recurrence and regional anesthesia: the theories, the data, and the future in outcomes. Pain Medicine. 17, p. 756-775. Doi:10.1111/pme.12893

Lin, L., Liu, C., Tan, H., Ouyang, H., Zhang, Y., \& Zeng, W. (2011). Anaesthetic technique may affect prognosis for ovarian serous adenocarcinoma: a retrospective analysis. British Journal of Anaesthesia. 106(6), p. 814-822.

Looney, M., Doran, P., \& Buggy D. (2010). Effect of anesthetic technique on serum vascular endothelial growth factor $\mathrm{c}$ and transforming growth fact beta in women undergoing anesthesia and surgery for breast cancer. Anesthesiology. 113, p. $1118-1125$. 
Loop, T., Dovi-Akue, D., Med, C., Frick, M., Med, C., Roesslein,... \& Pannen, B. (2005). Volatile anesthetics induce caspase-dependent, mitochondria-mediated apoptosis in human T-lymphocytes in vitro. Anesthesiology. 102, p. 1147-1157.

Narahara, H., Kadoi, Y., Hinohara, H., Kunimoto, F., \& Saito, S. (2013). Comparative effects of flurbiprofen and fentanyl on natural killer cell cytotoxicity, lymphocyte subsets and cytokine concentrations in post-surgical intensive care unit patient: prospective randomized study. Japanese Society of Anesthesiologists. 27, p. 676683.

Narita, S., Tsuchiya, N., Kumasawa, T., Maita, S., Numakura, K., Obara, T.,...\& Habuchi, T. (2005). Comparison of surgical stress in patients undergoing open vs. laparoscopic radical prostatectomy by measuring perioperative serum cytokine levels. Laparoendoscopic and Advanced Surgical Techniques. 23 (1), p. 33-37.

O’Riain, S., Buggy, D., Kerin, M., Watson, R., \& Moriarty, D. (2005). Inhibition of the stress response to breast cancer surgery by regional anesthesia and analgesia does not affect vascular endothelial growth factor and prostaglandin E2. Anesthesia \& Analgesia. 100, p. 244-249.

Palumbo, J., Talmage, K., Massari, J., La Jeunesse, C., Flick, M., Kombrinck, K.,... \& Degen, J. (2005). Platelets and fibrin(ogen) increase metastatic potential by impeding natural killer cell-mediated elimination of tumor cells. Blood. 105(1), p. $178-185$.

Perez-Gonzalez, O., Cuellare-Guzman, L., Soliz, J., \& Cata, J. (2017). Impact of regional 
anesthesia on recurrence, metastasis, and immune response in breast cancer surgery: a systematic review of the literature. Regional Anesthesia and Acute Pain. 42(6), p. 751-756.

Polit, D., \& Beck, C. (2014). Essentials of Nursing Research. (4 ${ }^{\text {th }}$ ed.). Philadelphia: Wolters Kluwer Health / Lippincott Williams \& Wilkins

Ramirez, M., Ai, D., Bauer, M., Vauthey, J., Gottumukkala, V., Kee, S.,... \& Cata, J. (2015). Innate immune function after breast, lung, and colorectal cancer surgery. Journal of Surgical Research. 194(1), p. 185-193.

Saul, A., Oberyszyn, T., Daugherty, C., Kusewitt, D., Jones, S., Jewell, S.,... \& Dhabhar, F. (2012). Chronic stress and susceptibility to skin cancer. National Cancer Institute. 97 (23), p. 1760-1767.

Scavonetto, F., Yeoh, T., Umbreit, E., Weingarten, T., Gettman, M., Frank, J.,... \& Sprung, J. (2014). Association between neuraxial analgesia, cancer progression, and mortality after radical prostatectomy: a large, retrospective matched cohort study. British Journal of Anaesthesia. 113(1), p. i95-i102.

Smith, S., \& Vale, W. (2006). The role of the hypothalamic-pituitary-adrenal axis in neuroendocrine response to stress. Dialogues Clinical Neuroscience. 8(4), p. 385395.

Starnes-Ott, K., Goravanchi, F., \& Meininger, J. (2015). Anesthetic choices and breast cancer recurrence: a retrospective pilot study of patient, disease, and treatment factors. Critical Care Nursing Quality. 38, p. 200-210.

Stollings, L., Jia, L., Tang, P., Dou, H., Lu, B., \& Xu, Y. (2016). Immune modulation by volatile anesthetics. Anesthesiology. 125(2), p. 399-411. 
Sultan, S. (2013). Paravertebral block can attenuate cytokine response when it replaces general anesthesia for cancer breast surgeries. Saudi Journal of Anaesthesia. 7, p. 373-377.

Tai, L., Tanese de Souza, C., Belanger, S., Ly, L., Alkayyal, A., Zhang, J.,... \& Auer, R. (2012). Preventing postoperative metastatic disease by inhibiting surgery-induced dysfunction in Natural Killer cells. Microenvironment and Immunology. 73(1), p. $97-107$

Torre, L., Bray, F., Siegel, R., Ferlay, J., Lortet- Tieulent, J., \& Jemal, A. (2015). Global cancer statistics, 2012. A Cancer Journal for Clinicians. 65, p. 87-108.

Tosato, M., Zamboni, V., Ferrini, A., \& Cesari, M. (2007). The aging process and potential interventions to extend life expectancy. Clinical Interventions in Aging. 2(3), p. 401-412. Retrieved from https://www.ncbi.nlm.nih.gov/pmc/articles /PMC2685272/

Tsigonis, A., Al-Hamadani, M., Linebarger, J, Vang, C., Krause, F., Johnson, J.,... \& Landercasper, J. (2016). Are cure rates for breast cancer improved by local and regional anesthesia? Regional Anesthesia Pain Medicine. 41, p. 339-347.

Weiser, T., Regenbogen, S., Thompson, K., Haynes, A., Lipsitz, S., Berry, W., \& Gawande, A. (2008). An estimation of the global volume of surgery: a modeling strategy based on available data. Lancet. 372, p. 139-144. doi:10.1016/s014406736(08)60878-8.

Welden, B., Gates, G., Mallari, R., \& Garrett, N. (2009). Effect of anesthetics and analgesics on natural killer cell activity. AANA. 77(4), p. 287-292. 
Whittemore, R., \& Knafl, K. (2005). The integrative review: updated methodology. Journal of Advanced Nursing. 52(5), p. 546-553.

Woo, J., Baik, H., Kim, C., Chung, R., Kim, D., Lee, G., \& Chun, E. (2015). Effect of Propofol and Desflurane on immune cell population in breast cancer patients: a randomized trial. Journal of Korean Medical Science. 30(10), p. 1503-1508. 


\section{Appendix A-1}

Exadaktylos, Buggy, Moriarty, Mascha, and Sessler. (2006). Can anesthetic technique for primary breast cancer surgery affect recurrence or metastasis?

\begin{tabular}{|c|c|c|}
\hline $\begin{array}{l}\text { Aspect of the } \\
\text { Report }\end{array}$ & Critiquing Questions & Detailed Critiquing Guidelines \\
\hline Title & $\begin{array}{l}\text { Is the title a good one, } \\
\text { succinctly suggesting } \\
\text { key variables and the } \\
\text { study population? }\end{array}$ & $\begin{array}{l}\text { - The title is } 12 \text { words in length and } \\
\text { clearly identifies for the reader the } \\
\text { purpose of the study. It identifies } \\
\text { what is to be studied and the } \\
\text { population being assesses }\end{array}$ \\
\hline Abstract & $\begin{array}{l}\text { Did the abstract clearly } \\
\text { and concisely } \\
\text { summarize the main } \\
\text { features of the report } \\
\text { (problem, methods, } \\
\text { results, conclusions)? }\end{array}$ & $\begin{array}{l}\text { - Authors provide the reader with a } \\
\text { succinct overview of the study and } \\
\text { include information regarding the } \\
\text { purpose, the methods and sample } \\
\text { size, findings and conclusions. }\end{array}$ \\
\hline $\begin{array}{l}\text { Introduction } \\
\text { Statement of the } \\
\text { problem }\end{array}$ & $\begin{array}{l}\text { Was the problem stated } \\
\text { unambiguously, and } \\
\text { was it easy to identify? } \\
\text { Does the problem } \\
\text { statement build a } \\
\text { persuasive argument for } \\
\text { the new study? } \\
\text { Was there a good match } \\
\text { between the research } \\
\text { problem and the } \\
\text { methods used -that is, } \\
\text { was a quantitative } \\
\text { approach appropriate? }\end{array}$ & $\begin{array}{l}\text { - The problem statement was concise } \\
\text { and easy to understand and locate by } \\
\text { the reader. } \\
\text { The authors identify the effect of } \\
\text { anesthetic technique on breast } \\
\text { cancer outcome had not been } \\
\text { conducted in the clinical setting. } \\
\text { - The problem statement built a good } \\
\text { argument for this study. Authors } \\
\text { acknowledged previous studies have } \\
\text { shown perioperative factors, } \\
\text { including regional anesthesia and } \\
\text { postoperative analgesia have shown } \\
\text { reductions in the metastatic problem } \\
\text { in animals with breast } \\
\text { adenocarcinomas. } \\
\text { Authors recognize that inhibition of } \\
\text { the surgical stress response by } \\
\text { paravertebral anesthesia could } \\
\text { attenuate perioperative factors that } \\
\text { enhance tumor growth and spread. } \\
\text { Authors build their argument for the } \\
\text { study by identifying limited research } \\
\text { on the effect of anesthetic technique } \\
\text { on breast cancer outcomes in the } \\
\text { clinical setting. }\end{array}$ \\
\hline $\begin{array}{l}\text { Hypotheses or } \\
\text { research } \\
\text { questions }\end{array}$ & $\begin{array}{l}\text { Were research questions } \\
\text { and/or hypotheses } \\
\text { explicitly stated? If not, }\end{array}$ & $\begin{array}{l}\text { - The authors hypothesized that breast } \\
\text { cancer patients undergoing surgery } \\
\text { with PVB combined with general }\end{array}$ \\
\hline
\end{tabular}




\begin{tabular}{|c|c|c|}
\hline & $\begin{array}{l}\text { was their absence } \\
\text { justified? } \\
\text { Were questions and } \\
\text { hypotheses } \\
\text { appropriately worded, } \\
\text { with clear specification } \\
\text { of key variables and the } \\
\text { study population? } \\
\text { Were the } \\
\text { questions/hypotheses } \\
\text { consistent with existing } \\
\text { knowledge? }\end{array}$ & $\begin{array}{l}\text { anesthesia have a lower incidence of } \\
\text { cancer recurrence/metastases than } \\
\text { patients undergoing surgery with } \\
\text { general anesthesia and patient- } \\
\text { controlled morphine analgesia. } \\
\text { - The hypothesis was consistent with } \\
\text { existing knowledge supported by } \\
\text { background information as well as } \\
\text { the literature review. }\end{array}$ \\
\hline $\begin{array}{l}\text { Literature } \\
\text { review }\end{array}$ & $\begin{array}{l}\text { Was the literature } \\
\text { review up-to-date and } \\
\text { based mainly on } \\
\text { primary sources? } \\
\text { Did the review provide } \\
\text { a state-of-the-art } \\
\text { synthesis of evidence on } \\
\text { the problem? } \\
\text { Did the literature review } \\
\text { provide a strong basis } \\
\text { for the new study? }\end{array}$ & $\begin{array}{l}\text { - The literature review is based } \\
\text { mainly on primary sources from } \\
\text { 1998-2005. } \\
\text { The authors discuss the } \\
\text { understanding that regional } \\
\text { anesthesia attenuates the surgical } \\
\text { stress response by the blocking of } \\
\text { afferent neural transmission. Further } \\
\text { the authors explain the PVB } \\
\text { anesthesia and its use in suppression } \\
\text { of surgical stress response in breast } \\
\text { cancer surgery, without a reduction } \\
\text { in associated tumor cell } \\
\text { angiogenesis. This has been } \\
\text { explored in animals but not in } \\
\text { human clinical settings. } \\
\text { The introduction sets the stage for } \\
\text { the new study by describing the gap } \\
\text { of breast cancer outcomes not being } \\
\text { evaluated in the clinical setting. }\end{array}$ \\
\hline $\begin{array}{l}\text { Conceptual/ } \\
\text { theoretical } \\
\text { framework }\end{array}$ & $\begin{array}{l}\text { Were key concepts } \\
\text { adequately defined } \\
\text { conceptually? } \\
\text { Was a } \\
\text { conceptual/theoretical } \\
\text { framework } \\
\text { articulated-and, if so, } \\
\text { was it appropriate? If } \\
\text { not, is the absence of a } \\
\text { framework justified? } \\
\text { Were the } \\
\text { questions/hypotheses }\end{array}$ & $\begin{array}{l}\text { Key concepts were addressed and } \\
\text { with brief conceptual definitions. } \\
\text { - Concepts were defined to a specific } \\
\text { population. Authors did not further } \\
\text { explore/explain regional anesthesia } \\
\text { for the general population. } \\
\text { - No framework was articulated in } \\
\text { this study. }\end{array}$ \\
\hline
\end{tabular}




\begin{tabular}{|c|c|c|}
\hline & $\begin{array}{l}\text { consistent with the } \\
\text { framework? }\end{array}$ & \\
\hline $\begin{array}{l}\text { Method } \\
\text { Protection of } \\
\text { human rights }\end{array}$ & $\begin{array}{l}\text { Were appropriate } \\
\text { procedures used to safe- } \\
\text { guard the rights of study } \\
\text { participants? } \\
\text { Was the study } \\
\text { externally reviewed by } \\
\text { an IRB/ethics review } \\
\text { board? } \\
\text { Was the study designed } \\
\text { to minimize risks and } \\
\text { maximize benefits to } \\
\text { participants? }\end{array}$ & $\begin{array}{l}\text { Approval was obtained by the ethics } \\
\text { committee of the Mater } \\
\text { Misericordiae University Hospital, } \\
\text { Dublin, Ireland. } \\
\text { This type of study was designed to } \\
\text { minimize risks and maximize } \\
\text { benefits to future breast cancer } \\
\text { patients. }\end{array}$ \\
\hline Research design & $\begin{array}{l}\text { Was the most rigorous } \\
\text { design used, given the } \\
\text { study purpose? } \\
\text { Were appropriate } \\
\text { comparisons made to } \\
\text { enhance interpretability } \\
\text { of the findings? } \\
\text { Was the number of data } \\
\text { collection points } \\
\text { appropriate? } \\
\text { Did the design } \\
\text { minimize biases and } \\
\text { threats to the internal, } \\
\text { construct, and external } \\
\text { validity of the study } \\
\text { (e.g., was blinding used, } \\
\text { was attrition } \\
\text { minimized)? }\end{array}$ & $\begin{array}{l}\text { - A Retrospective design is not the } \\
\text { most rigorous design that could be } \\
\text { used for this study purpose. } \\
\text { Randomized control trials would be } \\
\text { the most rigorous design. This } \\
\text { retrospective study was used to } \\
\text { review past cases to evaluate the } \\
\text { effects of PVB vs. GA and the } \\
\text { effects on cancer recurrence and } \\
\text { metastasis. } \\
\text { Appropriate comparisons were made } \\
\text { to enhance the findings including } \\
\text { anesthetic technique, age, time from } \\
\text { surgery to recurrence, duration of } \\
\text { surgery, blood loss during surgery, } \\
\text { pain score, tumor grades, lymph } \\
\text { node involvement. } \\
\text { Numbers of PVB/GA vs. } \\
\text { GA/morphine were not even and } \\
\text { could have included a larger sample } \\
\text { size. } \\
\text { The same anesthetist placed all PVB } \\
\text { catheters, and the same surgeon } \\
\text { performed all of the operations, and } \\
\text { the oncologist for all the patients } \\
\text { was the same as well. } \\
\text { With operations, data entry and }\end{array}$ \\
\hline
\end{tabular}




\begin{tabular}{|c|c|c|}
\hline & & $\begin{array}{l}\text { collection already completed, this } \\
\text { compromises the study and is } \\
\text { considered selection bias as well. } \\
\text { Other biases include lack of follow- } \\
\text { up and unknown deaths. }\end{array}$ \\
\hline $\begin{array}{l}\text { Population and } \\
\text { sample }\end{array}$ & $\begin{array}{l}\text { Was the population } \\
\text { identified? Was the } \\
\text { sample described in } \\
\text { sufficient detail? } \\
\text { Was the best possible } \\
\text { sampling design used to } \\
\text { enhance the sample? } \\
\text { Were sampling biases } \\
\text { minimized? } \\
\text { Was the sample size } \\
\text { based on a power } \\
\text { analysis? }\end{array}$ & $\begin{array}{l}\text { The population was clearly } \\
\text { identified as breast cancer patients } \\
\text { who underwent mastectomy with } \\
\text { axillary clearance or simple } \\
\text { mastectomy from Sept. 2001-Dec. } \\
2002 \text {. } \\
\text { - Retrospective studies have selection } \\
\text { bias because the population was } \\
\text { based on treatment and outcomes } \\
\text { and is predetermined without } \\
\text { randomization. } \\
\text { - Sample size was not based on a } \\
\text { power analysis. }\end{array}$ \\
\hline $\begin{array}{l}\text { Data collection } \\
\text { and } \\
\text { measurement }\end{array}$ & $\begin{array}{l}\text { Were the operational } \\
\text { and conceptual } \\
\text { definitions congruent? } \\
\text { Were key variables } \\
\text { measured using an } \\
\text { appropriate method? } \\
\text { Were specific } \\
\text { instruments described } \\
\text { and were they good } \\
\text { choices, given the study } \\
\text { population and the } \\
\text { variables being studied? } \\
\text { Did the report provide } \\
\text { evidence that the data } \\
\text { collection methods } \\
\text { yielded data that were } \\
\text { reliable, valid and } \\
\text { responsive? }\end{array}$ & 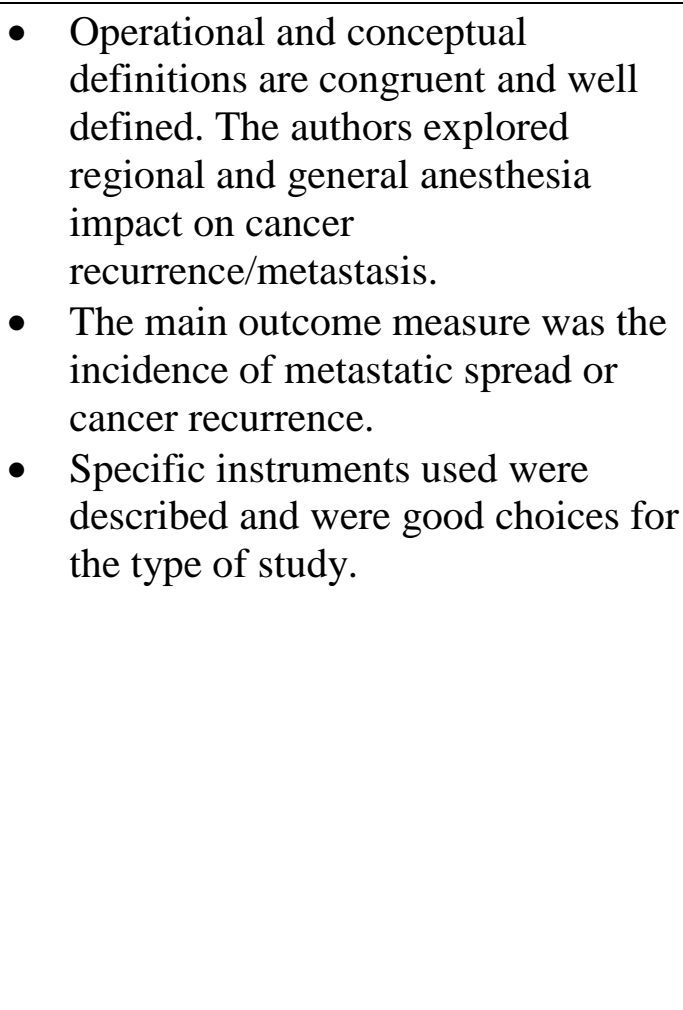 \\
\hline Procedures & $\begin{array}{l}\text { If there was an } \\
\text { intervention, was it } \\
\text { adequately described, } \\
\text { and was it rigorously } \\
\text { developed and } \\
\text { implemented? }\end{array}$ & $\begin{array}{l}\text { Retrospective, observational designs } \\
\text { are not randomized so selection bias } \\
\text { and effects of unmeasured } \\
\text { confounding variable cannot be } \\
\text { excluded. } \\
\text { - } \quad \text { Data collected is prone to selection }\end{array}$ \\
\hline
\end{tabular}




\begin{tabular}{|c|c|c|}
\hline & $\begin{array}{l}\text { Did most participants } \\
\text { allocated to the } \\
\text { intervention group } \\
\text { actually receive it? } \\
\text { Was there evidence of } \\
\text { intervention fidelity? } \\
\text { Were data collected in a } \\
\text { manner that minimized } \\
\text { bias? Were the staff } \\
\text { who collected data } \\
\text { appropriately trained? }\end{array}$ & $\begin{array}{l}\text { bias, as mentioned above. Staff } \\
\text { collecting data however are } \\
\text { appropriately trained: staff includes } \\
\text { a researcher anesthesia, senior } \\
\text { lecturer in anesthesia, professors in } \\
\text { anesthesia, a statistician of } \\
\text { quantitative health science, and a } \\
\text { director of outcomes research. }\end{array}$ \\
\hline Data Analysis & $\begin{array}{l}\text { Were analyses } \\
\text { undertaken to address } \\
\text { each research question } \\
\text { or test each hypothesis? } \\
\text { Were appropriate } \\
\text { statistical methods used, } \\
\text { given the level of } \\
\text { measurement of the } \\
\text { variables, number of } \\
\text { groups being compared, } \\
\text { and assumptions of the } \\
\text { texts? } \\
\text { Was a powerful analytic } \\
\text { method used? (e.g., did } \\
\text { the analysis help to } \\
\text { control for confounding } \\
\text { variables)? } \\
\text { In intervention studies, } \\
\text { was an intention-to-treat } \\
\text { analysis performed? }\end{array}$ & $\begin{array}{l}\text { - The main outcome measure was the } \\
\text { incidence of metastatic spread or } \\
\text { cancer recurrence after use of } \\
\text { regional or general anesthesia. } \\
\text { - All of the data was recorded in } \\
\text { coded Excel form and imported into } \\
\text { SAS statistical software for analysis. } \\
\text { - Appropriate statistical methods were } \\
\text { used. } \\
\text { t- tests were used to compared } \\
\text { normally distributed continuous } \\
\text { variables, and non-normal variables } \\
\text { were compared with Mann-Whitney } \\
\text { U tests. } \\
\text { Categorical variables were } \\
\text { compared with chi-square tests or } \\
\text { Fisher exact tests. } \\
\text { A Kaplan-Meier log-rank test was } \\
\text { used for univariable analysis. } \\
\text { Cox proportional hazards regression } \\
\text { was used for multivariable analysis } \\
\text { of the time to recurrence of cancer } \\
\text { between groups. Factors for the } \\
\text { multivariable model; age, family } \\
\text { history of cancer, tumor size, } \\
\text { histologic grade, duration of } \\
\text { surgery, and blood loss. } \\
\text { were retained in the model. } \\
\text { Associations with } p<0.05 \text { were } \\
\text { deemed statistically significant. }\end{array}$ \\
\hline
\end{tabular}




\begin{tabular}{|c|c|c|}
\hline $\begin{array}{l}\text { Data Analysis } \\
\text { (continued) }\end{array}$ & $\begin{array}{l}\text { Were problems of } \\
\text { missing values } \\
\text { evaluated and } \\
\text { adequately addressed? }\end{array}$ & $\begin{array}{l}\text { - One patient died in GA group and no } \\
\text { further values were used for this } \\
\text { patient. } \\
\text { - Unmeasured confounding variables } \\
\text { cannot be excluded given the } \\
\text { retrospective design. } \\
\text { - The amounts of opioids given, and } \\
\text { the type of chemotherapy were not } \\
\text { available in the patient records. } \\
\end{array}$ \\
\hline Findings & $\begin{array}{l}\text { Was information about } \\
\text { statistical significance } \\
\text { presented? Was } \\
\text { information about } \\
\text { effect size and } \\
\text { precision of estimates } \\
\text { (confidence intervals) } \\
\text { presented? } \\
\text { Were the findings } \\
\text { adequately } \\
\text { summarized, with good } \\
\text { use of tables and } \\
\text { figures? } \\
\text { Were findings reported } \\
\text { in a manner that } \\
\text { facilitates a meta- } \\
\text { analysis, and with } \\
\text { sufficient information } \\
\text { needed for EBP? }\end{array}$ & $\begin{array}{l}\text { Statistical significance was presented. } \\
\text { Information about effect size and } \\
\text { precision estimates were presented. } \\
\text { - The findings were adequately } \\
\text { summarized and both tables and } \\
\text { narrative forms were used to do so. } \\
\text { - Confidence intervals were provided. }\end{array}$ \\
\hline $\begin{array}{l}\text { Discussion } \\
\text { Interpretation } \\
\text { of the findings }\end{array}$ & $\begin{array}{l}\text { Were all major } \\
\text { findings interpreted } \\
\text { and discussed within } \\
\text { the context of prior } \\
\text { research and/or the } \\
\text { study's conceptual } \\
\text { framework? } \\
\text { Were casual } \\
\text { inferences, if any, } \\
\text { justified? } \\
\text { Was the issue of } \\
\text { clinical significance } \\
\text { discussed? }\end{array}$ & $\begin{array}{l}\text { - Major findings were discussed within } \\
\text { the context of prior research and the } \\
\text { study's research findings. } \\
\text { - Exadaktylos et al. (2006) conclude } \\
\text { that regional anesthesia may play an } \\
\text { important role in maintaining immune } \\
\text { function during surgical intervention. } \\
\text { - Authors found significance in their } \\
\text { hypothesis: PVB for breast cancer } \\
\text { surgery reduces the risk of } \\
\text { recurrence/metastasis fourfold during } \\
\text { a } 2.5 \text { to } 4 \text { yr. follow up. } \\
\text { - Limitations were addressed; lack of } \\
\text { randomization of patients, non- } \\
\text { standardized clinical care, selection } \\
\text { bias and effect of unmeasured }\end{array}$ \\
\hline
\end{tabular}




\begin{tabular}{|c|c|c|}
\hline & $\begin{array}{l}\text { Were interpretations } \\
\text { well-founded and } \\
\text { consistent with the } \\
\text { study's limitations? } \\
\text { Did the report address } \\
\text { the issue of the } \\
\text { generalizability of the } \\
\text { findings? }\end{array}$ & confounding variables. \\
\hline $\begin{array}{l}\text { Implications/ } \\
\text { recommendati- } \\
\text { ons }\end{array}$ & $\begin{array}{l}\text { Did the researchers } \\
\text { discuss the } \\
\text { implications of the } \\
\text { study for clinical } \\
\text { practice or further } \\
\text { research_and were } \\
\text { those implications } \\
\text { reasonable and } \\
\text { complete? }\end{array}$ & $\begin{array}{l}\text { - Exadaktylos et al. (2006) believe they } \\
\text { generated a hypothesis and that an } \\
\text { estimated effect size for future large } \\
\text { randomized controlled trails is } \\
\text { warranted. }\end{array}$ \\
\hline $\begin{array}{l}\text { General Issues } \\
\text { Presentation }\end{array}$ & $\begin{array}{l}\text { Was the report well- } \\
\text { written, organized, and } \\
\text { sufficiently detailed for } \\
\text { critical analysis? } \\
\text { In intervention studies, } \\
\text { was a CONSORT } \\
\text { flowchart provided to } \\
\text { show the flow of } \\
\text { participants in the } \\
\text { study? }\end{array}$ & $\begin{array}{l}\text { - The report was well-written and } \\
\text { organized with good flow and clear } \\
\text { statistical information. } \\
\text { - A consort flowchart was not provided } \\
\text { in the study. }\end{array}$ \\
\hline $\begin{array}{l}\text { General Issues } \\
\text { Presentation } \\
\text { (continued) }\end{array}$ & $\begin{array}{l}\text { Was the report written } \\
\text { in a manner that makes } \\
\text { the findings accessible } \\
\text { to practicing nurses? }\end{array}$ & $\begin{array}{l}\text { The report was written for the general } \\
\text { anesthesia population. Numerous } \\
\text { definitions are needed for this article } \\
\text { to be made accessible to all practicing } \\
\text { nurses. } \\
\text { - No implication for nursing practice } \\
\text { was included in the written report. }\end{array}$ \\
\hline $\begin{array}{l}\text { Researcher } \\
\text { credibility }\end{array}$ & $\begin{array}{l}\text { Do the researchers' } \\
\text { clinical, substantive, or } \\
\text { methodologic } \\
\text { qualifications and } \\
\text { experience enhance } \\
\text { confidence in the } \\
\text { findings and their } \\
\text { interpretation? }\end{array}$ & $\begin{array}{l}\text { - Researchers experience does enhance } \\
\text { the confidence in the findings and } \\
\text { interpretations; with backgrounds in } \\
\text { anesthesia, research and statistics. }\end{array}$ \\
\hline $\begin{array}{l}\text { Summary } \\
\text { assessment }\end{array}$ & $\begin{array}{l}\text { Despite any } \\
\text { limitations, do the } \\
\text { study findings appear }\end{array}$ & $\begin{array}{l}\text { - Given the limitations, the significance } \\
\text { values observed can provide strength } \\
\text { to the research. A larger study would }\end{array}$ \\
\hline
\end{tabular}




\begin{tabular}{|l|l|l|}
\hline & $\begin{array}{l}\text { to be valid-do you } \\
\text { have confidence in the } \\
\text { truth value of the } \\
\text { results? }\end{array}$ & $\begin{array}{l}\text { be needed to deem truth in the value } \\
\text { of the results. } \\
\text { The study identified a benefit of } \\
\text { regional anesthesia vs. GA and } \\
\text { contribute any }\end{array}$ \\
$\begin{array}{l}\text { opioids in preserving immune } \\
\text { function. With this knowledge, the } \\
\text { study } \\
\text { that can be used in } \\
\text { nursing practice or that } \\
\text { is useful to the nursing } \\
\text { discipline? }\end{array}$ & $\begin{array}{l}\text { knowledge will help guide practice } \\
\text { and be useful to anesthesia nursing } \\
\text { disciplines }\end{array}$ \\
\hline
\end{tabular}

Note. $\mathrm{PVB}=$ paravertebral block, $\mathrm{GA}=$ general anesthesia 


\section{Appendix A-2}

Biki, Mascha., Moriarty., Fitzpatrick, Sessler, and Buggy. (2008). Anesthetic technique for radical prostatectomy surgery affects cancer recurrence: Retrospective analysis

\begin{tabular}{|c|c|c|}
\hline Aspect of the Report & Critiquing Questions & Detailed Critiquing Guidelines \\
\hline Title & $\begin{array}{l}\text { Is the title a good one, } \\
\text { succinctly suggesting } \\
\text { key variables and the } \\
\text { study population? }\end{array}$ & $\begin{array}{l}\text { The title identifies the } \\
\text { population of interest; } \\
\text { however, it does not indicate } \\
\text { which anesthetic techniques } \\
\text { are being studied. }\end{array}$ \\
\hline Abstract & $\begin{array}{l}\text { Did the abstract clearly } \\
\text { and concisely } \\
\text { summarize the main } \\
\text { features of the report } \\
\text { (problem, methods, } \\
\text { results, conclusions)? }\end{array}$ & $\begin{array}{l}\text { The abstract is organized with } \\
\text { headings allowing for easy } \\
\text { reading and identification of } \\
\text { specific interest. }\end{array}$ \\
\hline $\begin{array}{l}\text { Introduction } \\
\text { Statement of the } \\
\text { problem }\end{array}$ & $\begin{array}{l}\text { Was the problem stated } \\
\text { unambiguously, and } \\
\text { was it easy to identify? } \\
\text { Is the problem } \\
\text { statement build a } \\
\text { persuasive argument } \\
\text { for the new study? } \\
\text { Was there a good } \\
\text { match between the } \\
\text { research problem and } \\
\text { the methods used -that } \\
\text { is, was a quantitative } \\
\text { approach appropriate? }\end{array}$ & $\begin{array}{l}\text { The abstract and the } \\
\text { introduction of this review } \\
\text { provide the reader with the } \\
\text { initial concise identification of } \\
\text { the problem upfront. } \\
\text { - The problem statement sets the } \\
\text { stage for an argument for new } \\
\text { evidence to support the } \\
\text { hypothesis. }\end{array}$ \\
\hline $\begin{array}{l}\text { Hypotheses or } \\
\text { research questions }\end{array}$ & $\begin{array}{l}\text { Were research } \\
\text { questions and/or } \\
\text { hypotheses explicitly } \\
\text { stated? If not, was } \\
\text { their absence justified? } \\
\text { Were questions and } \\
\text { hypotheses } \\
\text { appropriately worded, } \\
\text { with clear specification } \\
\text { of key variables and } \\
\text { the study population? } \\
\text { Were the } \\
\text { questions/hypotheses }\end{array}$ & $\begin{array}{l}\text { - The hypothesis was explicitly } \\
\text { stated: "Recurrence of prostate } \\
\text { cancer is less common with } \\
\text { combined general anesthesia } \\
\text { and epidural analgesia than } \\
\text { with general anesthesia alone" } \\
\text { (Biki et al., 2008). } \\
\text { - The hypothesis was } \\
\text { appropriately worded including } \\
\text { the key variables: general } \\
\text { anesthesia (GA) and epidural } \\
\text { anesthesia (EA), as was the } \\
\text { study population, prostate } \\
\text { cancer patients. However, the } \\
\text { population studied included }\end{array}$ \\
\hline
\end{tabular}




\begin{tabular}{|c|c|c|}
\hline & $\begin{array}{l}\text { consistent with existing } \\
\text { knowledge? }\end{array}$ & $\begin{array}{l}\text { only patients who underwent } \\
\text { an open radical prostatectomy. } \\
\text { Hypothesis was consistent with } \\
\text { existing knowledge and } \\
\text { supported with previous } \\
\text { studies. }\end{array}$ \\
\hline Literature review & $\begin{array}{l}\text { Was the literature } \\
\text { review up-to-date and } \\
\text { based mainly on } \\
\text { primary sources? } \\
\text { Did the review provide } \\
\text { a state-of-the-art } \\
\text { synthesis of evidence } \\
\text { on the problem? } \\
\text { Did the literature } \\
\text { review provide a strong } \\
\text { basis for the new } \\
\text { study? }\end{array}$ & $\begin{array}{l}\text { - The literature review was } \\
\text { thoroughly written and easy to } \\
\text { read. } \\
\text { - The primary objective was } \\
\text { identified: Post prostatectomy } \\
\text { increase in PSA is indicative of } \\
\text { metastatic spread or local } \\
\text { cancer recurrence. } \\
\text { The literature review provided } \\
\text { a strong background of } \\
\text { knowledge to facilitate the } \\
\text { need for a new study. }\end{array}$ \\
\hline $\begin{array}{l}\text { Conceptual/theoretical } \\
\text { framework }\end{array}$ & $\begin{array}{l}\text { Were key concepts } \\
\text { adequately defined } \\
\text { conceptually? } \\
\text { Was a } \\
\text { conceptual/theoretical } \\
\text { framework } \\
\text { articulated-and, if so, } \\
\text { was it appropriate? If } \\
\text { not, is the absence of a } \\
\text { framework justified? } \\
\text { Were the } \\
\text { questions/hypotheses } \\
\text { consistent with the } \\
\text { framework? }\end{array}$ &  \\
\hline $\begin{array}{l}\text { Method } \\
\text { Protection of human } \\
\text { rights }\end{array}$ & $\begin{array}{l}\text { Were appropriate } \\
\text { procedures used to } \\
\text { safe-guard the rights of } \\
\text { study participants? } \\
\text { Was the study } \\
\text { externally reviewed by } \\
\text { an IRB/ethics review } \\
\text { board? }\end{array}$ & $\begin{array}{l}\text { Approval from the ethics } \\
\text { committee of the Mater } \\
\text { Misericordiae University } \\
\text { Hospital was obtained prior to } \\
\text { medical record review. } \\
\text { - Only records of patients with } \\
\text { invasive prostatic carcinoma } \\
\text { who underwent an open radical } \\
\text { prostatectomy were included. } \\
\text { - Clear identification of what }\end{array}$ \\
\hline
\end{tabular}




\begin{tabular}{|c|c|c|}
\hline & $\begin{array}{l}\text { Was the study designed } \\
\text { to minimize risks and } \\
\text { maximize benefits to } \\
\text { participants? }\end{array}$ & $\begin{array}{l}\text { was reviewed in each chart was } \\
\text { documented. }\end{array}$ \\
\hline Research design & $\begin{array}{l}\text { Was the most rigorous } \\
\text { design used, given the } \\
\text { study purpose? } \\
\text { Were appropriate } \\
\text { comparisons made to } \\
\text { enhance interpretability } \\
\text { of the findings? } \\
\text { Was the number of } \\
\text { data collection points } \\
\text { appropriate? } \\
\text { Did the design } \\
\text { minimize biases and } \\
\text { threats to the internal, } \\
\text { construct, and external } \\
\text { validity of the study } \\
\text { (e.g., was blinding } \\
\text { used, was attrition } \\
\text { minimized)? }\end{array}$ & $\begin{array}{l}\text { - The retrospective study was } \\
\text { appropriate for the goals of the } \\
\text { study. } \\
\text { The primary outcome measure } \\
\text { was identified and presented to } \\
\text { the readers: the incidence of } \\
\text { biochemical recurrence of } \\
\text { prostate specific antigen. } \\
\text { Appropriate comparisons were } \\
\text { made to enhance the findings. } \\
\text { The interval validity of the } \\
\text { study was compromised using } \\
\text { opioids in both the general vs. } \\
\text { the general and epidural } \\
\text { groups. The knowledge that } \\
\text { opioids independently impact } \\
\text { immunosuppression may have } \\
\text { impacted the outcome of the } \\
\text { study results. }\end{array}$ \\
\hline $\begin{array}{l}\text { Population and } \\
\text { sample }\end{array}$ & $\begin{array}{l}\text { Was the population } \\
\text { identified? Was the } \\
\text { sample described in } \\
\text { sufficient detail? } \\
\text { Was the best possible } \\
\text { sampling design used } \\
\text { to enhance the } \\
\text { sample's } \\
\text { representativeness? } \\
\text { Were sampling biases } \\
\text { minimized? } \\
\text { Was the sample size } \\
\text { based on a power } \\
\text { analysis? }\end{array}$ & $\begin{array}{l}\text { - The population was clearly } \\
\text { identified- prostate cancer } \\
\text { patients who underwent an } \\
\text { open radical prostatectomy. } \\
\text { Clear inclusion and exclusion } \\
\text { criteria were provided. } \\
\text { - The design chosen was } \\
\text { appropriate for the study. } \\
\text { - Sampling was not random, the } \\
\text { retrospective designed } \\
\text { reviewed patients who } \\
\text { underwent open radical } \\
\text { prostatectomy. } \\
\text { The sample was not based on a } \\
\text { power analysis. }\end{array}$ \\
\hline $\begin{array}{l}\text { Data collection and } \\
\text { measurement }\end{array}$ & $\begin{array}{l}\text { Were the operational } \\
\text { and conceptual } \\
\text { definitions congruent? } \\
\text { Were key variables }\end{array}$ & $\begin{array}{l}\text { Operational and conceptual } \\
\text { definitions for the study were } \\
\text { congruent. } \\
\text { - Key variables were measured } \\
\text { appropriately. }\end{array}$ \\
\hline
\end{tabular}




\begin{tabular}{|c|c|c|}
\hline & $\begin{array}{l}\text { measured using an } \\
\text { appropriate method } \\
\text { (e.g., interviews, } \\
\text { observations, and so } \\
\text { on)? } \\
\text { Were specific } \\
\text { instruments adequately } \\
\text { described and were } \\
\text { they good choices, } \\
\text { given the study } \\
\text { population and the } \\
\text { variables being } \\
\text { studied? } \\
\text { Did the report provide } \\
\text { evidence that the data } \\
\text { collection methods } \\
\text { yielded data that were } \\
\text { reliable, valid and } \\
\text { responsive? }\end{array}$ & $\begin{array}{l}\text { - Adequate descriptions of } \\
\text { anesthetic techniques used for } \\
\text { each group was described in } \\
\text { detail with each variable } \\
\text { reviewed. } \\
\text { - The report provided evidence } \\
\text { that the data collected was } \\
\text { reliable and valid. } \\
\text { - Specific instruments were used } \\
\text { to describe the variables } \\
\text { studied. }\end{array}$ \\
\hline Procedures & $\begin{array}{l}\text { If there was an } \\
\text { intervention, was it } \\
\text { adequately described, } \\
\text { and was it rigorously } \\
\text { developed and } \\
\text { implemented? Did } \\
\text { most participants } \\
\text { allocated to the } \\
\text { intervention group } \\
\text { actually receive it? } \\
\text { Was there evidence of } \\
\text { intervention fidelity? } \\
\text { Were data collected in } \\
\text { a manner that } \\
\text { minimized bias? Were } \\
\text { the staff who collected } \\
\text { data appropriately } \\
\text { trained? }\end{array}$ & 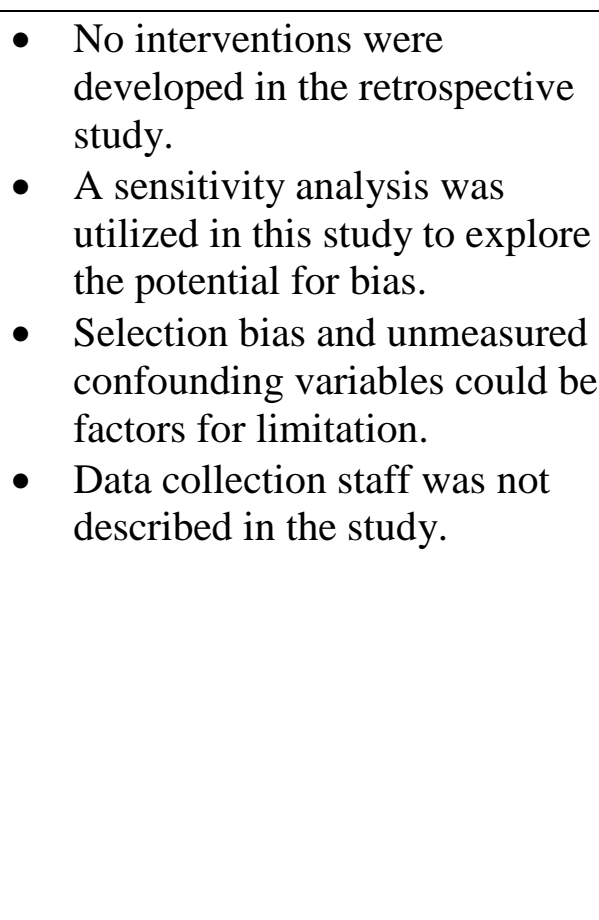 \\
\hline Data Analysis & $\begin{array}{l}\text { Were analyses } \\
\text { undertaken to address } \\
\text { each research question } \\
\text { or test each } \\
\text { hypothesis? }\end{array}$ & $\begin{array}{l}\text { Comparison of anesthetic } \\
\text { technique groups on } \\
\text { recurrence-free survival was } \\
\text { completed. The multivariable } \\
\text { cox proportional hazards } \\
\text { regression was used. }\end{array}$ \\
\hline
\end{tabular}




\begin{tabular}{|c|c|c|}
\hline & $\begin{array}{l}\text { Were appropriate } \\
\text { statistical methods } \\
\text { used, given the level of } \\
\text { measurement of the } \\
\text { variables, number of } \\
\text { groups being } \\
\text { compared, and } \\
\text { assumptions of the } \\
\text { texts? } \\
\text { Was a powerful } \\
\text { analytic method used? } \\
\text { (e.g., did the analysis } \\
\text { help to control for } \\
\text { confounding } \\
\text { variables)? } \\
\text { Were type I and Type } \\
\text { II errors avoided or } \\
\text { minimized? } \\
\text { In intervention studies, } \\
\text { was an intention-to- } \\
\text { treat analysis } \\
\text { performed? }\end{array}$ &  \\
\hline $\begin{array}{l}\text { Data Analysis } \\
\text { (continued) }\end{array}$ & $\begin{array}{l}\text { Were problems of } \\
\text { missing values } \\
\text { evaluated and } \\
\text { adequately addressed? }\end{array}$ & - $\quad \mathrm{N} / \mathrm{A}$ \\
\hline Findings & $\begin{array}{l}\text { Was information about } \\
\text { statistical significance } \\
\text { presented? Was } \\
\text { information about } \\
\text { effect size and } \\
\text { precision of estimates } \\
\text { (confidence intervals) } \\
\text { presented? } \\
\text { Were the findings } \\
\text { adequately } \\
\text { summarized, with good } \\
\text { use of tables and } \\
\text { figures? } \\
\text { Were findings reported } \\
\text { in a manner that }\end{array}$ & 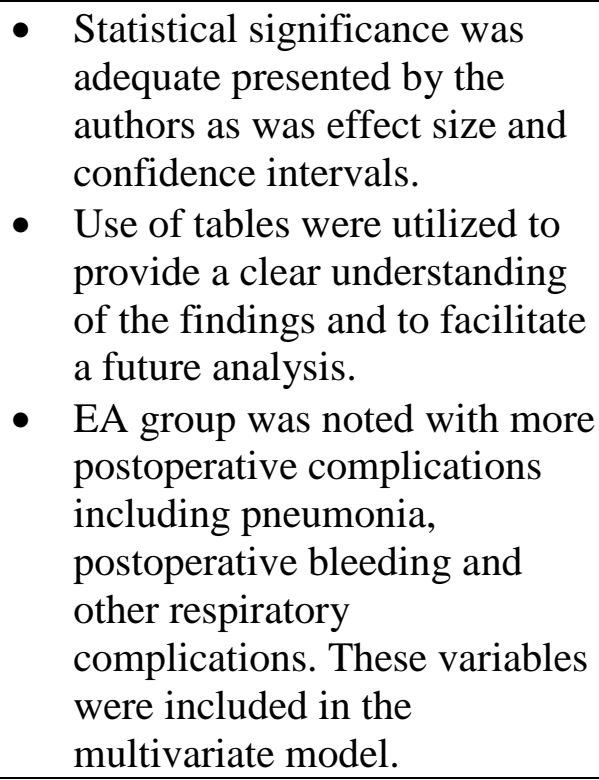 \\
\hline
\end{tabular}




\begin{tabular}{|c|c|c|}
\hline & $\begin{array}{l}\text { facilitates a meta- } \\
\text { analysis, and with } \\
\text { sufficient information } \\
\text { needed for EBP? }\end{array}$ & $\begin{array}{l}\text { Patients who received EA had } \\
\text { a lowed estimated risk of } \\
\text { recurrence to that of GA group. } \\
\text { - Research data is for a } \\
\text { retrospective review and could } \\
\text { be used for meta-analysis. }\end{array}$ \\
\hline $\begin{array}{l}\text { Discussion } \\
\text { Interpretation } \\
\text { of the findings }\end{array}$ & $\begin{array}{l}\text { Were all major } \\
\text { findings } \\
\text { interpreted/discussed } \\
\text { within the context of } \\
\text { prior research and/or } \\
\text { the study's conceptual } \\
\text { framework? } \\
\text { Were casual } \\
\text { inferences, if any, } \\
\text { justified? } \\
\text { Was the issue of } \\
\text { clinical significance } \\
\text { discussed? } \\
\text { Were interpretations } \\
\text { well-founded and } \\
\text { consistent with the } \\
\text { study's limitations? } \\
\text { Did the report address } \\
\text { the issue of the } \\
\text { generalizability of the } \\
\text { findings? }\end{array}$ & $\begin{array}{l}\text { - } \quad \text { Major findings were } \\
\text { interpreted and discussed. } \\
\text { Biki et al. (2008) identified a } \\
\text { 57\% lower risk in the EA } \\
\text { group for cancer recurrence } \\
\text { compared to GA group. } \\
\text { Propensity matching showed } \\
\text { similar results of 52\% lower } \\
\text { risk in the EA group for cancer } \\
\text { recurrence compared to the GA } \\
\text { group. } \\
\text { Limitations included: non- } \\
\text { randomized, non-standardized } \\
\text { clinical care, imprecise data } \\
\text { due to wide CI, retrospective, } \\
\text { observational design. Selection } \\
\text { bias and unmeasured } \\
\text { confounding variables cannot } \\
\text { be dismissed. } \\
\text { Biki et al. (2008) acknowledge } \\
\text { similar results in a previous } \\
\text { report in women who } \\
\text { underwent breast cancer } \\
\text { surgical intervention. } \\
\text { The need for a larger } \\
\text { randomized control trial is } \\
\text { warranted. }\end{array}$ \\
\hline $\begin{array}{l}\text { Implications/ } \\
\text { recommendati- } \\
\text { ons }\end{array}$ & $\begin{array}{l}\text { Did the researchers } \\
\text { discuss the } \\
\text { implications of the } \\
\text { study for clinical } \\
\text { practice or further } \\
\text { research-and were } \\
\text { those implications } \\
\text { reasonable and } \\
\text { complete? }\end{array}$ & $\begin{array}{l}\text { - Biki et al. (2008) discussed the } \\
\text { implications of the study and } \\
\text { the need for a larger } \\
\text { randomized control trial. }\end{array}$ \\
\hline $\begin{array}{l}\text { General Issues } \\
\text { Presentation }\end{array}$ & $\begin{array}{l}\text { Was the report well- } \\
\text { written, organized, and }\end{array}$ & $\begin{array}{l}\text { The retrospective analysis was } \\
\text { well written and organized. }\end{array}$ \\
\hline
\end{tabular}




\begin{tabular}{|c|c|c|}
\hline & $\begin{array}{l}\text { sufficiently detailed for } \\
\text { critical analysis? } \\
\text { In intervention studies, } \\
\text { was a CONSORT } \\
\text { flowchart provided to } \\
\text { show the flow of } \\
\text { participants in the } \\
\text { study? }\end{array}$ & $\begin{array}{l}\text { Easy to read for any medical } \\
\text { professional. Consort flow } \\
\text { charts were not included. }\end{array}$ \\
\hline $\begin{array}{l}\text { General Issues } \\
\text { Presentation } \\
\text { (continued) }\end{array}$ & $\begin{array}{l}\text { Was the report written } \\
\text { in a manner that makes } \\
\text { the findings accessible } \\
\text { to practicing nurses? }\end{array}$ & $\begin{array}{l}\text { The report was written to be } \\
\text { understood by medical } \\
\text { professional but finding } \\
\text { accessible to anesthesia } \\
\text { providers and surgeons. }\end{array}$ \\
\hline Researcher credibility & $\begin{array}{l}\text { Do the researchers' } \\
\text { clinical, substantive, or } \\
\text { methodologic } \\
\text { qualifications and } \\
\text { experience enhance } \\
\text { confidence in the } \\
\text { findings and their } \\
\text { interpretation? }\end{array}$ & $\begin{array}{l}\text { This article came from the } \\
\text { Anesthesiology Journal, and } \\
\text { the qualifications enhance } \\
\text { confidence in the findings and } \\
\text { interpretations. }\end{array}$ \\
\hline Summary assessment & $\begin{array}{l}\text { Despite any } \\
\text { limitations, do the } \\
\text { study findings appear } \\
\text { to be valid-do you } \\
\text { have confidence in the } \\
\text { truth value of the } \\
\text { results? } \\
\text { Does the study } \\
\text { contribute any } \\
\text { meaningful evidence } \\
\text { that can be used in } \\
\text { nursing practice or that } \\
\text { is useful to the nursing } \\
\text { discipline? }\end{array}$ & $\begin{array}{l}\text { - The study does contribute } \\
\text { meaningful evidence, however, } \\
\text { the need for a larger sample } \\
\text { size with similar ages and } \\
\text { randomization are still } \\
\text { recommended. }\end{array}$ \\
\hline
\end{tabular}

Note. $\mathrm{RA}=$ regional anesthesia, EA= epidural anesthesia, GA= general anesthesia 


\section{Appendix A-3}

Lin, Liu, Tan, Ouyang, Zhang, and Zeng. (2011). Anesthetic technique may affect prognosis for ovarian serous adenocarcinoma: a retrospective analysis.

\begin{tabular}{|c|c|c|}
\hline $\begin{array}{l}\text { Aspect of the } \\
\text { Report }\end{array}$ & Critiquing Questions & Detailed Critiquing Guidelines \\
\hline Title & $\begin{array}{l}\text { Is the title a good one, } \\
\text { succinctly suggesting } \\
\text { key variables and the } \\
\text { study population? }\end{array}$ & $\begin{array}{l}\text { The title for this article describes the } \\
\text { key points for this retrospective } \\
\text { analysis. Central topics include } \\
\text { anesthesia technique and ovarian } \\
\text { serous adenocarcinoma. The study } \\
\text { population was identified. The title } \\
\text { however did not communicate the } \\
\text { nature of the analysis of what } \\
\text { specific technique was being } \\
\text { compared. }\end{array}$ \\
\hline Abstract & $\begin{array}{l}\text { Did the abstract clearly } \\
\text { and concisely } \\
\text { summarize the main } \\
\text { features of the report } \\
\text { (problem, methods, } \\
\text { results, conclusions)? }\end{array}$ & $\begin{array}{l}\text { - The abstract was written as a } \\
\text { traditional abstract with } \\
\text { subheadings. The abstract was } \\
\text { detailed with major aspects of the } \\
\text { study described. }\end{array}$ \\
\hline $\begin{array}{l}\text { Introduction } \\
\text { Statement of } \\
\text { the problem }\end{array}$ & $\begin{array}{l}\text { Was the problem stated } \\
\text { unambiguously, and was } \\
\text { it easy to identify? } \\
\text { Does the problem } \\
\text { statement build a } \\
\text { persuasive argument for } \\
\text { the new study? } \\
\text { Was there a good match } \\
\text { between the research } \\
\text { problem and the } \\
\text { methods used -that is, } \\
\text { was a quantitative } \\
\text { approach appropriate? }\end{array}$ & $\begin{array}{l}\text { - The problem was stated and easily } \\
\text { identifiable. Ovarian serous tumors } \\
\text { were described as the most common } \\
\text { ovarian epithelial tumor, with } 1 / 3 \\
\text { being malignant adenocarcinomas. } \\
\text { - An introduction to regional } \\
\text { anesthesia and its impact on the } \\
\text { surgical stress response in } \\
\text { preserving immune function and } \\
\text { better long-term outcomes was } \\
\text { presented. }\end{array}$ \\
\hline $\begin{array}{l}\text { Hypotheses or } \\
\text { research } \\
\text { questions }\end{array}$ & $\begin{array}{l}\text { Were research questions } \\
\text { and/or hypotheses } \\
\text { explicitly stated? If not, } \\
\text { was their absence } \\
\text { justified? } \\
\text { Were questions and } \\
\text { hypotheses } \\
\text { appropriately worded, }\end{array}$ & $\begin{array}{l}\text { A research hypothesis was stated } \\
\text { patients with ovarian serous } \\
\text { adenocarcinoma who had surgery } \\
\text { with epidural anesthesia (EA) and } \\
\text { analgesia would have better long- } \\
\text { term outcome than those who were } \\
\text { given general anesthesia (GA) and } \\
\text { IV opioid analgesia. } \\
\text { - Hypothesis was worded correctly }\end{array}$ \\
\hline
\end{tabular}




\begin{tabular}{|c|c|c|}
\hline & $\begin{array}{l}\text { with clear specification } \\
\text { of key variables and the } \\
\text { study population? } \\
\text { Were the } \\
\text { questions/hypotheses } \\
\text { consistent with existing } \\
\text { knowledge? }\end{array}$ & $\begin{array}{l}\text { including the study population. } \\
\text { The hypothesis was consistent with } \\
\text { existing knowledge of other cancer } \\
\text { types; however, the study was } \\
\text { performed to prove consistency with } \\
\text { ovarian adenocarcinoma. }\end{array}$ \\
\hline $\begin{array}{l}\text { Literature } \\
\text { review }\end{array}$ & $\begin{array}{l}\text { Was the literature } \\
\text { review up-to-date and } \\
\text { based mainly on } \\
\text { primary sources? } \\
\text { Did the review provide } \\
\text { a state-of-the-art } \\
\text { synthesis of evidence on } \\
\text { the problem? } \\
\text { Did the literature review } \\
\text { provide a strong basis } \\
\text { for the new study? }\end{array}$ & $\begin{array}{l}\text { - The literature review ranged from } \\
\text { 1997-2010 from primary sources. } \\
\text { The review provided a synthesis of } \\
\text { the problem, identifying general } \\
\text { anesthetic effect on immune } \\
\text { responses by depression of bone } \\
\text { marrow activity, altering } \\
\text { phagocytosis by macrophages and } \\
\text { inducing immunosuppression. } \\
\text { A strong basis for a new study was } \\
\text { provided including evidence that } \\
\text { several clinical studies have } \\
\text { observed that different anesthetic } \\
\text { techniques have effects on tumor } \\
\text { recurrence, not including ovarian } \\
\text { serous adenocarcinoma. The } \\
\text { outcome had not been evaluated in a } \\
\text { clinical setting for the ovarian serous } \\
\text { adenocarcinoma. }\end{array}$ \\
\hline $\begin{array}{l}\text { Conceptual/ } \\
\text { theoretical } \\
\text { framework }\end{array}$ & $\begin{array}{l}\text { Were key concepts } \\
\text { adequately defined } \\
\text { conceptually? } \\
\text { Was a } \\
\text { conceptual/theoretical } \\
\text { framework articulated- } \\
\text { and, if so, was it } \\
\text { appropriate? If not, is } \\
\text { the absence of a } \\
\text { framework justified? } \\
\text { Were the } \\
\text { questions/hypotheses } \\
\text { consistent with the } \\
\text { framework? }\end{array}$ & $\begin{array}{l}\text { - } \text { Key concepts were adequately } \\
\text { addressed. Authors clearly described } \\
\text { the actions for the analysis: A } \\
\text { retrospective analysis of medical } \\
\text { records was reviewed to compare } \\
\text { survival time in patients who had } \\
\text { ovarian serous adenocarcinoma } \\
\text { surgery with either EA and analgesia } \\
\text { or GA combined with postoperative } \\
\text { intravenous analgesia. } \\
\text { - No framework was articulated. }\end{array}$ \\
\hline $\begin{array}{l}\text { Method } \\
\text { Protection of } \\
\text { human rights }\end{array}$ & $\begin{array}{l}\text { Were appropriate } \\
\text { procedures used to safe- } \\
\text { guard the rights of study }\end{array}$ & $\begin{array}{l}\text { - The ethics committee of the Sun } \\
\text { Yat-sen University Cancer Center } \\
\text { approved the research study. The }\end{array}$ \\
\hline
\end{tabular}




\begin{tabular}{|c|c|c|}
\hline & $\begin{array}{l}\text { participants? } \\
\text { Was the study externally } \\
\text { reviewed by an } \\
\text { IRB/ethics review } \\
\text { board? } \\
\text { Was the study designed } \\
\text { to minimize risks and } \\
\text { maximize benefits to } \\
\text { participants? }\end{array}$ & $\begin{array}{l}\text { medical records of all patients who } \\
\text { underwent ovarian serous } \\
\text { adenocarcinoma surgery at the } \\
\text { center between January } 1994 \text { and } \\
\text { October } 2006 \text { were reviewed. } \\
\text { The retrospective design minimizes } \\
\text { physical risk to patients and } \\
\text { maximizes benefits for future cases } \\
\text { and research. }\end{array}$ \\
\hline $\begin{array}{l}\text { Research } \\
\text { design }\end{array}$ & $\begin{array}{l}\text { Was the most rigorous } \\
\text { design used, given the } \\
\text { study purpose? } \\
\text { Were appropriate } \\
\text { comparisons made to } \\
\text { enhance interpretability } \\
\text { of the findings? } \\
\text { Was the number of data } \\
\text { collection points } \\
\text { appropriate? } \\
\text { Did the design minimize } \\
\text { biases and threats to the } \\
\text { internal, construct, and } \\
\text { external validity of the } \\
\text { study (e.g., was blinding } \\
\text { used, was attrition } \\
\text { minimized)? }\end{array}$ & $\begin{array}{l}\text { - This retrospective analysis was not } \\
\text { the most rigorous but was the most } \\
\text { appropriate design given the study } \\
\text { purpose. } \\
\text { - The comparison of EA and GA with } \\
\text { analgesia was reviewed. } \\
\text { - The number of data collection points } \\
\text { was appropriate for the analysis. } \\
\text { - Survival analysis was made with the } \\
\text { main outcome measure of death. }\end{array}$ \\
\hline $\begin{array}{l}\text { Population and } \\
\text { sample }\end{array}$ & $\begin{array}{l}\text { Was the population } \\
\text { identified? Was the } \\
\text { sample described in } \\
\text { sufficient detail? } \\
\text { Was the best possible } \\
\text { sampling design used to } \\
\text { enhance the sample's } \\
\text { representativeness? } \\
\text { Were sampling biases } \\
\text { minimized? } \\
\text { Was the sample size } \\
\text { based on a power } \\
\text { analysis? }\end{array}$ & $\begin{array}{l}\text { - A retrospective review of medical } \\
\text { records identified } 143 \text { patients with } \\
\text { ovarian serous adenocarcinoma who } \\
\text { underwent surgery; } n=106 \text { patients } \\
\text { and the GA group consisted of } n=37 \\
\text { patients. } \\
\text { - The sample was described in limited } \\
\text { detail. } \\
\text { - No information was provided about } \\
\text { patients regarding comorbidities or } \\
\text { social environments. } \\
\text { Sample size was not based on a } \\
\text { power analysis. }\end{array}$ \\
\hline
\end{tabular}




\begin{tabular}{|c|c|c|}
\hline $\begin{array}{l}\text { Data collection } \\
\text { and } \\
\text { measurement }\end{array}$ & $\begin{array}{l}\text { Were the operational } \\
\text { and conceptual } \\
\text { definitions congruent? } \\
\text { Were key variables } \\
\text { measured using an } \\
\text { appropriate method } \\
\text { (e.g., interviews, } \\
\text { observations, and so } \\
\text { on)? } \\
\text { Were specific } \\
\text { instruments adequately } \\
\text { described and were they } \\
\text { good choices, given the } \\
\text { study population and } \\
\text { the variables being } \\
\text { studied? } \\
\text { Did the report provide } \\
\text { evidence that the data } \\
\text { collection methods } \\
\text { yielded data that were } \\
\text { reliable, valid and } \\
\text { responsive? }\end{array}$ & 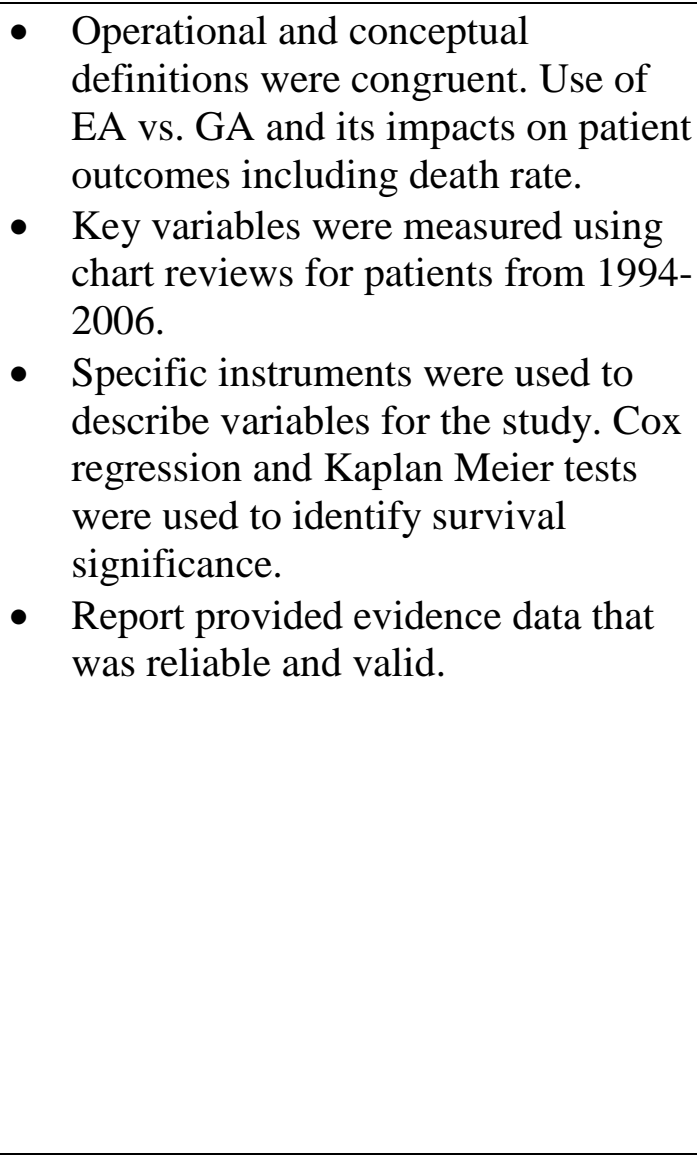 \\
\hline Procedures & $\begin{array}{l}\text { If there was an } \\
\text { intervention, was it } \\
\text { adequately described, } \\
\text { and was it rigorously } \\
\text { developed and } \\
\text { implemented? Did } \\
\text { most participants } \\
\text { allocated to the } \\
\text { intervention group } \\
\text { actually receive it? } \\
\text { Was there evidence of } \\
\text { intervention fidelity? } \\
\text { Were data collected in a } \\
\text { manner that minimized } \\
\text { bias? Were the staff } \\
\text { who collected data } \\
\text { appropriately trained? }\end{array}$ & $\begin{array}{l}\text { Interventions were not developed for } \\
\text { this study. } \\
\text { - Participants were not random, } \\
\text { allowing for selection bias. }\end{array}$ \\
\hline Data Analysis & $\begin{array}{l}\text { Were analyses } \\
\text { undertaken to address } \\
\text { each research question }\end{array}$ & $\begin{array}{l}\text { - SPSS software was used for all } \\
\text { analyses for the hypothesis. } \\
\text { - A stepwise regression with }\end{array}$ \\
\hline
\end{tabular}




\begin{tabular}{|c|c|c|}
\hline & $\begin{array}{l}\text { or test each hypothesis? } \\
\text { Were appropriate } \\
\text { statistical methods } \\
\text { used, given the level of } \\
\text { measurement of the } \\
\text { variables, number of } \\
\text { groups being compared, } \\
\text { and assumptions of the } \\
\text { texts? } \\
\text { Was a powerful } \\
\text { analytic method used? } \\
\text { (e.g., did the analysis } \\
\text { help to control for } \\
\text { confounding variables)? }\end{array}$ & $\begin{array}{l}\text { significance of }(p<0.30) \\
\text { Appropriate statistical methods were } \\
\text { utilized including; t-test or } \\
\text { Wilcoxon's rank-sum test for } \\
\text { continuous variables to compare base } \\
\text { confounding variables. } \\
\text { - Kaplan-Meier survival estimates } \\
\text { were used for univariate association } \\
\text { between overall survival and } \\
\text { anesthetic technique. } \\
\text { - Groups were compared using the } \\
\text { log-rank test. } \\
\text { Cox proportional hazards regression } \\
\text { was used for univariate association } \\
\text { between overall survival and all } \\
\text { potential baseline confounders. } \\
\text { Primary analysis compared survival } \\
\text { rate by multivariable Cox's } \\
\text { proportional hazards regression. } \\
\text { Propensity score matching was used } \\
\text { to assess the strength of the primary } \\
\text { analysis results between the type of } \\
\text { anesthesia-analgesia and survival } \\
\text { rate. }\end{array}$ \\
\hline $\begin{array}{l}\text { Data Analysis } \\
\text { (continued) }\end{array}$ & $\begin{array}{l}\text { Were problems of } \\
\text { missing values } \\
\text { evaluated and } \\
\text { adequately addressed? }\end{array}$ & $\begin{array}{l}\text { - Missing values were not addressed in } \\
\text { detail in this study. }\end{array}$ \\
\hline Findings & $\begin{array}{l}\text { Was information about } \\
\text { statistical significance } \\
\text { presented? Was } \\
\text { information about effect } \\
\text { size and precision of } \\
\text { estimates (confidence } \\
\text { intervals) presented? } \\
\text { Were the findings } \\
\text { adequately summarized, } \\
\text { with good use of tables } \\
\text { and figures? } \\
\text { Were findings reported } \\
\text { in a manner that } \\
\text { facilitates a meta- } \\
\text { analysis, and with }\end{array}$ & $\begin{array}{l}\text { - Statistical significance was presented } \\
\text { with information on effect size and } \\
\text { confidence intervals. } \\
\text { - Findings were summarized in both } \\
\text { table and narrative format. } \\
\text { - Results suggest patients who } \\
\text { underwent surgical intervention for } \\
\text { ovarian serous adenocarcinoma } \\
\text { intervention with EA had better } \\
\text { survival outcomes than GA patients. } \\
\text { - Findings were reported in a manner } \\
\text { that could facilitate a meta-analysis, } \\
\text { This research identifies testable } \\
\text { possibilities. }\end{array}$ \\
\hline
\end{tabular}




\begin{tabular}{|c|c|c|}
\hline & $\begin{array}{l}\text { sufficient information } \\
\text { needed for EBP? }\end{array}$ & \\
\hline $\begin{array}{l}\text { Discussion } \\
\text { Interpretation } \\
\text { of the findings }\end{array}$ & $\begin{array}{l}\text { Were all major findings } \\
\text { interpreted and } \\
\text { discussed within the } \\
\text { context of prior } \\
\text { research and/or the } \\
\text { study's conceptual } \\
\text { framework? } \\
\text { Were casual inferences, } \\
\text { if any, justified? } \\
\text { Was the issue of } \\
\text { clinical significance } \\
\text { discussed? } \\
\text { Were interpretations } \\
\text { well-founded and } \\
\text { consistent with the } \\
\text { study's limitations? } \\
\text { Did the report address } \\
\text { the issue of the } \\
\text { generalizability of the } \\
\text { findings? }\end{array}$ & $\begin{array}{l}\text { - Authors interpreted and discussed } \\
\text { results in the context of prior } \\
\text { research for support. } \\
\text { Results suggest potential suppression } \\
\text { of immune defense mechanisms } \\
\text { during surgery and in the } \\
\text { postoperative period. Immune } \\
\text { compromise could affect the } \\
\text { postoperative infection rate, healing, } \\
\text { and rate and extent of tumor } \\
\text { dissemination. } \\
\text { Authors recognize at least two } \\
\text { factors may account for the results of } \\
\text { the study. } \\
\text { 1. The immunosuppressive effects of } \\
\text { GA were not present in the EA } \\
\text { group. } \\
\text { 2. The dose of opioids used in the } \\
\text { of generalizability but does address } \\
\text { the need for a large prospective } \\
\text { randomized control trial. } \\
\text { EA was 10x lower than the GA } \\
\text { group. } \\
\text { Authors speculate that these two } \\
\text { factors could lead to a reduced } \\
\text { suppression of the NK cell activity, } \\
\text { and thus prevent tumor spreading. } \\
\text { in this retrospective study. } \\
\text { 1. Patients were not random, clinical } \\
\text { care was not standardized, and } \\
\text { effects of unmeasured confounding } \\
\text { variables cannot be excluded. } \\
\text { 2. A large difference between sample } \\
\text { sizes existed between the two } \\
\text { groups- EA consisted of } 106 \text { patients } \\
\text { and GA consisted of } 37 \text { patients. } \\
\text { This study, like most retrospective } \\
\text { analyses, identifies testable } \\
\text { posibily. }\end{array}$ \\
\hline $\begin{array}{l}\text { Implications/ } \\
\text { recommendati- }\end{array}$ & $\begin{array}{l}\text { Did the researchers } \\
\text { discuss the implications }\end{array}$ & $\begin{array}{l}\text { Researchers discussed their findings } \\
\text { suggesting for additional questions }\end{array}$ \\
\hline
\end{tabular}




\begin{tabular}{|c|c|c|}
\hline ons & $\begin{array}{l}\text { of the study for clinical } \\
\text { practice or further } \\
\text { research-and were } \\
\text { those implications } \\
\text { reasonable and } \\
\text { complete? }\end{array}$ & $\begin{array}{l}\text { and evidence best addressed by a } \\
\text { prospective randomized-controlled } \\
\text { trial comparing the effect of epidural } \\
\text { anesthesia on ovarian cancer } \\
\text { outcome. } \\
\text { - The study also suggests future } \\
\text { studies to evaluate the effect of } \\
\text { different anesthetic techniques on the } \\
\text { immune function after ovarian serous } \\
\text { adenocarcinoma surgery. }\end{array}$ \\
\hline $\begin{array}{l}\text { General Issues } \\
\text { Presentation }\end{array}$ & $\begin{array}{l}\text { Was the report well- } \\
\text { written, organized, and } \\
\text { sufficiently detailed for } \\
\text { critical analysis? } \\
\text { In intervention studies, } \\
\text { was a CONSORT } \\
\text { flowchart provided to } \\
\text { show the flow of } \\
\text { participants in the } \\
\text { study? }\end{array}$ & $\begin{array}{l}\text { - The report was well written and } \\
\text { organizes with an easy flow and a } \\
\text { detailed critical analysis. } \\
\text { A consort flowchart was provided to } \\
\text { show the flow of participants in the } \\
\text { study. Two hundred and thirty-four } \\
\text { patients had initially undergone } \\
\text { ovarian serous adenocarcinoma } \\
\text { surgery, } 30 \text { were lost to follow up, } 56 \\
\text { had inadequate documentation of } \\
\text { medical records, } 5 \text { died from other } \\
\text { causes unrelated to the study. }\end{array}$ \\
\hline $\begin{array}{l}\text { General Issues } \\
\text { Presentation } \\
\text { (continued) }\end{array}$ & $\begin{array}{l}\text { Was the report written } \\
\text { in a manner that makes } \\
\text { the findings accessible } \\
\text { to practicing nurses? }\end{array}$ & $\begin{array}{l}\text { The report was written to provide } \\
\text { current evidence and background } \\
\text { literature for support. Findings are } \\
\text { accessible to practicing nurses as a } \\
\text { reference but not as a definitive } \\
\text { guide. }\end{array}$ \\
\hline $\begin{array}{l}\text { Researcher } \\
\text { credibility }\end{array}$ & $\begin{array}{l}\text { Do the researchers' } \\
\text { clinical, substantive, or } \\
\text { methodological } \\
\text { qualifications and } \\
\text { experience enhance } \\
\text { confidence in the } \\
\text { findings and their } \\
\text { interpretation? }\end{array}$ & $\begin{array}{l}\text { The qualifications of the researchers } \\
\text { do add confidence in the findings and } \\
\text { provide strength to the rational of } \\
\text { their interpretations. Researchers are } \\
\text { associated with the Department of } \\
\text { Anesthesia Cancer Center and } \\
\text { Department of Gynecology. }\end{array}$ \\
\hline $\begin{array}{l}\text { Summary } \\
\text { assessment }\end{array}$ & $\begin{array}{l}\text { Despite any limitations, } \\
\text { do the study findings } \\
\text { appear to be valid-do } \\
\text { you have confidence in } \\
\text { the truth value of the } \\
\text { results? } \\
\text { Does the study } \\
\text { contribute any } \\
\text { meaningful evidence }\end{array}$ & $\begin{array}{l}\text { The study contributes meaningful } \\
\text { evidence; however, the authors } \\
\text { identify the need for a randomized } \\
\text { study with equal sample sizes to } \\
\text { provide a clear, distinct relationship } \\
\text { of anesthesia technique. }\end{array}$ \\
\hline
\end{tabular}




\begin{tabular}{|l|l|l|}
\hline & $\begin{array}{l}\text { that can be used in } \\
\text { nursing practice or that } \\
\text { is useful to the nursing } \\
\text { discipline? }\end{array}$ & \\
\hline
\end{tabular}

Note. $\mathrm{EA}=$ epidural anesthesia (EA); GA= general anesthesia; $\mathrm{PCA}=$ patient-controlled analgesia, $\mathrm{HR}=$ hazard ratio; $\mathrm{NK}=$ natural killer 


\section{Appendix A-4}

Cummings, Xu, Cummings, and Copper. (2012). A Comparison of Epidural Analgesia and Traditional Pain Management Effects on Survival and Cancer Recurrence after Colectomy: A Population-based Study

\begin{tabular}{|c|c|c|}
\hline $\begin{array}{c}\text { Aspect of the } \\
\text { Report }\end{array}$ & Critiquing Questions & Detailed Critiquing Guidelines \\
\hline Title & $\begin{array}{l}\text { Is the title a good one, } \\
\text { succinctly suggesting } \\
\text { key variables and the } \\
\text { study population? }\end{array}$ & $\begin{array}{l}\text { The title of this study was concise } \\
\text { and clearly stated what the authors } \\
\text { were studying. Key aspects of the } \\
\text { study were included. Central topics } \\
\text { were clearly identifiable. The study } \\
\text { population was included. }\end{array}$ \\
\hline Abstract & $\begin{array}{l}\text { Did the abstract clearly } \\
\text { and concisely } \\
\text { summarize the main } \\
\text { features of the report } \\
\text { (problem, methods, } \\
\text { results, conclusions)? }\end{array}$ & $\begin{array}{l}\text { The abstract was written with } \\
\text { subheadings- background, methods, } \\
\text { results and conclusion. The abstract } \\
\text { was brief but clearly described the } \\
\text { reason for the study and the major } \\
\text { aspects of the study for readers to } \\
\text { browse and understand clearly what } \\
\text { the study was about. }\end{array}$ \\
\hline $\begin{array}{l}\text { Introduction } \\
\text { Statement of } \\
\text { the problem }\end{array}$ & $\begin{array}{l}\text { Was the problem stated } \\
\text { unambiguously, and was } \\
\text { it easy to identify? } \\
\text { Is the problem statement } \\
\text { build a persuasive } \\
\text { argument for the new } \\
\text { study? } \\
\text { Was there a good match } \\
\text { between the research } \\
\text { problem and the } \\
\text { methods used -that is, } \\
\text { was a quantitative } \\
\text { approach appropriate? }\end{array}$ & $\begin{array}{l}\text { - The problem of cancer recurrence } \\
\text { after surgery is stated } \\
\text { unambiguously. Colorectal cancer } \\
\text { was identified as the third most } \\
\text { common cancer diagnosed in the US } \\
\text { and accounted for 9\% of all U.S } \\
\text { cancer deaths (Cummings et al., } \\
\text { 2012). The factors including surgical } \\
\text { stress, anesthetic drugs, and opioids } \\
\text { were identified as a major cause of } \\
\text { immunosuppression. } \\
\text { This study compared survival and } \\
\text { cancer recurrence rates for resection } \\
\text { of colorectal cancer between patients } \\
\text { who received epidurals and those } \\
\text { who did not. } \\
\text { The problem statement built a } \\
\text { convincing argument for a new } \\
\text { study; identifying the valuable use of } \\
\text { regional anesthesia and its } \\
\text { association with lower recurrence } \\
\text { rates of breast and prostate cancer. } \\
\text { The results for colon cancer are } \\
\text { mixed encouraging the need for } \\
\text { additional research. }\end{array}$ \\
\hline
\end{tabular}




\begin{tabular}{|c|c|c|}
\hline $\begin{array}{l}\text { Hypotheses or } \\
\text { research } \\
\text { questions }\end{array}$ & $\begin{array}{l}\text { Were research questions } \\
\text { and/or hypotheses } \\
\text { explicitly stated? If not, } \\
\text { was their absence } \\
\text { justified? } \\
\text { Were questions and } \\
\text { hypotheses appropriately } \\
\text { worded, with clear } \\
\text { specification of key } \\
\text { variables and the study } \\
\text { population? } \\
\text { Were the } \\
\text { questions/hypotheses } \\
\text { consistent with existing } \\
\text { knowledge? }\end{array}$ & $\begin{array}{l}\text { - The study included a clear } \\
\text { hypothesis; epidural anesthesia } \\
\text { and/or analgesia are associated with } \\
\text { reduced cancer recurrence after } \\
\text { colorectal cancer resection and } \\
\text { improved all-cause mortality after } \\
\text { surgery. } \\
\text { The hypothesis is consistent with } \\
\text { previous knowledge; however, some } \\
\text { existing knowledge has found no } \\
\text { evidence of this and others oppose it. } \\
\text { Justification for this study included } \\
\text { the need for a larger sample for } \\
\text { adequate results. }\end{array}$ \\
\hline $\begin{array}{l}\text { Literature } \\
\text { review }\end{array}$ & $\begin{array}{l}\text { Was the literature review } \\
\text { up-to-date and based } \\
\text { mainly on primary } \\
\text { sources? } \\
\text { Did the review provide a } \\
\text { state-of-the-art synthesis } \\
\text { of evidence on the } \\
\text { problem? } \\
\text { Did the literature review } \\
\text { provide a strong basis } \\
\text { for the new study? }\end{array}$ & $\begin{array}{l}\text { - The literature review was up-to-date } \\
\text { including primary sources from } \\
\text { 1997-2010. } \\
\text { The review provided the reader with } \\
\text { an understanding of colorectal cancer } \\
\text { and the impacts of certain factors on } \\
\text { immunosuppression including, } \\
\text { surgical factors, allogeneic blood } \\
\text { transfusions, and general anesthesia. } \\
\text { Cummings et al. (2012) identify with } \\
\text { previous studies, regional anesthetic } \\
\text { techniques and their association with } \\
\text { lower recurrence rates of breast and } \\
\text { prostate cancers. The results for } \\
\text { colon cancer are mixed, encouraging } \\
\text { the need for a larger database } \\
\text { analyses as prospective trials are } \\
\text { conducted. }\end{array}$ \\
\hline $\begin{array}{l}\text { Conceptual/ } \\
\text { theoretical } \\
\text { framework }\end{array}$ & $\begin{array}{l}\text { Were key concepts } \\
\text { adequately defined } \\
\text { conceptually? } \\
\text { Was a } \\
\text { conceptual/theoretical } \\
\text { framework articulated- } \\
\text { and, if so, was it } \\
\text { appropriate? If not, is } \\
\text { the absence of a } \\
\text { framework justified? }\end{array}$ & $\begin{array}{l}\text { Key concepts of epidural anesthesia } \\
\text { use and non-use for colorectal } \\
\text { patients receiving a colectomy were } \\
\text { defined. } \\
\text { - A population-based study using the } \\
\text { Medicare database was used. } \\
\text { - No framework was articulated for } \\
\text { this study. }\end{array}$ \\
\hline
\end{tabular}




\begin{tabular}{|c|c|c|}
\hline $\begin{array}{l}\text { Method } \\
\text { Protection of } \\
\text { human rights }\end{array}$ & $\begin{array}{l}\text { Were appropriate } \\
\text { procedures used to safe- } \\
\text { guard the rights of study } \\
\text { participants? } \\
\text { Was the study externally } \\
\text { reviewed by an } \\
\text { IRB/ethics review } \\
\text { board? } \\
\text { Was the study designed } \\
\text { to minimize risks and } \\
\text { maximize benefits to } \\
\text { participants? }\end{array}$ & $\begin{array}{l}\text { The Medicare-SEER database search } \\
\text { for colorectal cancer patients was } \\
\text { used and approved by Case } \\
\text { Comprehensive Cancer Center } \\
\text { Institutional Review Board } \\
\text { (Cleveland, Ohio) and the National } \\
\text { Cancer Institute (Bethesda, } \\
\text { Maryland). } \\
\text { - SEER Medicare database was used } \\
\text { to compare overall survival and } \\
\text { cancer recurrence of patients who } \\
\text { did/did not receive epidural } \\
\text { anesthesia and/or analgesia for } \\
\text { resection of non-metastatic colorectal } \\
\text { cancer. } \\
\text { The population cohort study was } \\
\text { designed to reduce risks to patients, } \\
\text { and to improve the future use of } \\
\text { anesthesia use for the colorectal } \\
\text { patient. }\end{array}$ \\
\hline $\begin{array}{l}\text { Research } \\
\text { design }\end{array}$ & $\begin{array}{l}\text { Was the most rigorous } \\
\text { design used, given the } \\
\text { study purpose? } \\
\text { Were appropriate } \\
\text { comparisons made to } \\
\text { enhance interpretability } \\
\text { of the findings? } \\
\text { Was the number of data } \\
\text { collection points } \\
\text { appropriate? } \\
\text { Did the design minimize } \\
\text { biases and threats to the } \\
\text { internal, construct, and } \\
\text { external validity of the } \\
\text { study (e.g., was blinding } \\
\text { used, was attrition } \\
\text { minimized)? }\end{array}$ & $\begin{array}{l}\text { - A population cohort study was a } \\
\text { good choice for this study. The } \\
\text { population-based study is selected } \\
\text { for a longitudinal assessment to } \\
\text { expose outcomes. The justification } \\
\text { for this study is its external validity } \\
\text { (the applicability to colorectal cancer } \\
\text { patients). The cohort study is } \\
\text { adequate for the large sample size. } \\
\text { The SEER tumor registry provides a } \\
\text { population-based source of } \\
\text { information about patients with } \\
\text { colorectal cancer. The SEER data } \\
\text { includes; primary site of the cancer, } \\
\text { previous cancer diagnoses, histology, } \\
\text { tumor stage, site specific surgery, } \\
\text { reasons patients did not undergo } \\
\text { surgery, surgery of distant sites, and } \\
\text { initial course of therapy. }\end{array}$ \\
\hline $\begin{array}{l}\text { Population and } \\
\text { sample }\end{array}$ & $\begin{array}{l}\text { Was the population } \\
\text { identified? Was the } \\
\text { sample described in } \\
\text { sufficient detail? } \\
\text { Was the best possible }\end{array}$ & $\begin{array}{l}\text { The population of interest included } \\
\text { patients aged } 66 \text { years or older } \\
\text { diagnosed with non-metastatic } \\
\text { colorectal adenocarcinoma who } \\
\text { underwent surgical intervention } \\
\text { between the dates } 1996 \text { and } 2005 \text {. }\end{array}$ \\
\hline
\end{tabular}




\begin{tabular}{|c|c|c|}
\hline & $\begin{array}{l}\text { sampling design used to } \\
\text { enhance the sample's } \\
\text { representativeness? } \\
\text { Were sampling biases } \\
\text { minimized? } \\
\text { Was the sample size } \\
\text { based on a power } \\
\text { analysis? }\end{array}$ & $\begin{array}{l}\text { This time frame allowed for } 4 \text { years } \\
\text { of follow-up for cancer recurrence. } \\
\text { Patients aged } 66 \text { years or older were } \\
\text { included who presented with local or } \\
\text { regional stage disease (Stages I, II, } \\
\text { and III) according to SEER and those } \\
\text { who underwent a colectomy within } 6 \\
\text { months of diagnosis. } \\
\text { - } \text { Inclusion and exclusion criteria was } \\
\text { provided. Sample size was based on } \\
\text { a power analysis, original cohort } \\
\text { included 357,137 patients. After } \\
\text { exclusions, study included a primary } \\
\text { sample of 42,151 patients, and } \\
\text { analysis sample of 40,377. }\end{array}$ \\
\hline $\begin{array}{l}\text { Data } \\
\text { collection and } \\
\text { measurement }\end{array}$ & $\begin{array}{l}\text { Were the operational and } \\
\text { conceptual definitions } \\
\text { congruent? } \\
\text { Were key variables } \\
\text { measured using an } \\
\text { appropriate method (e.g., } \\
\text { interviews, observations, } \\
\text { and so on)? } \\
\text { Were specific } \\
\text { instruments adequately } \\
\text { described and were they } \\
\text { good choices, given the } \\
\text { study population and the } \\
\text { variables being studied? } \\
\text { Did the report provide } \\
\text { evidence that the data } \\
\text { collection methods } \\
\text { yielded data that were } \\
\text { reliable, valid and } \\
\text { responsive? }\end{array}$ & $\begin{array}{l}\text { Conceptual definitions were defined } \\
\text { and congruent. } \\
\text { Variables measured included- } \\
\text { Exposure. Type of anesthetic- } \\
\text { epidural analgesia/analgesia use or } \\
\text { none. } \\
\text { Outcome. All-cause mortality after } \\
\text { cancer resection determined by the } \\
\text { date of death, secondary outcome } \\
\text { was colorectal cancer recurrence, } \\
\text { recurrence within a 4-yr window } \\
\text { after surgery, receipt of } \\
\text { chemotherapy } 16 \text { months or more } \\
\text { after the date of surgery and/or } \\
\text { radiation therapy } 12 \text { months or more } \\
\text { after the date of surgery were also } \\
\text { measured, radiation therapy was also } \\
\text { included. } \\
\text { Covariates. Included patient } \\
\text { demographic and clinical variables } \\
\text { including age, gender, race, marital } \\
\text { status, SEER site, year of diagnosis, } \\
\text { anatomical site, stage of disease at } \\
\text { diagnosis, and date of death. } \\
\text { Socioeconomic factors anatomical } \\
\text { tumor site was included, and blood } \\
\text { transfusions. } \\
\text { Colectomy. They examined } \\
\text { MedPAR for surgical procedure }\end{array}$ \\
\hline
\end{tabular}




\begin{tabular}{|c|c|c|}
\hline & & $\begin{array}{l}\text { codes. } \\
\text { Complications. To account for } \\
\text { differences in perioperative } \\
\text { complications, Medicare claims data } \\
\text { was searched from surgery date until } \\
30 \text { days after surgery. Complications } \\
\text { included retrieval of retained foreign } \\
\text { body, management of postoperative } \\
\text { shock/hemorrhage, management of } \\
\text { abdominal infection, repair of an } \\
\text { organ injury/laceration, reoperative } \\
\text { laparotomy, management of wound } \\
\text { complication, management of fistula. } \\
\text { Evidence provided was reliable } \\
\text { responsive data. }\end{array}$ \\
\hline Procedures & $\begin{array}{l}\text { If there was an } \\
\text { intervention, was it } \\
\text { adequately described, } \\
\text { and was it rigorously } \\
\text { developed and } \\
\text { implemented? Did most } \\
\text { participants allocated to } \\
\text { the intervention group } \\
\text { actually receive it? Was } \\
\text { there evidence of } \\
\text { intervention fidelity? } \\
\text { Were data collected in a } \\
\text { manner that minimized } \\
\text { bias? Were the staff } \\
\text { who collected data } \\
\text { appropriately trained? }\end{array}$ & 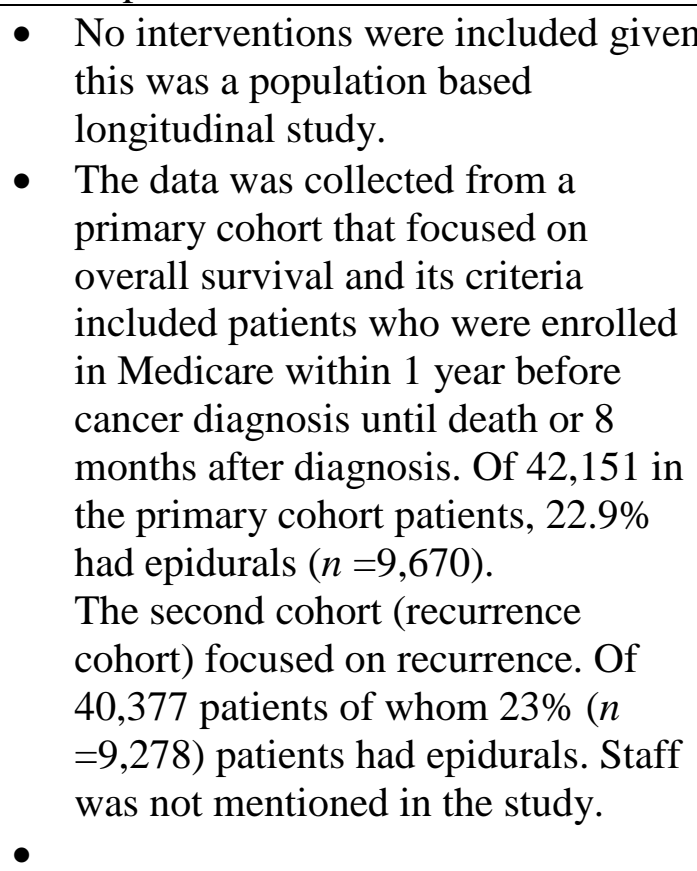 \\
\hline Data Analysis & $\begin{array}{l}\text { Were analyses } \\
\text { undertaken to address } \\
\text { each research question } \\
\text { or test each hypothesis? } \\
\text { Were appropriate } \\
\text { statistical methods used, } \\
\text { given the level of } \\
\text { measurement of the } \\
\text { variables, number of } \\
\text { groups being compared, } \\
\text { and assumptions of the }\end{array}$ & $\begin{array}{l}\text { Statistical Analysis of patient } \\
\text { characteristics were compared } \\
\text { according to the presence or absence } \\
\text { of epidural anesthesia/analgesia. } \\
\text { - } \quad \text { Pearson's chi-square test was used to } \\
\text { compare groups. } \\
\text { - Wilcoxon rank sum test were used to } \\
\text { compare the groups. } \\
\text { - Survival time was defined from the } \\
\text { date of surgery to all-cause mortality } \\
\text { or last follow-up through December } \\
\text { 31, 2009. Kaplan-Meier survival }\end{array}$ \\
\hline
\end{tabular}




\begin{tabular}{|c|c|c|}
\hline & $\begin{array}{l}\text { texts? } \\
\text { Was a powerful analytic } \\
\text { method used? (e.g., did } \\
\text { the analysis help to } \\
\text { control for confounding } \\
\text { variables)? } \\
\text { Were type I and Type II } \\
\text { errors avoided or } \\
\text { minimized? } \\
\text { In intervention studies, } \\
\text { was an intention-to-treat } \\
\text { analysis performed? }\end{array}$ & $\begin{array}{l}\text { curves were generated, and group } \\
\text { comparison was based on the log- } \\
\text { rank test. } \\
\text { A marginal Cox model was } \\
\text { constructed. Propensity score was } \\
\text { used as a continuous covariate to be } \\
\text { included in the survival models. } \\
\text { - A conditional logistic regression } \\
\text { was used to predict the likelihood of } \\
\text { cancer recurrence, controlling for } \\
\text { hospital effect. } \\
\text { All data were analyzed using SAS } \\
\text { software version 9.2 (SAS Institute, } \\
\text { Cary, NC) and R 2.9.2. } \\
\text { All comparisons used two-sided tests } \\
\text { at a significance level of 0.05. }\end{array}$ \\
\hline $\begin{array}{l}\text { Data Analysis } \\
\text { (continued) }\end{array}$ & $\begin{array}{l}\text { Were problems of } \\
\text { missing values evaluated } \\
\text { and adequately } \\
\text { addressed? }\end{array}$ & $\begin{array}{l}\text { Problems of missing information was } \\
\text { addressed in the limitations section } \\
\text { of the study, see below. }\end{array}$ \\
\hline Findings & $\begin{array}{l}\text { Was information about } \\
\text { statistical significance } \\
\text { presented? Was } \\
\text { information about effect } \\
\text { size and precision of } \\
\text { estimates (confidence } \\
\text { intervals) presented? } \\
\text { Were the findings } \\
\text { adequately summarized, } \\
\text { with good use of tables } \\
\text { and figures? } \\
\text { Were findings reported } \\
\text { in a manner that } \\
\text { facilitates a meta- } \\
\text { analysis, and with } \\
\text { sufficient information } \\
\text { needed for EBP? }\end{array}$ & $\begin{array}{l}\text { - Information about statistical } \\
\text { significance was presented. Effect } \\
\text { size and confidence intervals were } \\
\text { presented. } \\
\text { - The findings were adequately } \\
\text { summarized with good figures. } \\
\text { - Association between epidural and } \\
\text { overall survival was evaluated. } \\
\text { - Kaplan-Meier survival curves for the } \\
\text { two groups; the curves were } \\
\text { significantly different (log-rank test } p \\
\text { < 0.001). } \\
\text { The association between epidural use } \\
\text { and colorectal cancer recurrence was } \\
\text { also evaluated. } \\
\text {. }\end{array}$ \\
\hline $\begin{array}{l}\text { Discussion } \\
\text { Interpretation } \\
\text { of the findings }\end{array}$ & $\begin{array}{l}\text { Were all major findings } \\
\text { interpreted and } \\
\text { discussed within the } \\
\text { context of prior research } \\
\text { and/or the study's } \\
\text { conceptual framework? }\end{array}$ & $\begin{array}{l}\text { - All major findings were interpreted } \\
\text { and discussed. } \\
\text { - Results suggest early beneficial } \\
\text { effects of epidural use on all } \\
\text { mortality after colorectal resection } \\
\text { for cancer. }\end{array}$ \\
\hline
\end{tabular}









\begin{tabular}{|c|c|c|}
\hline & & $\begin{array}{l}\text { limited clinical data such as other } \\
\text { surgical and anesthesia techniques, } \\
\text { and other drugs administered. } \\
\text { Timing of epidural placement was } \\
\text { not clear and placement time is } \\
\text { skewed for this report. } \\
\text { - Generalizability was not discussed. }\end{array}$ \\
\hline $\begin{array}{l}\text { Implications/ } \\
\text { recommendati- } \\
\text { ons }\end{array}$ & $\begin{array}{l}\text { Did the researchers } \\
\text { discuss the implications } \\
\text { of the study for clinical } \\
\text { practice or further } \\
\text { research—and were } \\
\text { those implications } \\
\text { reasonable and } \\
\text { complete? }\end{array}$ & $\begin{array}{l}\text { - Cummings et al. (2012) concluded } \\
\text { the large population-based cohort } \\
\text { study suggested that epidural } \\
\text { anesthesia/analgesia was associated } \\
\text { with improved survival in patients } \\
\text { with non-metastatic colorectal cancer } \\
\text { undergoing resection. The results did } \\
\text { not support an association between } \\
\text { epidural anesthesia/analgesia and } \\
\text { recurrent disease. } \\
\text { - Prospective studies are needed to } \\
\text { determine whether the association } \\
\text { between epidural use and survival is } \\
\text { causative. }\end{array}$ \\
\hline $\begin{array}{l}\text { General } \\
\text { Issues } \\
\text { Presentation }\end{array}$ & $\begin{array}{l}\text { Was the report well- } \\
\text { written, organized, and } \\
\text { sufficiently detailed for } \\
\text { critical analysis? } \\
\text { In intervention studies, } \\
\text { was a CONSORT } \\
\text { flowchart provided to } \\
\text { show the flow of } \\
\text { participants in the study? }\end{array}$ & $\begin{array}{l}\text { This analysis was organized, very } \\
\text { detail oriented and well written for a } \\
\text { critical analysis }\end{array}$ \\
\hline $\begin{array}{l}\text { General } \\
\text { Issues } \\
\text { Presentation } \\
\text { (continued) }\end{array}$ & $\begin{array}{l}\text { Was the report written in } \\
\text { a manner that makes the } \\
\text { findings accessible to } \\
\text { practicing nurses? }\end{array}$ & $\begin{array}{l}\text { - This report was written in an } \\
\text { organized, and easily understandable } \\
\text { manner allowing for easy access to } \\
\text { findings and results for practicing } \\
\text { nurses. }\end{array}$ \\
\hline $\begin{array}{l}\text { Researcher } \\
\text { credibility }\end{array}$ & $\begin{array}{l}\text { Do the researchers' } \\
\text { clinical, substantive, or } \\
\text { methodologic } \\
\text { qualifications and } \\
\text { experience enhance } \\
\text { confidence in the } \\
\text { findings and their } \\
\text { interpretation? }\end{array}$ & $\begin{array}{l}\text { Researchers include an Assistant } \\
\text { Professor of Anesthesiology and } \\
\text { Outcomes Research, from the } \\
\text { Anesthesiology Institute, Cleveland } \\
\text { Clinic, a Statistical Analyst, } \\
\text { Digestive Health Research Center, } \\
\text { Case Western Reserve University, an } \\
\text { Assistant Professor of Medicine, and } \\
\text { a Professor of Medicine, Division of } \\
\text { Gastroenterology and Liver Disease, }\end{array}$ \\
\hline
\end{tabular}




\begin{tabular}{|c|c|c|}
\hline & & $\begin{array}{l}\text { Department of Medicine, University } \\
\text { Hospitals Case Medical Center, (all } \\
\text { Cleveland, Ohio) } \\
\text { - The qualification and experience do } \\
\text { enhance confidence in the finding } \\
\text { and interpretations of this article. }\end{array}$ \\
\hline $\begin{array}{l}\text { Summary } \\
\text { assessment }\end{array}$ & $\begin{array}{l}\text { Despite any limitations, } \\
\text { do the study findings } \\
\text { appear to be valid--do } \\
\text { you have confidence in } \\
\text { the truth value of the } \\
\text { results? } \\
\text { Does the study } \\
\text { contribute any } \\
\text { meaningful evidence } \\
\text { that can be used in } \\
\text { nursing practice or that } \\
\text { is useful to the nursing } \\
\text { discipline? }\end{array}$ & $\begin{array}{l}\text { The study identified the benefits of } \\
\text { epidural anesthesia regardless of } \\
\text { placement time for colorectal patient } \\
\text { undergoing resection. } \\
\text { - The research appears to be valid with } \\
\text { appropriate utilization of } \\
\text { measurements including statistical } \\
\text { analysis and logistic regression to } \\
\text { name a few. }\end{array}$ \\
\hline
\end{tabular}




\section{Appendix A-5}

Chen, and Miao. (2013). The effect of anesthetic technique on survival in human cancers: A Meta-analysis of Retrospective and Prospective Studies

\begin{tabular}{|c|c|c|}
\hline $\begin{array}{l}\text { Aspect of the } \\
\text { Report }\end{array}$ & Critiquing Questions & Detailed Critiquing Guidelines \\
\hline Title & $\begin{array}{l}\text { Is the title a good one, } \\
\text { succinctly suggesting } \\
\text { key variables and the } \\
\text { study population? }\end{array}$ & $\begin{array}{l}\text { The title is brief without a specific } \\
\text { identification of the type of } \\
\text { anesthetics that are under review. A } \\
\text { brief anesthetic technique phase is } \\
\text { utilized in the title, rather than } \\
\text { identifying the individual types being } \\
\text { examined. }\end{array}$ \\
\hline Abstract & $\begin{array}{l}\text { Did the abstract clearly } \\
\text { and concisely } \\
\text { summarize the main } \\
\text { features of the report } \\
\text { (problem, methods, } \\
\text { results, conclusions)? }\end{array}$ & $\begin{array}{l}\text { The abstract is clearly written with a } \\
\text { concise summary of the problem, } \\
\text { methods for the analysis, results, and } \\
\text { conclusions. }\end{array}$ \\
\hline $\begin{array}{l}\text { Introduction } \\
\text { Statement of } \\
\text { the problem }\end{array}$ & $\begin{array}{l}\text { Were authors' } \\
\text { affiliations provided? } \\
\text { Did the review have } \\
\text { support of at least } 2 \\
\text { authors? } \\
\text { Was the study objective } \\
\text { \& rationale given? } \\
\text { Terms defined? } \\
\text { Was there enough } \\
\text { information on the } \\
\text { population studied, the } \\
\text { intervention given and } \\
\text { the outcomes considered }\end{array}$ & $\begin{array}{l}\text { - Two Authors completed this meta- } \\
\text { analysis. Chen and Miao are affiliated } \\
\text { with the department of } \\
\text { Anesthesiology at the Shanghai } \\
\text { Cancer Center and Cancer institute at } \\
\text { the Shanghai Medical College at } \\
\text { Fudan University. } \\
\text { - The meta-analysis was performed to } \\
\text { test the hypothesis that patients with } \\
\text { cancer who underwent surgical } \\
\text { intervention under epidural anesthesia } \\
\text { (EA) vs. those who underwent } \\
\text { general anesthesia (GA) would have } \\
\text { better outcomes. } \\
\text { The study objective and rationale for } \\
\text { analysis are clearly stated and terms } \\
\text { are defined. }\end{array}$ \\
\hline $\begin{array}{l}\text { Hypotheses } \\
\text { or research } \\
\text { questions }\end{array}$ & $\begin{array}{l}\text { Is the main question or } \\
\text { problem clear and } \\
\text { focused? PICO format } \\
\text { used? }\end{array}$ & $\begin{array}{l}\text { - The main questions are used in a } \\
\text { PICO format and is clear with a } \\
\text { specific focus. }\end{array}$ \\
\hline $\begin{array}{l}\text { Literature } \\
\text { Review }\end{array}$ & $\begin{array}{l}\text { Was the literature review } \\
\text { up-to-date and based } \\
\text { mainly on primary }\end{array}$ & $\begin{array}{l}\text { - The literature of } 14 \text { primary studies } \\
\text { were reviewed. The review was } \\
\text { published February 20,2013 and the }\end{array}$ \\
\hline
\end{tabular}




\begin{tabular}{|c|c|c|}
\hline & $\begin{array}{l}\text { sources? } \\
\text { Did the review provide a } \\
\text { state-of-the-art synthesis } \\
\text { of evidence on the } \\
\text { problem? } \\
\text { Did the literature review } \\
\text { provide a strong basis } \\
\text { for the new study? }\end{array}$ & $\begin{array}{l}\text { knowledge was up-to-date. } \\
\text { Authors provide the audience with a } \\
\text { brief understanding of EA benefits } \\
\text { including pain relief, decrease } \\
\text { incidence of side effects, and the } \\
\text { proposed benefit of decrease of } \\
\text { attenuation of the immune response. } \\
\text { - } \text { Identification of the impact of the } \\
\text { surgical stress response on the } \\
\text { immune system and the impact of } \\
\text { opioid induced immune suppression } \\
\text { were investigated. The authors } \\
\text { believe regional anesthetic techniques } \\
\text { could cause less immune suppression } \\
\text { compared to GA and opioid } \\
\text { analgesia. } \\
\text { Studies have identified relationships } \\
\text { between improved outcomes after } \\
\text { surgical intervention for cancer and } \\
\text { regional anesthesia use, and some } \\
\text { have not. } \\
\text { The literature review provides a } \\
\text { mediocre basis for a new study. } \\
\text { To improve the authors hypothesis of } \\
\text { an association with decreased cancer } \\
\text { recurrence after surgical intervention } \\
\text { with the use of EA, this meta-analysis } \\
\text { was performed. }\end{array}$ \\
\hline $\begin{array}{l}\text { Search } \\
\text { Criteria } \\
\text { Methods }\end{array}$ & $\begin{array}{l}\text { Please describe the } \\
\text { search criteria the } \\
\text { authors used. } \\
\text { Inclusion / exclusion } \\
\text { criteria listed. Was there } \\
\text { enough information on } \\
\text { the population studied, } \\
\text { the intervention given, } \\
\text { and the outcomes } \\
\text { considered? } \\
\text { Comprehensive, } \\
\text { systematic search used? } \\
\text { Explicit criteria listed? } \\
\text { Search terms and } \\
\text { databases used? grey } \\
\text { literature discussion? }\end{array}$ & $\begin{array}{l}\text { - The search criteria from included } \\
\text { Web of Science database, PubMed, } \\
\text { and Medline. } \\
\text { - Search terms included; } \\
\text { regional/epidural anesthesia, general } \\
\text { anesthesia, anesthetic technique, } \\
\text { metastasis, recurrence, survival and } \\
\text { cancer/carcinoma. } \\
\text { - Inclusion criteria included; published } \\
\text { in English, with abstract or full text } \\
\text { paper, comparison of EA vs. GA on } \\
\text { survival or recurrence in cancer } \\
\text { surgery, prospective or retrospective } \\
\text { studies, data with hazard ratio (HR) } \\
\text { and 95\% confidence intervals (CI). } \\
\text { Exclusion criteria included; } \\
\text { experimental studies, not comparing } \\
\text { EA and GA, not for survival or }\end{array}$ \\
\hline
\end{tabular}




\begin{tabular}{|c|c|c|}
\hline & $\begin{array}{l}\text { Is it likely that all } \\
\text { relevant studies } \\
\text { (published and } \\
\text { unpublished) were } \\
\text { identified? }\end{array}$ & $\begin{array}{l}\text { recurrence, unavailable HR and 95\% } \\
\text { CI. } \\
731 \text { articles were located for research. } \\
135 \text { articles with abstracts were } \\
\text { identified as potentially eligible. } \\
\text { - } \quad \text { After all full text reviews were } \\
\text { completed, }(n=14) \text { studies were } \\
\text { considered eligible for the meta- } \\
\text { analysis. }\end{array}$ \\
\hline Framework & $\begin{array}{l}\text { Did authors use a model } \\
\text { or guideline for SRs and } \\
\text { inclusive of the model } \\
\text { they used? }\end{array}$ & $\begin{array}{l}\text { - The PRIMSA flowchart was utilized } \\
\text { by the authors. } \\
\text { - The meta-analysis and the systematic } \\
\text { review adhered to all standards for } \\
\text { quality reporting. }\end{array}$ \\
\hline $\begin{array}{l}\text { Included } \\
\text { studies }\end{array}$ & $\begin{array}{l}\text { Was sufficient } \\
\text { information given on } \\
\text { chosen studies to } \\
\text { determine validity of the } \\
\text { research? } \\
\text { Were PICO and } \\
\text { methodological quality } \\
\text { of each study addressed } \\
\text { in table format? Did the } \\
\text { authors critically } \\
\text { appraise each study? } \\
\text { Were the criteria used to } \\
\text { select articles for } \\
\text { inclusion predetermined, } \\
\text { clearly stated, and } \\
\text { appropriate? }\end{array}$ & $\begin{array}{l}\text { - All studies were reviewed by two } \\
\text { authors independently. Variables } \\
\text { taken from each study included; } \\
\text { authors, year of publication, type of } \\
\text { cancer, design, EA group total, HR, } \\
\text { 95\% CI for outcomes of treatment. } \\
\text { - HR, 95\% CI was taken from each to } \\
\text { identify an association between the } \\
\text { outcomes of survival and EA use. } \\
\text { - To assess the quality of the study, the } \\
\text { 9-star Newcastle-Ottawa Scale was } \\
\text { used. } \\
\text { To assess heterogeneity the use of } \\
\text { Cochran chi-squared Q squared, and } \\
\text { I-squared statistics were used. } \\
\text { To assess publication bias, authors } \\
\text { used a funnel plot of ln vs. standard } \\
\text { error. } \\
\text { The use of Egger's test was used to } \\
\text { test degree of symmetry of study. } \\
\text { A sensitivity analysis to find potential } \\
\text { outliers and thus were omitted if } \\
\text { found. } \\
\text { Stata/SE version } 10.0 \text { was used for all } \\
\text { statistical analyses. } \\
\text { Criteria used was predetermined, } \\
\text { clear and appropriate. }\end{array}$ \\
\hline Results: & $\begin{array}{l}\text { Were results of review } \\
\text { clearly described in a } \\
\text { critical fashion? In table } \\
\text { and narrative? }\end{array}$ & $\begin{array}{l}\text { - } \begin{array}{l}\text { Results were provided in a critical } \\
\text { fashion including tables and narrative } \\
\text { form. }\end{array} \\
\text { - Search flowchart identified the } 14\end{array}$ \\
\hline
\end{tabular}




\begin{tabular}{|c|c|c|}
\hline & $\begin{array}{l}\text { Were results similar } \\
\text { across studies? Was a } \\
\text { cross-analysis } \\
\text { performed? } \\
\text { Are the results of all } \\
\text { included studies clearly } \\
\text { displayed? If the study } \\
\text { results were combined, } \\
\text { was it appropriate to do } \\
\text { so? } \\
\text { How precise are the } \\
\text { results? Do the results of } \\
\text { the studies have } \\
\text { significant findings, and } \\
\text { do the researchers } \\
\text { provide evidence of } \\
\text { such? Did the } \\
\text { interpretation of the } \\
\text { review's results } \\
\text { accurately reflect the } \\
\text { actual results? Are } \\
\text { results generalizable? }\end{array}$ & $\begin{array}{l}\text { eligible studies included in this } \\
\text { analysis. } \\
\text { For the EA group, 12,000 cases were } \\
\text { included. For the GA group, 35,000 } \\
\text { cases were included. } \\
\text { - End points that were reviewed } \\
\text { included, recurrence free survival } \\
\text { (RFS- from day of surgery to first } \\
\text { disease relapse from primary cancer) } \\
\text { and overall survival (OS- from day of } \\
\text { surgery until death). } \\
\text { For the OS- } 4 \text { studies showing a } \\
\text { significant relationship between that } \\
\text { of EA and improved OS. } \\
\text { For the RFS- } 11 \text { studies with } \\
\text { numerous cancer types were included } \\
\text { in the meta-analysis. Out of the } 11 \\
\text { studies, } 4 \text { showed positive relation } \\
\text { between improved RFS and EA. } \\
\text { Significant findings were provided, } \\
\text { and authors provide an interpretation } \\
\text { of the result. }\end{array}$ \\
\hline $\begin{array}{l}\text { Meta- } \\
\text { analysis }\end{array}$ & $\begin{array}{l}\text { Was a meta-analysis } \\
\text { performed? Please } \\
\text { describe. } \\
\text { How are meta-analysis } \\
\text { results displayed? } \\
\text { Was a rationale for the } \\
\text { statistics used provided? } \\
\text { Was this cohesive with } \\
\text { what you have learned? } \\
\text { Was statistical } \\
\text { significance tested? }\end{array}$ & $\begin{array}{l}\text { - A meta-analysis was performed, see } \\
\text { above. } \\
\text { Results were displayed in graphs and } \\
\text { narrative form. } \\
\text { - Statistics rationales were performed, } \\
\text { suggesting a positive effect of EA use } \\
\text { on overall survival after surgical } \\
\text { intervention for cancer. } \\
\text { The meta-analysis' findings were } \\
\text { consistent with many other results } \\
\text { from current literature, but there are } \\
\text { still some with that are not. Chen and } \\
\text { Miao, (2013) also identified that the } \\
\text { RFS and EA do not show a beneficial } \\
\text { effect. } \\
\text { Given there were } 5 \text { out of } 7 \text { studies } \\
\text { that were colorectal cancer specific, } \\
\text { another meta-analysis was performed } \\
\text { to identify a correlation between EA } \\
\text { and improved OS. Chen and Miao } \\
\text { (2013) found a positive correlation }\end{array}$ \\
\hline
\end{tabular}




\begin{tabular}{|c|c|c|}
\hline & & $\begin{array}{l}\text { for EA and OS with a HR =0.65, } \\
95 \% \text { CI = [0.43 to 0.99], ( } p=0.045) \text {. } \\
\text { The meta-analysis showed beneficial } \\
\text { evidence on colorectal cancer } \\
\text { surgical patients and the use of EA. } \\
\text { The SEER- surveillance, } \\
\text { epidemiology and result study with } \\
\text { the largest sample size, showed } \\
\text { significant results associated with } \\
\text { colorectal surgical intervention and } \\
\text { EA use on all-cause mortality. The } \\
\text { MASTER trial- prospective study, } \\
\text { did not show significance for surgical } \\
\text { patients of abdominal cancers. }\end{array}$ \\
\hline Discussion & $\begin{array}{l}\text { Was the discussion } \\
\text { section clear and } \\
\text { comprehensive? } \\
\text { What do the main } \\
\text { findings mean } \\
\text { Are the conclusions } \\
\text { justified } \\
\text { How do the findings } \\
\text { compare with what } \\
\text { others have found? } \\
\text { Application of findings } \\
\text { Were limitations } \\
\text { discussed? Implications? }\end{array}$ & $\begin{array}{l}\text { The discussion was clear and } \\
\text { comprehensive. Authors identify } \\
\text { probable cause for results. } \\
\text { Authors acknowledge their analysis } \\
\text { was not able to demonstrate immune } \\
\text { surveillance interventions that } \\
\text { focused on immunosuppression } \\
\text { reduction. } \\
\text { - Authors identify their analysis did not } \\
\text { support a relation between EA and } \\
\text { decreased cancer recurrence. } \\
\text { Authors identify their analysis did } \\
\text { support a relation between EA and } \\
\text { overall survival. } \\
\text { Study limited by non-randomization, } \\
\text { primarily retrospective studies used, } \\
\text { surgical technique differences, } \\
\text { problems with long term follow up, } \\
\text { different patient populations, and } \\
\text { differences among studies of how } \\
\text { recurrence is defined. Other } \\
\text { limitations include; types of cancer } \\
\text { and tumor biology, and English } \\
\text { studies only. } \\
\text { Authors state prospective studies are } \\
\text { needed to find an association between } \\
\text { survival and epidural anesthesia use. }\end{array}$ \\
\hline
\end{tabular}

Note. $\mathrm{RA}=$ regional anesthesia; $\mathrm{EA}=$ epidural anesthesia; $\mathrm{GA}=$ general anesthesia; $\mathrm{CI}=$ confidence interval; $\mathrm{OS}=$ Overall survival; $\mathrm{HR}=$ hazard ratio; $\mathrm{RFS}=$ recurrence free survival 


\section{Appendix A-6}

Jang, Lim, Shin, Kwon Ko, Park, Hyun Song, and June Kim. (2016). A comparison of regional and general anesthesia effects on 5 years survival and cancer recurrence after transurethral resection of the bladder tumor: a retrospective analysis

\begin{tabular}{|c|c|c|}
\hline Title & $\begin{array}{l}\text { Is the title a good one, } \\
\text { succinctly suggesting } \\
\text { key variables and the } \\
\text { study population? }\end{array}$ & $\begin{array}{l}\text { The title for this article } \\
\text { described the key points for } \\
\text { this retrospective analysis. } \\
\text { Central topics, including } \\
\text { regional and general } \\
\text { anesthesia effect on cancer } \\
\text { recurrence, were included. } \\
\text { The title communicated the } \\
\text { intended comparison for the } \\
\text { analysis between regional } \\
\text { anesthesia (RA) and general } \\
\text { anesthesia (GA). The title } \\
\text { identified the population of } \\
\text { concern, cancer patients with } \\
\text { bladder tumors. }\end{array}$ \\
\hline Abstract & $\begin{array}{l}\text { Did the abstract clearly } \\
\text { and concisely } \\
\text { summarize the main } \\
\text { features of the report } \\
\text { (problem, methods, } \\
\text { results, conclusions)? }\end{array}$ & $\begin{array}{l}\text { The abstract for this research } \\
\text { was written clear and concise } \\
\text { with subheadings. The } \\
\text { abstract was clearly labeled } \\
\text { with each important section of } \\
\text { the study, allowing for quick } \\
\text { review of the topic. The } \\
\text { background of the topic was } \\
\text { clear and concise, identifying } \\
\text { the purpose of the study. }\end{array}$ \\
\hline $\begin{array}{l}\text { Introduction } \\
\text { Statement of the } \\
\text { problem }\end{array}$ & $\begin{array}{l}\text { Was the problem stated } \\
\text { unambiguously, and } \\
\text { was it easy to identify? } \\
\text { Is the problem statement } \\
\text { build a persuasive } \\
\text { argument for the new } \\
\text { study? } \\
\text { Was there a good match } \\
\text { between the research } \\
\text { problem and the } \\
\text { methods used -that is, } \\
\text { was a quantitative } \\
\text { approach appropriate? }\end{array}$ & $\begin{array}{l}\text { The introduction to this study } \\
\text { was clear and concise to the } \\
\text { trained professional in } \\
\text { anesthesia. RA was not } \\
\text { defined for the non-medical } \\
\text { professional. The introduction } \\
\text { begins with cancer and } \\
\text { treatments currently in } \\
\text { practice, identifying surgical } \\
\text { intervention as the main } \\
\text { treatment of choice. } \\
\text { The importance of the topic } \\
\text { was not identified, nor was } \\
\text { bladder cancer prevalence. } \\
\text { RA was briefly discussed, }\end{array}$ \\
\hline
\end{tabular}




\begin{tabular}{|c|c|c|}
\hline & & $\begin{array}{l}\text { with reference to a single } \\
\text { research study. }\end{array}$ \\
\hline $\begin{array}{l}\text { Hypotheses or } \\
\text { research questions }\end{array}$ & $\begin{array}{l}\text { Were research questions } \\
\text { and/or hypotheses } \\
\text { explicitly stated? If not, } \\
\text { was their absence } \\
\text { justified? } \\
\text { Were questions and } \\
\text { hypotheses } \\
\text { appropriately worded, } \\
\text { with clear specification } \\
\text { of key variables and the } \\
\text { study population? } \\
\text { Were the } \\
\text { questions/hypotheses } \\
\text { consistent with existing } \\
\text { knowledge? }\end{array}$ & $\begin{array}{l}\text { - The introduction describes } \\
\text { RA as decreasing surgery } \\
\text { induced stress and opioid } \\
\text { requirements, and the belief of } \\
\text { its role in reduction of cancer } \\
\text { recurrence. GA is briefly } \\
\text { discussed and its general role } \\
\text { in the research. } \\
\text { - Jang et al. (2016) collected } \\
\text { data to determine if mortality } \\
\text { after bladder cancer differed } \\
\text { between patients who } \\
\text { underwent surgical } \\
\text { intervention under general } \\
\text { anesthesia (GA) vs. surgical } \\
\text { intervention with regional } \\
\text { anesthesia (RA). }\end{array}$ \\
\hline Literature review & $\begin{array}{l}\text { Was the literature } \\
\text { review up-to-date and } \\
\text { based mainly on } \\
\text { primary sources? } \\
\text { Did the review provide } \\
\text { a state-of-the-art } \\
\text { synthesis of evidence on } \\
\text { the problem? } \\
\text { Did the literature review } \\
\text { provide a strong basis } \\
\text { for the new study? }\end{array}$ & $\begin{array}{l}\text { This study lacked an adequate } \\
\text { literature review, however, the } \\
\text { literature used were mainly } \\
\text { primary sources. The } \\
\text { literature review did not } \\
\text { provide a strong basis for the } \\
\text { new study, especially due to } \\
\text { the lack of statistical support } \\
\text { of bladder cancer prevalence. } \\
\text { The introduction does set up } \\
\text { the study identifying no } \\
\text { current retrospective studies } \\
\text { available on bladder cancer in } \\
\text { early stages (stages I-II). } \\
\text { Further stating the purpose of } \\
\text { the retrospective study, to } \\
\text { investigate which anesthetic } \\
\text { approach results in a better } \\
\text { bladder cancer prognosis. }\end{array}$ \\
\hline $\begin{array}{l}\text { Conceptual/theoretical } \\
\text { framework }\end{array}$ & $\begin{array}{l}\text { Were key concepts } \\
\text { adequately defined } \\
\text { conceptually? } \\
\text { Was a } \\
\text { conceptual/theoretical } \\
\text { framework articulated- } \\
\text { and, if so, was it }\end{array}$ & $\begin{array}{l}\text { Adequate identification of } \\
\text { comparison was made for the } \\
\text { research question. Key } \\
\text { concepts were identified, GA } \\
\text { vs. RA in bladder surgery and } \\
\text { cancer recurrence. } \\
\text { - No theoretical/conceptual } \\
\text { framework was identified. }\end{array}$ \\
\hline
\end{tabular}




\begin{tabular}{|c|c|c|}
\hline & $\begin{array}{l}\text { appropriate? If not, is } \\
\text { the absence of a } \\
\text { framework justified? } \\
\text { Were the questions/ } \\
\text { hypotheses consistent } \\
\text { with the framework? }\end{array}$ & \\
\hline $\begin{array}{l}\text { Method } \\
\text { Protection of human } \\
\text { rights }\end{array}$ & $\begin{array}{l}\text { Were appropriate } \\
\text { procedures used to safe- } \\
\text { guard the rights of study } \\
\text { participants? } \\
\text { Was the study } \\
\text { externally reviewed by } \\
\text { an IRB/ethics review } \\
\text { board? } \\
\text { Was the study designed } \\
\text { to minimize risks and } \\
\text { maximize benefits to } \\
\text { participants? }\end{array}$ & $\begin{array}{l}\text { - Jang et al. (2016) received } \\
\text { approval from the Chungnam } \\
\text { National University Hospital } \\
\text { Institutional Review Board, } \\
\text { and waiver consents were } \\
\text { distributed to patients prior to } \\
\text { study. How the waivers were } \\
\text { delivered and how many were } \\
\text { received were not included in } \\
\text { the study. The retrospective } \\
\text { research is a safe way to } \\
\text { identify outcomes and make } \\
\text { appropriate connections } \\
\text { between anesthetics delivered } \\
\text { and patient outcomes }\end{array}$ \\
\hline Research design & $\begin{array}{l}\text { Was the most rigorous } \\
\text { design used, given the } \\
\text { study purpose? } \\
\text { Were appropriate } \\
\text { comparisons made to } \\
\text { enhance interpretability } \\
\text { of the findings? } \\
\text { Was the number of data } \\
\text { collection points } \\
\text { appropriate? } \\
\text { Did the design minimize } \\
\text { biases and threats to the } \\
\text { internal, construct, and } \\
\text { external validity of the } \\
\text { study (e.g., was blinding } \\
\text { used, was attrition } \\
\text { minimized)? }\end{array}$ & $\begin{array}{l}\text { A retrospective study was } \\
\text { appropriate for the study } \\
\text { purpose. } \\
\text { - Appropriate comparisons } \\
\text { were made between GA and } \\
\text { RA use. A consort flow chart } \\
\text { was used to clearly sort } \\
\text { patient selection. }\end{array}$ \\
\hline $\begin{array}{l}\text { Population and } \\
\text { sample }\end{array}$ & $\begin{array}{l}\text { Was the population } \\
\text { identified? Was the } \\
\text { sample described in } \\
\text { sufficient detail? }\end{array}$ & $\begin{array}{l}\text { Five hundred and thirty-one } \\
\text { total patients were reviewed, } \\
\text { final included in study ( } n= \\
\text { 137) patients for RA and ( } n\end{array}$ \\
\hline
\end{tabular}




\begin{tabular}{|c|c|c|}
\hline & $\begin{array}{l}\text { Was the best sampling } \\
\text { design used? } \\
\text { representativeness? } \\
\text { Were biases minimized? } \\
\text { Was the sample size } \\
\text { based on a power } \\
\text { analysis? }\end{array}$ & $\begin{array}{l}\text { =24) for GA after exclusion } \\
\text { criteria was evaluated. } \\
\text { - Inclusion criteria and } \\
\text { exclusion criteria were } \\
\text { included. }\end{array}$ \\
\hline $\begin{array}{l}\text { Data collection and } \\
\text { measurement }\end{array}$ & $\begin{array}{l}\text { Were the operational } \\
\text { and conceptual } \\
\text { definitions congruent? } \\
\text { Were key variables } \\
\text { measured using an } \\
\text { appropriate method } \\
\text { (e.g., interviews, } \\
\text { observations, and so } \\
\text { on)? } \\
\text { Were specific } \\
\text { instruments adequately } \\
\text { described and were they } \\
\text { good choices, given the } \\
\text { study population and the } \\
\text { variables being studied? } \\
\text { Did the report provide } \\
\text { evidence that the data } \\
\text { collection methods } \\
\text { yielded data that were } \\
\text { reliable, valid and } \\
\text { responsive? }\end{array}$ & $\begin{array}{l}\text { Data was collected and } \\
\text { reviewed by three residents } \\
\text { and the statistics were } \\
\text { conducted by specialists. } \\
\text { - } \\
\text { Data was collected to } \\
\text { determine if mortality due to } \\
\text { bladder cancer differed } \\
\text { between the patients who } \\
\text { underwent surgical } \\
\text { intervention and received } \\
\text { general anesthesia vs. regional } \\
\text { anesthesia. This study was } \\
\text { done to identify which } \\
\text { approach had better cancer } \\
\text { outcomes. } \\
\text { Conceptual and operational } \\
\text { definitions were clearly } \\
\text { defined and are congruent. } \\
\text { Demographic data was } \\
\text { collected and present in chart } \\
\text { formation. } \\
\text { Logistic regression analysis } \\
\text { for 5-year survival assessed } \\
\text { independent demographics to } \\
\text { find association. } \\
\text { Logistic regression was used } \\
\text { to identify any relation } \\
\text { between; BCG Treatments, } \\
\text { sex, smokers, hypertension, } \\
\text { diabetes, age, anesthesia type, } \\
\text { anesthesia time or length of } \\
\text { stay, and survival rates. } \\
\text { recurrence free time were } \\
\text { studied after the surgery using } \\
\text { Chi Squared test. } \\
\text { To evaluate Spearman }\end{array}$ \\
\hline
\end{tabular}




\begin{tabular}{|c|c|c|}
\hline & & $\begin{array}{l}\text { Rho correlation analysis was } \\
\text { used. }\end{array}$ \\
\hline Procedures & $\begin{array}{l}\text { If there was an } \\
\text { intervention, was it } \\
\text { adequately described, } \\
\text { and was it rigorously } \\
\text { developed and } \\
\text { implemented? Did most } \\
\text { participants allocated to } \\
\text { the intervention group } \\
\text { actually receive it? Was } \\
\text { there evidence of } \\
\text { intervention fidelity? } \\
\text { Were data collected in a } \\
\text { manner that minimized } \\
\text { bias? Were the staff } \\
\text { who collected data } \\
\text { appropriately trained? }\end{array}$ & $\begin{array}{l}\text { - Chart reviews were performed } \\
\text { at the Chungnam National } \\
\text { University Hospital. Data was } \\
\text { collected by three residents } \\
\text { and all statistical data was } \\
\text { processed by two independent } \\
\text { specialists. Numerous } \\
\text { analyses were undertaken to } \\
\text { evaluate the impact of } \\
\text { variables on the 5-year } \\
\text { survival rate and recurrence } \\
\text { free time. } \\
\text { All TURB surgeries were } \\
\text { performed by the same } \\
\text { surgical team and the same } \\
\text { anesthesia team. } \\
\text { Data was collected by three } \\
\text { different residents. } \\
\text { The statistics were reviewed } \\
\text { and processed independently } \\
\text { by two different specialists. }\end{array}$ \\
\hline Data Analysis & $\begin{array}{l}\text { Were analyses } \\
\text { undertaken to address } \\
\text { each research question } \\
\text { or test each hypothesis? } \\
\text { Were appropriate } \\
\text { statistical methods used, } \\
\text { given the level of } \\
\text { measurement of the } \\
\text { variables, number of } \\
\text { groups being compared, } \\
\text { and assumptions of the } \\
\text { texts? } \\
\text { Was a powerful analytic } \\
\text { method used? (e.g., did } \\
\text { the analysis help to } \\
\text { control for confounding } \\
\text { variables)? } \\
\text { Were type I and Type II } \\
\text { errors avoided or }\end{array}$ & $\begin{array}{l}\text { - Analyses were undertaken to } \\
\text { address the research question } \\
\text { and to test the hypothesis. } \\
\text { - Statistical methods were used } \\
\text { for the study. } \\
\text { The study included: } \\
\text { Kruskal-Wallis test was used } \\
\text { to help show normal } \\
\text { distribution between variables } \\
\text { (regional vs. general } \\
\text { anesthesia). } \\
\text { Chi-square test was also } \\
\text { incorporated to test observed } \\
\text { distribution of 5-year survival } \\
\text { between regional vs. general } \\
\text { technique. } \\
\text { Logistic regression analysis } \\
\text { was used to help identify } \\
\text { relationships among all the } \\
\text { variables (age, sex weight, } \\
\text { height, anesthesia time, }\end{array}$ \\
\hline
\end{tabular}




\begin{tabular}{|c|c|c|}
\hline & $\begin{array}{l}\text { minimized? } \\
\text { In intervention studies, } \\
\text { was an intention-to-treat } \\
\text { analysis performed? }\end{array}$ & $\begin{array}{l}\text { hospital stay, pathology stage, } \\
\text { BCG treatment, and medical } \\
\text { history including; diabetes, } \\
\text { hypertension, and smoking). } \\
\text { To evaluate age, Spearman } \\
\text { Rho correlation analysis was } \\
\text { used. } \\
\text { Multivariate correlation } \\
\text { analysis was used in the study } \\
\text { to analyze numerous variables } \\
\text { impacting recurrence free } \\
\text { time and 5-year survival rate. } \\
\text { Partial correlation analysis } \\
\text { was used to eliminate other } \\
\text { variables influence to identify } \\
\text { a relationship between only } 2 \\
\text { variables (regional vs. general } \\
\text { anesthesia) to find the true } \\
\text { factor influencing recurrence } \\
\text { free time and 5-year survival. } \\
\text { The data analysis section } \\
\text { lacked a thorough explanation } \\
\text { of the statistical analyses. } \\
\text { Evidence was shown, but not } \\
\text { explained very well for the } \\
\text { untrained audience. } \\
\text { by the researchers to describe } \\
\text { each data analysis method. } \\
\text { The data analysis section } \\
\text { lacked a thorough explanation } \\
\text { of the statistical analyses. }\end{array}$ \\
\hline $\begin{array}{l}\text { Data Analysis } \\
\text { (continued) }\end{array}$ & $\begin{array}{l}\text { Were problems of } \\
\text { missing values } \\
\text { evaluated and } \\
\text { adequately addressed? }\end{array}$ & $\begin{array}{l}\text { Missing values were not } \\
\text { evaluated or addressed in the } \\
\text { study. }\end{array}$ \\
\hline Findings & $\begin{array}{l}\text { Was information about } \\
\text { statistical significance } \\
\text { presented? Was } \\
\text { information about effect } \\
\text { size and precision of } \\
\text { estimates (confidence } \\
\text { intervals) presented? }\end{array}$ & $\begin{array}{l}\text { Demographic data was } \\
\text { collected and present in chart } \\
\text { formation. Logistic regression } \\
\text { analysis for 5-year survival } \\
\text { assessed independent } \\
\text { demographics to find } \\
\text { association. } \\
\text { - Findings were adequately }\end{array}$ \\
\hline
\end{tabular}




\begin{tabular}{|c|c|c|}
\hline & $\begin{array}{l}\text { Were the findings } \\
\text { adequately summarized, } \\
\text { with good use of tables } \\
\text { and figures? } \\
\text { Were findings reported } \\
\text { in a manner that } \\
\text { facilitates a meta- } \\
\text { analysis, and with } \\
\text { sufficient information } \\
\text { needed for EBP? }\end{array}$ & $\begin{array}{l}\text { summarized (Appendix B-6) } \\
\text { Evidence was provided, but } \\
\text { difficult for a reader not in the } \\
\text { field of anesthesia. } \\
\text { - Findings are not sufficient to } \\
\text { facilitate a metanalysis. }\end{array}$ \\
\hline $\begin{array}{l}\text { Discussion } \\
\text { Interpretation of the } \\
\text { findings }\end{array}$ & $\begin{array}{l}\text { Were all major findings } \\
\text { interpreted and } \\
\text { discussed within the } \\
\text { context of prior research } \\
\text { and/or the study's } \\
\text { conceptual framework? } \\
\text { Were casual inferences, } \\
\text { if any, justified? } \\
\text { Was the issue of clinical } \\
\text { significance discussed? } \\
\text { Were interpretations } \\
\text { well-founded and } \\
\text { consistent with the } \\
\text { study's limitations? } \\
\text { Did the report address } \\
\text { the issue of the } \\
\text { generalizability of the } \\
\text { findings? }\end{array}$ & $\begin{array}{l}\text { - A vague discussion of the } \\
\text { findings was included. The } \\
\text { discussion included } \\
\text { information that would have } \\
\text { been better suited for the } \\
\text { introduction section of this } \\
\text { research to grab a larger } \\
\text { audience's attention and to } \\
\text { provide a better understanding } \\
\text { of anesthetic impact on } \\
\text { cellular immunity and its } \\
\text { importance in surgical } \\
\text { interventions. As the } \\
\text { discussion continues, a } \\
\text { comparison of previous } \\
\text { studies results of regional } \\
\text { anesthesia and the effect on 5- } \\
\text { year survival and recurrence } \\
\text { free time in other types of } \\
\text { cancers is included. } \\
\text { Limitations were discussed, } \\
\text { and the authors stated they } \\
\text { could not easily conclude the } \\
\text { effects of anesthesia technique } \\
\text { on prognosis on bladder } \\
\text { cancer. The use of three } \\
\text { different analyses were } \\
\text { needed. Jang et al. (2013) } \\
\text { acknowledged the need for a } \\
\text { large sample size with random } \\
\text { experiments. } \\
\text { The report did not address } \\
\text { issue of generalizability. }\end{array}$ \\
\hline $\begin{array}{l}\text { Implications/ } \\
\text { recommendati- }\end{array}$ & $\begin{array}{l}\text { Did the researchers } \\
\text { discuss the implications }\end{array}$ & $\begin{array}{l}\text { - The need for further research } \\
\text { was discussed. }\end{array}$ \\
\hline
\end{tabular}




\begin{tabular}{|c|c|c|}
\hline ons & $\begin{array}{l}\text { of the study for clinical } \\
\text { practice or further } \\
\text { research-and were } \\
\text { those implications } \\
\text { reasonable and } \\
\text { complete? }\end{array}$ & \\
\hline $\begin{array}{l}\text { General Issues } \\
\text { Presentation }\end{array}$ & $\begin{array}{l}\text { Was the report well- } \\
\text { written, organized, and } \\
\text { sufficiently detailed for } \\
\text { critical analysis? } \\
\text { In intervention studies, } \\
\text { was a CONSORT } \\
\text { flowchart provided to } \\
\text { show the flow of } \\
\text { participants in the } \\
\text { study? }\end{array}$ & $\begin{array}{l}\text { Overall, the report was not as } \\
\text { organized as it could have } \\
\text { been. The use of numerous } \\
\text { analyses was needed to prove } \\
\text { a piece of the study. The use } \\
\text { of the consort flowchart } \\
\text { helped in the organization for } \\
\text { this study. }\end{array}$ \\
\hline $\begin{array}{l}\text { General Issues } \\
\text { Presentation } \\
\text { (continued) }\end{array}$ & $\begin{array}{l}\text { Was the report written } \\
\text { in a manner that makes } \\
\text { the findings accessible } \\
\text { to practicing nurses? }\end{array}$ & $\begin{array}{l}\text { This study needs to be } \\
\text { reorganized to be understood } \\
\text { by all professionals and not } \\
\text { just specific specialties. } \\
\text { Currently the study is written } \\
\text { only for the trained anesthesia } \\
\text { provider. }\end{array}$ \\
\hline Researcher credibility & $\begin{array}{l}\text { Do the researchers' } \\
\text { clinical, substantive, or } \\
\text { methodologic } \\
\text { qualifications and } \\
\text { experience enhance } \\
\text { confidence in the } \\
\text { findings and their } \\
\text { interpretation? }\end{array}$ & $\begin{array}{l}\text { The study was published in } \\
\text { the BMC Anesthesiology } \\
\text { Journal; however, } \\
\text { qualifications and experience } \\
\text { of authors were not included. }\end{array}$ \\
\hline Summary assessment & $\begin{array}{l}\text { Despite any limitations, } \\
\text { do the study findings } \\
\text { appear to be valid-do } \\
\text { you have confidence in } \\
\text { the truth value of the } \\
\text { results? } \\
\text { Does the study } \\
\text { contribute meaningful } \\
\text { evidence that can be } \\
\text { used in nursing } \\
\text { practice? }\end{array}$ & $\begin{array}{l}\text { The study does contribute } \\
\text { meaningful evidence, } \\
\text { however, the need for a larger } \\
\text { sample size with similar ages } \\
\text { and randomization are } \\
\text { recommended. This study } \\
\text { could be used as a guide for } \\
\text { future studies. }\end{array}$ \\
\hline
\end{tabular}

Note. $\mathrm{RA}=$ regional anesthesia; GA= general anesthesia 


\section{Appendix A-7}

Cho, Lee, Kim, Park, Park, Oh, Ho Lee, and Koo. (2017). The effects of perioperative anesthesia and analgesia on immune function in patients undergoing breast cancer resection: a prospective randomized study

\begin{tabular}{|c|c|c|}
\hline $\begin{array}{l}\text { Aspect of the } \\
\text { Report }\end{array}$ & Critiquing Questions & Detailed Critiquing Guidelines \\
\hline Title & $\begin{array}{l}\text { Is the title a good one, } \\
\text { succinctly suggesting key } \\
\text { variables and the study } \\
\text { population? }\end{array}$ & $\begin{array}{l}\text { - The title is } 16 \text { words in length and } \\
\text { clearly identifies the purpose of the } \\
\text { study. The title does not specify } \\
\text { what is being compared. }\end{array}$ \\
\hline Abstract & $\begin{array}{l}\text { Did the abstract clearly } \\
\text { and concisely summarize } \\
\text { the main features of the } \\
\text { report (problem, } \\
\text { methods, results, } \\
\text { conclusions)? }\end{array}$ & $\begin{array}{l}\text { - The abstract is clearly written with a } \\
\text { concise summary of the report. } \\
\text { Subheadings are included; } \\
\text { Introduction, methods, results, and } \\
\text { conclusion. } \\
\text { - The introduction provides the reader } \\
\text { with an explanation of the impact of } \\
\text { anesthesia on the immune system. It } \\
\text { identifies the important role the } \\
\text { Natural Killer (NK) cells play in } \\
\text { anti-tumor immunity. The intro } \\
\text { further identifies what is being } \\
\text { compared in the study; effects of } \\
\text { two different anesthesia and } \\
\text { analgesia methods on NK cell } \\
\text { cytotoxicity (NKCC) in patient } \\
\text { undergoing breast cancer surgery. }\end{array}$ \\
\hline $\begin{array}{l}\text { Introduction } \\
\text { Statement of } \\
\text { the problem }\end{array}$ & $\begin{array}{l}\text { Was the problem stated } \\
\text { unambiguously, and was } \\
\text { it easy to identify? } \\
\text { Is the problem statement } \\
\text { build a persuasive } \\
\text { argument for the new } \\
\text { study? } \\
\text { Was there a good match } \\
\text { between the research } \\
\text { problem and the methods } \\
\text { used -that is, was a } \\
\text { quantitative approach } \\
\text { appropriate? }\end{array}$ & $\begin{array}{l}\text { - Cho et al. (2017) identify the impact } \\
\text { of anesthesia and surgical stress on } \\
\text { anti-tumor defenses within the body. } \\
\text { Authors clearly identify the problem } \\
\text { of anesthesia on NKC function. } \\
\text { - Prior prospective studies comparing } \\
\text { the effects of anesthetics } \\
\text { perioperative use on NKCC in } \\
\text { cancer patients undergoing surgical } \\
\text { intervention have been } \\
\text { acknowledged. } \\
\text { Previous studies have identified the } \\
\text { use of volatile anesthetics as } \\
\text { decreasing NKCC. Opioids have } \\
\text { shown suppression of NKC } \\
\text { function. The use of Propofol did } \\
\text { not suppress NKCC and non- } \\
\text { steroidal anti-inflammatory drugs }\end{array}$ \\
\hline
\end{tabular}




\begin{tabular}{|c|c|c|}
\hline & & $\begin{array}{l}\text { have not shown evidence of NKC } \\
\text { suppression (Cho et al., 2017). } \\
\text { - A quantitative approach was used } \\
\text { for this study. }\end{array}$ \\
\hline $\begin{array}{l}\text { Hypotheses or } \\
\text { research } \\
\text { questions }\end{array}$ & $\begin{array}{l}\text { Were research questions } \\
\text { and/or hypotheses } \\
\text { explicitly stated? If not, } \\
\text { was their absence } \\
\text { justified? } \\
\text { Were questions and } \\
\text { hypotheses appropriately } \\
\text { worded, with clear } \\
\text { specification of key } \\
\text { variables and the study } \\
\text { population? } \\
\text { Were the } \\
\text { questions/hypotheses } \\
\text { consistent with existing } \\
\text { knowledge? }\end{array}$ & $\begin{array}{l}\text { - Researchers hypothesized that } \\
\text { avoiding volatile anesthetics and } \\
\text { opioid analgesics might attenuate } \\
\text { immunosuppressive effects during } \\
\text { perioperative periods. } \\
\text { - The hypothesis was consistent with } \\
\text { prior knowledge, included in study } \\
\text { by researchers. }\end{array}$ \\
\hline $\begin{array}{l}\text { Literature } \\
\text { review }\end{array}$ & $\begin{array}{l}\text { Was the literature review } \\
\text { up-to-date and based } \\
\text { mainly on primary } \\
\text { sources? } \\
\text { Did the review provide a } \\
\text { state-of-the-art synthesis } \\
\text { of evidence on the } \\
\text { problem? } \\
\text { Did the literature review } \\
\text { provide a strong basis for } \\
\text { the new study? }\end{array}$ & $\begin{array}{l}\text { - A literature review was based on } \\
\text { primary sources from 2003-2015. } \\
\text { The literature included a review on } \\
\text { the evidence of the problem, which } \\
\text { could have been more in-depth with } \\
\text { a deeper impact of the importance of } \\
\text { the problem. } \\
\text { The literature did not provide a } \\
\text { strong basis for the new study. A } \\
\text { more detailed literature review is } \\
\text { recommended. }\end{array}$ \\
\hline $\begin{array}{l}\text { Conceptual/ } \\
\text { theoretical } \\
\text { framework }\end{array}$ & $\begin{array}{l}\text { Were key concepts } \\
\text { adequately defined } \\
\text { conceptually? } \\
\text { Was a conceptual } \\
\text { theoretical framework } \\
\text { articulated—and, if so, } \\
\text { was it appropriate? Is } \\
\text { the absence of a } \\
\text { framework justified? } \\
\text { Were the } \\
\text { questions/hypotheses }\end{array}$ & $\begin{array}{l}\text { - Key concepts were addressed, and } \\
\text { brief conceptual definitions were not } \\
\text { included for all concepts. } \\
\text { - No framework was articulated in } \\
\text { this study. }\end{array}$ \\
\hline
\end{tabular}




\begin{tabular}{|c|c|c|}
\hline & $\begin{array}{l}\text { consistent with the } \\
\text { framework? }\end{array}$ & \\
\hline $\begin{array}{l}\text { Method } \\
\text { Protection of } \\
\text { human rights }\end{array}$ & $\begin{array}{l}\text { Were appropriate } \\
\text { procedures used to safe- } \\
\text { guard the rights of study } \\
\text { participants? } \\
\text { Was the study externally } \\
\text { reviewed by an } \\
\text { IRB/ethics review board? } \\
\text { Was the study designed } \\
\text { to minimize risks and } \\
\text { maximize benefits to } \\
\text { participants? }\end{array}$ & $\begin{array}{l}\text { - Approval was obtained by the } \\
\text { Institutional Review Board and } \\
\text { Hospital Research Ethics Committee } \\
\text { of Severance Hospital, Yonsei } \\
\text { University Health System, Seoul, } \\
\text { Korea, on February 2014. It was } \\
\text { registered at clinicaltrial.gov on } \\
\text { March } 2014 \text {. } \\
\text { - Written informed consent was } \\
\text { obtained from all patients } \\
\text { Fifty patients were randomly } \\
\text { assigned into one of the study } \\
\text { groups (25 patients each) using a } \\
\text { computer-generated random number } \\
\text { table. }\end{array}$ \\
\hline $\begin{array}{l}\text { Research } \\
\text { design }\end{array}$ & $\begin{array}{l}\text { Was the most rigorous } \\
\text { design used, given the } \\
\text { study purpose? } \\
\text { Were appropriate } \\
\text { comparisons made to } \\
\text { enhance interpretability } \\
\text { of the findings? } \\
\text { Was the number of data } \\
\text { collection points } \\
\text { appropriate? } \\
\text { Did the design minimize } \\
\text { biases and threats to the } \\
\text { internal, construct, and } \\
\text { external validity of the } \\
\text { study (e.g., was blinding } \\
\text { used, was attrition } \\
\text { minimized)? }\end{array}$ & $\begin{array}{l}\text { - An experimental randomized control } \\
\text { study was utilized for this study. } \\
\text { Appropriate comparisons were } \\
\text { made, using other research for } \\
\text { support and credibility. The number } \\
\text { of data points were appropriate, } \\
\text { including natural killer cell } \\
\text { cytotoxicity, serum concentration } \\
\text { levels of IL-2, inflammatory } \\
\text { response, pain score, and } \\
\text { postoperative outcomes. } \\
\text { The design did minimize biases and } \\
\text { threats to internal and external } \\
\text { validity. Blinding was used } \\
\text { however, staff in operating room } \\
\text { were aware of which technique was } \\
\text { utilized for each patient. Attrition } \\
\text { was factored in as a } 10 \% \text { dropout } \\
\text { rate. Attrition was not an issue. }\end{array}$ \\
\hline $\begin{array}{l}\text { Population and } \\
\text { sample }\end{array}$ & $\begin{array}{l}\text { Was the population } \\
\text { identified? Was the } \\
\text { sample described in } \\
\text { sufficient detail? } \\
\text { Was the best possible } \\
\text { sampling design used to } \\
\text { enhance the sample's } \\
\text { representativeness? }\end{array}$ & $\begin{array}{l}\text { The population was identified as } \\
\text { breast cancer patients, 20-65 years } \\
\text { old who underwent elective surgery } \\
\text { for breast cancer and had an } \\
\text { American Society of } \\
\text { Anesthesiologists (ASA) physical } \\
\text { status classification of I to III. } \\
\text { - The exclusion criteria were patients } \\
\text { with renal or hepatic impairment, a }\end{array}$ \\
\hline
\end{tabular}




\begin{tabular}{|c|c|c|}
\hline & $\begin{array}{l}\text { Were sampling biases } \\
\text { minimized? } \\
\text { Was the sample size } \\
\text { based on a power } \\
\text { analysis? }\end{array}$ & $\begin{array}{l}\text { body mass index }>35 \mathrm{~kg} / \mathrm{m} 2 \text {, } \\
\text { immunosuppressive therapy, } \\
\text { immune disorders, steroid } \\
\text { administration within the last six } \\
\text { months, metastasis, or radiotherapy } \\
\text { or chemotherapy before surgery. } \\
\text { Written formed consent was } \\
\text { obtained from all of patients. } \\
\text { The sample was small } \\
\text { The same was based on a power } \\
\text { analysis. The sample size was } \\
\text { calculated based on preliminary } \\
\text { results for the first five patients of } \\
\text { each group and estimated that } 22 \\
\text { patients in each group would be } \\
\text { required to detect a mean difference } \\
\text { of } 10 \% \text { and standard deviation of } \\
10 \% \text { in the NKCC after surgery with } \\
90 \% \text { power at a significance of ( } p< \\
0.05 \text { ). } \\
\text { Twenty-Five patients were enrolled } \\
\text { to factor in for a } 10 \% \text { dropout rate. }\end{array}$ \\
\hline $\begin{array}{l}\text { Data collection } \\
\text { and } \\
\text { measurement }\end{array}$ & $\begin{array}{l}\text { Were the operational and } \\
\text { conceptual definitions } \\
\text { congruent? } \\
\text { Were key variables } \\
\text { measured using an } \\
\text { appropriate method (e.g., } \\
\text { interviews, observations, } \\
\text { and so on)? } \\
\text { Were specific } \\
\text { instruments adequately } \\
\text { described and were they } \\
\text { good choices, given the } \\
\text { study population and the } \\
\text { variables being studied? } \\
\text { Did the report provide } \\
\text { evidence that the data } \\
\text { collection methods } \\
\text { yielded data that were } \\
\text { reliable, valid and } \\
\text { responsive? }\end{array}$ & $\begin{array}{l}\text { - Operation and conceptual } \\
\text { definitions for the study appear } \\
\text { congruent. } \\
\text { Key variable measures were } \\
\text { completed by observations and } \\
\text { interviews. } \\
\text { The primary aim was to compare the } \\
\text { effects of two anesthetic and } \\
\text { analgesic methods on the immune } \\
\text { function assessed by NKCC, } \\
\text { measured preoperatively and at } 24 \\
\text { hours postoperatively. Other } \\
\text { outcome measures included } \\
\text { postoperative pain scores, IL-2 } \\
\text { levels, and inflammatory responses } \\
\text { assessed by white blood cell, } \\
\text { neutrophil, and lymphocyte counts. } \\
\text { The incidence of cancer recurrence } \\
\text { or metastasis was evaluated with a } \\
\text { breast ultrasound, abdomen } \\
\text { ultrasound, and whole-body bone } \\
\text { scan every } 6 \text { months after surgery. }\end{array}$ \\
\hline Procedures & If there was an & - Interventions were adequately \\
\hline
\end{tabular}




\begin{tabular}{|c|c|c|}
\hline & $\begin{array}{l}\text { intervention, was it } \\
\text { adequately described, and } \\
\text { was it rigorously } \\
\text { developed and } \\
\text { implemented? Did most } \\
\text { participants allocated to } \\
\text { the intervention group } \\
\text { actually receive it? Was } \\
\text { there evidence of } \\
\text { intervention fidelity? } \\
\text { Were data collected in a } \\
\text { manner that minimized } \\
\text { bias? Were the staff who } \\
\text { collected data } \\
\text { appropriately trained? }\end{array}$ & $\begin{array}{l}\text { described. } \\
\text { Data was collected in a manner that } \\
\text { minimized bias. } \\
\text { Data collected included: } \\
\text { - Assay for natural killer cell } \\
\text { cytotoxicity: Blood samples were } \\
\text { obtained before and at } 24 \text { hours after } \\
\text { surgery. A colorimetric assay was } \\
\text { used and measured lactate } \\
\text { dehydrogenase (LDH), a stable } \\
\text { cytosolic enzyme that is released } \\
\text { upon cell lysis. } \\
\text { Assay for IL-2: IL-2 was measured } \\
\text { in serum using an ELISA kit } \\
\text { preoperatively and at } 24 \text { hours after } \\
\text { surgery. } \\
\text { Pain scores were assessed using an } \\
\text { 11-point numerical scale at } \\
\text { postoperative intervals: } 30 \text { minutes, } \\
6 \text { hours, } 24 \text { hours, and } 48 \text { hours. } \\
\text { For immediate postoperative } \\
\text { analgesia, the P-R-K group received } \\
\text { ketorolac } 60 \text { mg and the S-R-F } \\
\text { group received fentanyl } 50 \mu \text { g at the } \\
\text { end of surgery. } \\
\text { In the post-anesthesia care unit, } \\
\text { propacetamol } 2 \text { g in the P-R-K } \\
\text { group or fentanyl } 50 \mu \text { g in the S-R-F } \\
\text { group was available as an additional } \\
\text { analgesic for patients with an NRS } \geq \\
\text { appropriately trained in research. } \\
\text { tramadol } 50 \text { mg as a rescue } \\
\text { analgesic, which does not suppress } \\
\text { NKCC. }\end{array}$ \\
\hline Data Analysis & $\begin{array}{l}\text { Were analyses } \\
\text { undertaken to address } \\
\text { each research question or } \\
\text { test each hypothesis? } \\
\text { Were appropriate } \\
\text { statistical methods used, } \\
\text { given the level of } \\
\text { measurement of the } \\
\text { variables, number of }\end{array}$ & $\begin{array}{l}\text { - Statistical analyses were performed } \\
\text { with IBM SPSS } 20.0 \text { and SAS } 9.2 \\
\text { Continuous variables were analyzed } \\
\text { with the independent t-test or Mann- } \\
\text { Whitney U test, after testing for } \\
\text { normality of distribution using } \\
\text { Kolmogorov-Smirnov test. } \\
\text { - Categorical variables were analyzed } \\
\text { with } \chi 2 \text { test or Fisher exact test. } \\
\text { - Variables measured were analyzed }\end{array}$ \\
\hline
\end{tabular}




\begin{tabular}{|c|c|c|}
\hline & $\begin{array}{l}\text { groups being compared, } \\
\text { and assumptions of the } \\
\text { texts? } \\
\text { Was a powerful analytic } \\
\text { method used? } \\
\text { Were type I and Type II } \\
\text { errors avoided or } \\
\text { minimized? } \\
\text { In intervention studies, } \\
\text { was an intention-to-treat } \\
\text { analysis performed? }\end{array}$ & $\begin{array}{l}\text { with a linear mixed model, with } \\
\text { patient indicator as a random effect } \\
\text { and with group, time, and group-by- } \\
\text { time as fixed effects. The group-by- } \\
\text { time interaction assesses whether } \\
\text { the change over time differs } \\
\text { between groups. Post-hoc analyses } \\
\text { with the Bonferroni correction were } \\
\text { performed for comparisons when } \\
\text { variables with repeated measures } \\
\text { showed significant differences } \\
\text { between groups. Statistically } \\
\text { significance was ( } p<0.05 \text { ). } \\
\text { Type I errors were minimized by } \\
\text { having significance of ( } p<0.05 \text { ), } \\
\text { reducing the probability of a type I } \\
\text { error. } \\
\text { A larger sample size should be used } \\
\text { to avoid or minimize type II errors. }\end{array}$ \\
\hline $\begin{array}{l}\text { Data Analysis } \\
\text { (continued) }\end{array}$ & $\begin{array}{l}\text { Were problems of } \\
\text { missing values evaluated } \\
\text { and adequately } \\
\text { addressed? }\end{array}$ & $\begin{array}{l}\text { Of } 50 \text { patients enrolled, one patient } \\
\text { in each group was eliminated due to } \\
\text { concurrent breast reconstruction } \\
\text { surgery. The remaining } 48 \text { patients } \\
\text { completed the study without any } \\
\text { complications. }\end{array}$ \\
\hline Findings & $\begin{array}{l}\text { Was information about } \\
\text { statistical significance } \\
\text { presented? Was } \\
\text { information about effect } \\
\text { size and precision of } \\
\text { estimates (confidence } \\
\text { intervals) presented? } \\
\text { Were the findings } \\
\text { adequately summarized, } \\
\text { with good use of tables } \\
\text { and figures? } \\
\text { Were findings reported in } \\
\text { a manner that facilitates a } \\
\text { meta-analysis, and with } \\
\text { sufficient information } \\
\text { needed for EBP? }\end{array}$ & $\begin{array}{l}\text { - Information about statistical } \\
\text { significance was presented including } \\
\text { confidence intervals. } \\
\text { - Findings were summarized in both } \\
\text { tables and figures. } \\
\text { - Findings were reported in a manner } \\
\text { to facilitate a meta-analysis. }\end{array}$ \\
\hline $\begin{array}{l}\text { Discussion } \\
\text { Interpretation } \\
\text { of the findings }\end{array}$ & $\begin{array}{l}\text { Were all major findings } \\
\text { interpreted and discussed } \\
\text { within the context of }\end{array}$ & $\begin{array}{l}\text { Major findings were included and } \\
\text { discussed within the context of prior } \\
\text { research. }\end{array}$ \\
\hline
\end{tabular}




\begin{tabular}{|c|c|c|}
\hline & $\begin{array}{l}\text { prior research and/or the } \\
\text { study's conceptual } \\
\text { framework? } \\
\text { Were casual inferences, } \\
\text { if any, justified? } \\
\text { Was the issue of clinical } \\
\text { significance discussed? } \\
\text { Were interpretations } \\
\text { well-founded and } \\
\text { consistent with the } \\
\text { study's limitations? } \\
\text { Did the report address the } \\
\text { issue of the } \\
\text { generalizability of the } \\
\text { findings? }\end{array}$ & $\begin{array}{l}\text { - } \quad \text { Clinical significance was discussed. } \\
\text { Patients who received P-K } \\
\text { anesthesia exhibited preserved } \\
\text { NKCC compared to pts who } \\
\text { received S-F anesthesia. } \\
\text { - } \text { Postoperative inflammatory } \\
\text { responses and the incidences of } \\
\text { short-term cancer recurrence and } \\
\text { metastasis were not different } \\
\text { between the two anesthetic and } \\
\text { analgesic methods. } \\
\text { Evidence suggests that surgery and } \\
\text { anesthesia cause a brief period of } \\
\text { immunosuppression, which may } \\
\text { encourage both the implantation of } \\
\text { surgically disseminated neoplastic } \\
\text { cells and the growth of existing } \\
\text { micro-metastases. } \\
\text { Limits included non-blinded } \\
\text { operating staff to the group } \\
\text { allocation, however follow-up staff } \\
\text { was unaware of patient group } \\
\text { involvement when assessing for } \\
\text { pain. } \\
\text {-The use of Remifentanil and } \\
\text { tramadol for a control was used, and } \\
\text { their impact on NKCC cannot be } \\
\text { excluded. } \\
\text { discussed. }\end{array}$ \\
\hline $\begin{array}{l}\text { Implications/ } \\
\text { recommendati- } \\
\text { ons }\end{array}$ & $\begin{array}{l}\text { Did the researchers } \\
\text { discuss the implications } \\
\text { of the study for clinical } \\
\text { practice or further } \\
\text { research-and were those } \\
\text { implications reasonable } \\
\text { and complete? }\end{array}$ & $\begin{array}{l}\text { Researchers discuss the implications } \\
\text { of the study for future research. } \\
\text { Researchers acknowledged that } \\
\text { cancer metastasis within two years } \\
\text { after surgery did not occur in the } \\
\text { study, further evaluation of long- } \\
\text { term outcomes are needed to make } \\
\text { further conclusions about cancer } \\
\text { recurrence or metastasis. }\end{array}$ \\
\hline $\begin{array}{l}\text { General } \\
\text { Issues } \\
\text { Presentation }\end{array}$ & $\begin{array}{l}\text { Was the report well- } \\
\text { written, organized, and } \\
\text { sufficiently detailed for } \\
\text { critical analysis? } \\
\text { Was a CONSORT } \\
\text { flowchart provided? }\end{array}$ & $\begin{array}{l}\text { - The report was well written and } \\
\text { organized. The literature review } \\
\text { could have used more information to } \\
\text { educate the reader on the importance } \\
\text { and impact of the immune system. A } \\
\text { longer, more detailed study is }\end{array}$ \\
\hline
\end{tabular}




\begin{tabular}{|c|c|c|}
\hline & & $\begin{array}{l}\text { recommended. } \\
\text { - A consort flowchart was not } \\
\text { provided. }\end{array}$ \\
\hline $\begin{array}{l}\text { General } \\
\text { Issues } \\
\text { Presentation } \\
\text { (continued) }\end{array}$ & $\begin{array}{l}\text { Was the report written in } \\
\text { a manner that makes the } \\
\text { findings accessible to } \\
\text { practicing nurses? }\end{array}$ & $\begin{array}{l}\text { - The report was written in a manner } \\
\text { that makes the findings accessible to } \\
\text { practicing nurses. The journal is a } \\
\text { part of the international journal of } \\
\text { medical sciences and is an open } \\
\text { article available to all. Good } \\
\text { background support provides a } \\
\text { strong confidence in the benefit of } \\
\text { Propofol and Ketorolac's use in the } \\
\text { cancer patient to decrease immune } \\
\text { suppression. }\end{array}$ \\
\hline $\begin{array}{l}\text { Researcher } \\
\text { credibility }\end{array}$ & $\begin{array}{l}\text { Do the researchers' } \\
\text { clinical, substantive, or } \\
\text { methodologic } \\
\text { qualifications and } \\
\text { experience enhance } \\
\text { confidence in the } \\
\text { findings and their } \\
\text { interpretation? }\end{array}$ & $\begin{array}{l}\text { Researchers qualifications/experience are as } \\
\text { follows: } \\
\text { - Department of Anesthesiology and } \\
\text { Pain Medicine, Anesthesia and Pain } \\
\text { Research Institute, Yonsei } \\
\text { University College of Medicine, } \\
\text { Seoul, Republic of Korea } \\
\text { - National Leading Research } \\
\text { Laboratory of Clinical } \\
\text { Nutrigenetics/Nutrigenomics, } \\
\text { Department of Food and Nutrition, } \\
\text { College of Human Ecology, Yonsei } \\
\text { University, Seoul, Republic of } \\
\text { Korea } \\
\text { Korea Ginseng Corporation } \\
\text { Research Institute, Korea Ginseng } \\
\text { Corporation, Daejeon, Republic of } \\
\text { Korea } \\
\text { Department of Surgery, Yonsei } \\
\text { University College of Medicine, } \\
\text { Seoul, Republic of Korea. } \\
\text { Department of Food and Nutrition, } \\
\text { Brain Korea 21 PLUS Project, } \\
\text { College of Human Ecology, Yonsei } \\
\text { University, Seoul, Republic of } \\
\text { Korea } \\
\text { Research Center for Silver Science, } \\
\text { Institute of Symbiotic Life-TECH, } \\
\text { Yonsei University, Seoul, Republic } \\
\text { of Korea. } \\
\text { confidence in the finds and } \\
\text { - } \\
\text { - } \\
\text { - }\end{array}$ \\
\hline
\end{tabular}




\begin{tabular}{|l|l|l|}
\hline $\begin{array}{l}\text { Summary } \\
\text { assessment }\end{array}$ & $\begin{array}{l}\text { Do the study findings } \\
\text { appear to be valid: do } \\
\text { you have confidence in } \\
\text { the truth value of the } \\
\text { results? }\end{array}$ & $\begin{array}{l}\text { interpretations of this study. } \\
\text { The findings of the present study are } \\
\text { consistent with the hypothesis that } \\
\text { avoiding volatile anesthetics and } \\
\text { opioids could reduce the } \\
\text { immunosuppression during surgery. } \\
\text { can be used in nursing } \\
\text { practice. }\end{array}$ \\
& $\begin{array}{l}\text { All supportive literature was } \\
\text { appropriately cited and congruent } \\
\text { with this study's findings. }\end{array}$ \\
& $\begin{array}{l}\text { Further studies to find anesthetic and } \\
\text { analgesic methods which mitigate } \\
\text { immunosuppression in cancer surgery are } \\
\text { warranted. }\end{array}$ \\
\hline
\end{tabular}

Note: $\mathrm{NK}=$ natural killer cell; $\mathrm{NKCC}=$ natural killer cell cytotoxicity; P-R-K= propofol, remifentanil, ketorolac; S-R-F= sevoflurane, remifentanil, fentanyl; IL= interleukin 


\section{Appendix A-8}

Perez-Gonzalez, Cuellar-Guzman, Soliz, and Cata. (2017). Impact of reginal anesthesia on recurrence, metastasis, and immune response in breast cancer surgery: a systematic review of the literature.

\begin{tabular}{|c|c|c|}
\hline $\begin{array}{l}\text { Aspect of the } \\
\text { Report }\end{array}$ & Critiquing Questions & Detailed Critiquing Guidelines \\
\hline Title & $\begin{array}{l}\text { Is the title a good one, } \\
\text { succinctly suggesting } \\
\text { key variables and the } \\
\text { study population? }\end{array}$ & $\begin{array}{l}\text { The title identified breast cancer } \\
\text { patients as the population of interest } \\
\text { and the key variables; regional } \\
\text { anesthesia use, and the effects of } \\
\text { cancer recurrence, } \\
\text { immunomodulation and survival rate. }\end{array}$ \\
\hline Abstract & $\begin{array}{l}\text { Did the abstract clearly } \\
\text { and concisely } \\
\text { summarize the main } \\
\text { features of the report } \\
\text { (problem, methods, } \\
\text { results, conclusions)? }\end{array}$ & $\begin{array}{l}\text { - The abstract identified the } \\
\text { perioperative period as an important } \\
\text { time for long-term outcomes for } \\
\text { breast cancer. Methods include a } \\
\text { systematic literature search for breast } \\
\text { cancer surgeries conducted with the } \\
\text { use of a paravertebral regional block } \\
\text { (PVB) anesthetic. The use of both } \\
\text { retrospective studies and randomized } \\
\text { control trials were included. } \\
\text { The results identified } 467 \text { studies, } 15 \\
\text { studies were included and underwent } \\
\text { full review. The conclusions included } \\
\text { a lack of substantial data regarding } \\
\text { the use of PVB in cancer recurrence } \\
\text { reduction rates. } \\
\text { The review did identify a relation } \\
\text { between PVB and decreased levels of } \\
\text { inflammation and improved immune } \\
\text { response compared to general } \\
\text { anesthesia and opioid-based } \\
\text { analgesia. }\end{array}$ \\
\hline $\begin{array}{l}\text { Introduction } \\
\text { Statement of } \\
\text { the problem }\end{array}$ & $\begin{array}{l}\text { Were authors' } \\
\text { affiliations provided? } \\
\text { Did the review have } \\
\text { support of at least } 2 \\
\text { authors? } \\
\text { Was the study objective } \\
\text { \& rationale given? } \\
\text { Terms defined? } \\
\text { Was there enough }\end{array}$ & $\begin{array}{l}\text { - The author's affiliations were not } \\
\text { provided. } \\
\text { The study was objective and provided } \\
\text { adequate rationale for the review. The } \\
\text { authors use statistics to support the } \\
\text { purpose. Peres-Gonzales et al. (2017) } \\
\text { identify breast cancer as the second } \\
\text { most common cancer and the } 5^{\text {th }} \\
\text { cause of death related to cancer with } \\
\text { 30\%-40\% of these patients dying due } \\
\text { to metastatic spread of the disease. }\end{array}$ \\
\hline
\end{tabular}




\begin{tabular}{|c|c|c|}
\hline & $\begin{array}{l}\text { information on the } \\
\text { population studied, the } \\
\text { intervention given, and } \\
\text { the outcomes considered }\end{array}$ & $\begin{array}{l}\text { The authors identify surgical } \\
\text { intervention as the primary treatment. } \\
\text { The authors identified the aim to } \\
\text { assess the impact that regional } \\
\text { anesthesia, on metastasis, } \\
\text { inflammation, immunosuppression } \\
\text { during breast cancer surgery, and } \\
\text { recurrence of cancer after surgical } \\
\text { intervention. }\end{array}$ \\
\hline $\begin{array}{l}\text { Hypotheses } \\
\text { or research } \\
\text { questions }\end{array}$ & $\begin{array}{l}\text { Is the main question or } \\
\text { problem clear and } \\
\text { focused? PICO format } \\
\text { used? }\end{array}$ & $\begin{array}{l}\text { The hypothesis was clear and focused } \\
\text { with the use of PICO: the use of a } \\
\text { regional anesthesia technique could } \\
\text { be associated with better long-term } \\
\text { outcomes after breast cancer surgical } \\
\text { intervention. The audience was able } \\
\text { to clearly identify the population, } \\
\text { intervention and outcome. The } \\
\text { comparison was not identified but } \\
\text { discussed in different parts of the } \\
\text { review. }\end{array}$ \\
\hline $\begin{array}{l}\text { Literature } \\
\text { Review }\end{array}$ & $\begin{array}{l}\text { Was the literature review } \\
\text { up-to-date and based } \\
\text { mainly on primary } \\
\text { sources? } \\
\text { Did the review provide a } \\
\text { state-of-the-art synthesis } \\
\text { of evidence on the } \\
\text { problem? } \\
\text { Did the literature review } \\
\text { provide a strong basis } \\
\text { for the review? }\end{array}$ & $\begin{array}{l}\text { - The literature review was up-to-date } \\
\text { including primary sources from 2005- } \\
\text { 2017. The review provided a clear } \\
\text { understanding of the problem. Breast } \\
\text { cancer was identified as the second } \\
\text { most common cancers and identify } \\
\text { metastatic recurrence as the primary } \\
\text { cause of breast cancer related deaths. } \\
\text { The literature provided the reader } \\
\text { with an understanding of the primary } \\
\text { therapy being surgical intervention } \\
\text { for this population. Evidence was } \\
\text { provided from primary sources of the } \\
\text { association with surgical trauma and } \\
\text { cell proliferation. Anesthetic drugs, } \\
\text { anesthesia technique and opioid use } \\
\text { were also included as having } \\
\text { involvement in the metastatic } \\
\text { process. }\end{array}$ \\
\hline $\begin{array}{l}\text { Search } \\
\text { Criteria } \\
\text { Methods }\end{array}$ & $\begin{array}{l}\text { Please describe the } \\
\text { search criteria the } \\
\text { authors used. } \\
\text { Inclusion / exclusion } \\
\text { criteria listed. Was there } \\
\text { enough information on }\end{array}$ & $\begin{array}{l}\text { The systematic literature included } \\
\text { search portals: PubMed, } \\
\text { EMBASE,MEDLINE, the Cochrane } \\
\text { Trials Register, and Web of Science } \\
\text { databases. The search was conducted } \\
\text { by all authors from inception through } \\
\text { December 2017. Methods of the }\end{array}$ \\
\hline
\end{tabular}




\begin{tabular}{|c|c|c|}
\hline & $\begin{array}{l}\text { the population studied, } \\
\text { the intervention given } \\
\text { and the outcomes } \\
\text { considered? } \\
\text { Comprehensive, } \\
\text { systematic search used? } \\
\text { Explicit criteria listed? } \\
\text { Search terms and } \\
\text { databases used? grey } \\
\text { literature discussion? } \\
\text { Is it likely that all } \\
\text { relevant studies } \\
\text { (published and } \\
\text { unpublished) were } \\
\text { identified? }\end{array}$ & $\begin{array}{l}\text { Cochrane Collaboration and the } \\
\text { Preferred Reporting Items for } \\
\text { Systematic Reviews and Meta- } \\
\text { analyses statement were used for } \\
\text { strategy. Searched terms included } \\
\text { Breast Cancer, Anesthetic Technique, } \\
\text { Anesthesia, Epidural Anesthesia, } \\
\text { Regional Anesthesia, Disease Free } \\
\text { Survival, Progression Free Survival, } \\
\text { Recurrence and Metastasis. Filters } \\
\text { were added, including Randomized } \\
\text { Controlled Trials (RCT), Controlled } \\
\text { Trials, and Human. Bibliographies of } \\
\text { retrieved studies were also examined. } \\
\text { Added to the search were survival } \\
\text { and metastasis-related, to avoid } \\
\text { missed studies. } \\
\text { Inclusion criteria included; RCT, } \\
\text { observational cohort studies } \\
\text { published in English, adult patients, } \\
\text { patients undergoing breast cancer } \\
\text { surgery, regional anesthesia } \\
\text { technique for BC surgery, effects of } \\
\text { regional anesthesia or analgesia on } \\
\text { post op outcomes, inflammatory } \\
\text { process and immune function, cancer } \\
\text { recurrence rates, disease free } \\
\text { survival. Exclusion criteria included; } \\
\text { in vitro and animal studies, case } \\
\text { reports. } \\
\text { Four hundred and sixty-seven } \\
\text { relevant studies were located, } 121 \\
\text { underwent abstract review, 107 } \\
\text { excluded for not meeting inclusion } \\
\text { criteria, } 15 \text { studies were included. } \\
\text { the } \text {. }\end{array}$ \\
\hline Framework & $\begin{array}{l}\text { Did authors use a model } \\
\text { or guideline for SRs and } \\
\text { inclusive of the model } \\
\text { they used? }\end{array}$ & $\begin{array}{l}\text { The Preferred Reporting Items for } \\
\text { Systematic Reviews and Meta- } \\
\text { analyses (PRISMA) was used to } \\
\text { complete this review. }\end{array}$ \\
\hline $\begin{array}{l}\text { Included } \\
\text { studies of the } \\
\text { Systematic } \\
\text { Review }\end{array}$ & $\begin{array}{l}\text { Was sufficient } \\
\text { information given on } \\
\text { chosen studies to } \\
\text { determine validity of the } \\
\text { research? }\end{array}$ & $\begin{array}{l}\text { - Two authors independently reviewed } \\
\text { titles and abstracts for inclusion to } \\
\text { this review. Any disagreements were } \\
\text { settled by a third author. } \\
\text { - The Newcastle-Ottawa scale was }\end{array}$ \\
\hline
\end{tabular}




\begin{tabular}{|c|c|c|}
\hline & $\begin{array}{l}\text { Were PICO and } \\
\text { methodological quality } \\
\text { of each study addressed } \\
\text { in table format? Did the } \\
\text { authors critically } \\
\text { appraise each study? } \\
\text { Were the criteria used to } \\
\text { select articles for } \\
\text { inclusion predetermined, } \\
\text { clearly stated, and } \\
\text { appropriate? }\end{array}$ & $\begin{array}{l}\text { utilized to grade the quality of the } \\
\text { retrospective studies. Scores }>8 \text { were } \\
\text { considered high quality and included } \\
\text { in the review. } \\
\text { - The Jadad score was utilized to assess } \\
\text { the methodological quality of the } \\
\text { RCTs. Scores of }>3 \text { were indicative } \\
\text { of a high-quality study and were } \\
\text { included in the review. } \\
\text { PICO and methodological quality of } \\
\text { study were organized in table format } \\
\text { for review. }\end{array}$ \\
\hline Results: & $\begin{array}{l}\text { Were results of review } \\
\text { clearly described in a } \\
\text { critical fashion? In table } \\
\text { and narrative? } \\
\text { Were results similar } \\
\text { across studies? Was a } \\
\text { cross-analysis } \\
\text { performed? } \\
\text { Are the results of all } \\
\text { included studies clearly } \\
\text { displayed? If the study } \\
\text { results were combined, } \\
\text { was it appropriate to do } \\
\text { so? } \\
\text { How precise are the } \\
\text { results? Do the results of } \\
\text { the studies have } \\
\text { significant findings, and } \\
\text { do the researchers } \\
\text { provide evidence of } \\
\text { such? Did the } \\
\text { interpretation of the } \\
\text { review's results } \\
\text { accurately reflect the } \\
\text { actual results? Are } \\
\text { results generalizable? }\end{array}$ &  \\
\hline $\begin{array}{l}\text { Meta- } \\
\text { analysis }\end{array}$ & $\begin{array}{l}\text { Was a meta-analysis } \\
\text { performed? Please } \\
\text { describe. } \\
\text { How are meta-analysis }\end{array}$ & $\begin{array}{l}\text { A Meta-analysis was not conducted } \\
\text { because of lack of uniform definitions } \\
\text { among primary outcomes. }\end{array}$ \\
\hline
\end{tabular}




\begin{tabular}{|c|c|c|}
\hline & $\begin{array}{l}\text { results displayed? } \\
\text { Was a rationale for the } \\
\text { statistics used provided? } \\
\text { Was statistical } \\
\text { significance tested? }\end{array}$ & \\
\hline Discussion & $\begin{array}{l}\text { Was the discussion } \\
\text { section clear and } \\
\text { comprehensive? } \\
\text { What do the main } \\
\text { findings mean } \\
\text { Are the conclusions } \\
\text { justified } \\
\text { How do the findings } \\
\text { compare with what } \\
\text { others have found? } \\
\text { Application of findings } \\
\text { Were limitations } \\
\text { discussed? Implications? }\end{array}$ & $\begin{array}{l}\text { The discussion section was clear and } \\
\text { easy to understand. } \\
\text { Perez-Gonzales et al. (2017) } \\
\text { identified only one of the RCTs } \\
\text { positively tested the hypothesis: PVB } \\
\text { reduced the rate of recurrence after } \\
\text { breast cancer surgery. The study was } \\
\text { inadequately powered and noted } \\
\text { results should be taken with caution. } \\
\text { No association was made between } \\
\text { anesthesia technique and } \\
\text { improvement in survival in } 3 \text { of the } \\
\text { studies. } \\
\text { The review identified significant } \\
\text { limits including: the retrospective } \\
\text { designs, various statistical analysis, } \\
\text { selection bias, heterogeneity in type } \\
\text { of anesthesia technique used, and } \\
\text { lack of detailed information on tumor } \\
\text { description including size, stage, and } \\
\text { adjuvant treatments } \\
\text { (chemo/radiation). } \\
\text { The review concluded a lack of } \\
\text { convincing data to support or contest } \\
\text { regional PVB as a cancer recurrence } \\
\text { reducer or improver in survival rates. } \\
\text { The data supported PVB's effect on } \\
\text { decreasing the inflammatory response } \\
\text { and noted its possible prevention on } \\
\text { immune suppression during surgery. } \\
\text { A cross analysis was not performed } \\
\text { effects of PVB and propofol as a } \\
\text { combination to prevent immune } \\
\text { suppression is recommended. } \\
\text { Propofols anti-inflammatory } \\
\text { study. }\end{array}$ \\
\hline
\end{tabular}


properties will also be explored further.

Note. $\mathrm{PVB}=$ paravertebral regional block; GA= general anesthesia; RCT= randomized control trial; $\mathrm{NK}=$ natural killer; $\mathrm{GF}=$ growth factor. 


\section{Appendix B-1}

Exadaktylos, Buggy, Moriarty, Mascha, and Sessler. (2006). Can anesthetic technique for primary breast cancer surgery affect recurrence or metastasis?

\begin{tabular}{|c|c|c|}
\hline Purpose & Design & Findings \\
\hline $\begin{array}{l}\text { To compare } \\
\text { local cancer } \\
\text { recurrence and } \\
\text { metastases in } \\
\text { patients who } \\
\text { underwent } \\
\text { breast cancer } \\
\text { surgery with } \\
\text { and without } \\
\text { paravertebral } \\
\text { regional } \\
\text { analgesia. }\end{array}$ & Retrospective Study & $\begin{array}{l}\text { - } \text { One hundred and twenty-nine } \\
\text { patients who underwent surgical } \\
\text { mastectomy and axillary clearance } \\
\text { were reviewed. Sixty-five patients } \\
\text { were excluded for not meeting } \\
\text { inclusion criteria. A total of } 50 \\
\text { patients for PVB and } 79 \text { patients for } \\
\text { GA were included. } \\
\text { The median pain score was noted } \\
\text { less in PVB than GA with morphine } \\
\text { analgesia. At } 4 \text { hours PVB vs. GA } \\
\text { 1:3 ( } p=0.02 \text { ), at } 24 \text { hours } 1: 2 \text { ( } p= \\
\text { 0.04). } \\
\text { Incidence of therapies after surgical } \\
\text { treatment did not differ between } \\
\text { groups significantly ( } p>0.05 \text { ) } \\
\text { Recurrence or metastasis } \\
\text { documented in 3:50 PVB patients } \\
\text { (6\%) and 19:79 GA patients (24\%) } \\
\text { Adjusted follow up done with the } \\
\text { Kaplan-Meier analysis; PVB showed } \\
\text { slower times to recurrence ( } p= \\
\text { 0.013). } \\
\text { Multivariable analysis adjusted for } \\
\text { histologic grade and axillary node } \\
\text { involvement ( } p=0.25 \text { and } p=0.01 \text { ), } \\
\text { PVB risk of recurrence was } \\
\text { significantly less HR 0.21, ( } p= \\
\text { E.012) } \\
\text { the PVBaktylos et al. (2006) concluded } \\
\text { patients reduced the risk of } \\
\text { recurrence or metastasis } \\
\text { important role in preserving immune } \\
\text { tunction during surgical intervention. } \\
\text { are known technique is thought to decrease } \\
\text { system, and thus reduce the risk of }\end{array}$ \\
\hline
\end{tabular}




\begin{tabular}{|l|l|l|}
\hline & $\begin{array}{l}\text { tumor metastasis and/or recurrence. } \\
\text { PVB for breast cancer surgery } \\
\text { reduced the risk of } \\
\text { recurrence/metastasis during the } 2 \text { to } \\
\end{array}$ \\
& 4 year follow up. \\
\hline
\end{tabular}




\section{Appendix B-2}

Biki, Mascha., Moriarty., Fitzpatrick, Sessler, and Buggy. (2008). Anesthetic technique for radical prostatectomy surgery affects cancer recurrence: Retrospective analysis

\begin{tabular}{|c|c|c|}
\hline Purpose & Design & Findings \\
\hline $\begin{array}{l}\text { To test the } \\
\text { hypothesis } \\
\text { that recurrence } \\
\text { of prostate } \\
\text { cancer is less } \\
\text { common with } \\
\text { combined } \\
\text { general } \\
\text { anesthesia and } \\
\text { epidural } \\
\text { analgesia than } \\
\text { with general } \\
\text { anesthesia } \\
\text { alone.” }\end{array}$ & Retrospective Study & 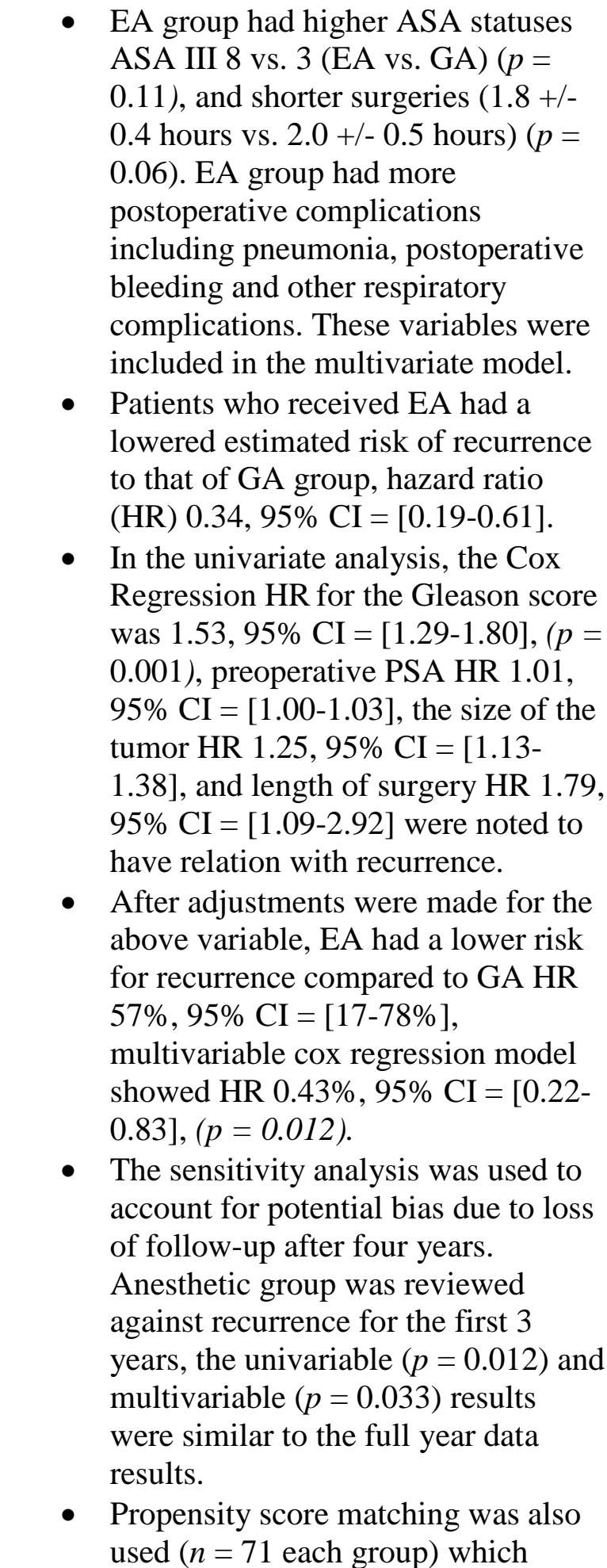 \\
\hline
\end{tabular}









\section{Appendix B-3}

Lin, Liu, Tan, Ouyang, Zhang, and Zeng. (2011). Anesthetic technique may affect prognosis for ovarian serous adenocarcinoma: a retrospective analysis.

\begin{tabular}{|c|c|c|}
\hline Purpose & Design & Findings \\
\hline $\begin{array}{l}\text { To test the } \\
\text { hypothesis that } \\
\text { patients with } \\
\text { ovarian serous } \\
\text { adenocarcinoma } \\
\text { who had } \\
\text { surgery with } \\
\text { epidural } \\
\text { anesthesia and } \\
\text { analgesia would } \\
\text { have better } \\
\text { long-term } \\
\text { outcome than } \\
\text { those who were } \\
\text { given general } \\
\text { anesthesia and } \\
\text { IV opioid } \\
\text { analgesia. }\end{array}$ & Retrospective Study & $\begin{array}{l}\text { - Three- and 5-year overall survival } \\
\text { rates-78\% and 61\% were found in } \\
\text { the EA group, and 58\% and 49\% in } \\
\text { the GA group. Both groups had } \\
\text { attrition with lack of follow-up. } \\
\text { Results suggest patients who } \\
\text { underwent surgical intervention for } \\
\text { ovarian serous adenocarcinoma with } \\
\text { EA had better survival outcomes } \\
\text { than GA patients. } \\
\text { Univariable Cox Regression showed } \\
\text { a higher risk of death for GA } \\
\text { compared to EA with HR of 1.818, } \\
\text { 95\% CI = [1.048-3.153]. The length } \\
\text { of surgery, pre-op status, FIGO stage } \\
\text { and histological grade, residual } \\
\text { tumor, and lymph metastasis } \\
\text { impacted survival rate in univariable } \\
\text { analysis. } \\
\text { The Kaplan-Meier survival rate } \\
\text { estimates and 95\% CIs at follow-up } \\
\text { times showed that EA demonstrated } \\
\text { greater survival rates than GA. The } \\
\text { 1-, 3-, and 5-yr overall survival rates } \\
\text { were as follows: } \\
\text { EA: 96\%, 95\% CI = [92-99\%], 78\% } \\
\text { (95\% CI = [70-86\%], and 61\%, 95\% } \\
\text { CI = [52-71\%]. } \\
\text { GA: 78\%, 95\% CI = [64-91\%], } \\
\text { 58\%, 95\% C =, [42-74\%], and 49\%, } \\
\text { 95\% CI = [32-65\%]. } \\
\text { characteristics: pre-op status, FIGO } \\
\text { stage, histological grade, residual } \\
\text { tumor, and lymph metastasis, the } \\
\text { Multivariable Cox Regression model } \\
\text { was used showing the GA group had } \\
\text { a 21.4\%, 95\% CI = [7.5- 43.1\%] } \\
\text { increased mortality rate compared to } \\
\text { the EA group, with a corresponding } \\
\text { HR of 1.214, 95\% CI = [1.075- }\end{array}$ \\
\hline
\end{tabular}




\begin{tabular}{|c|c|c|}
\hline & 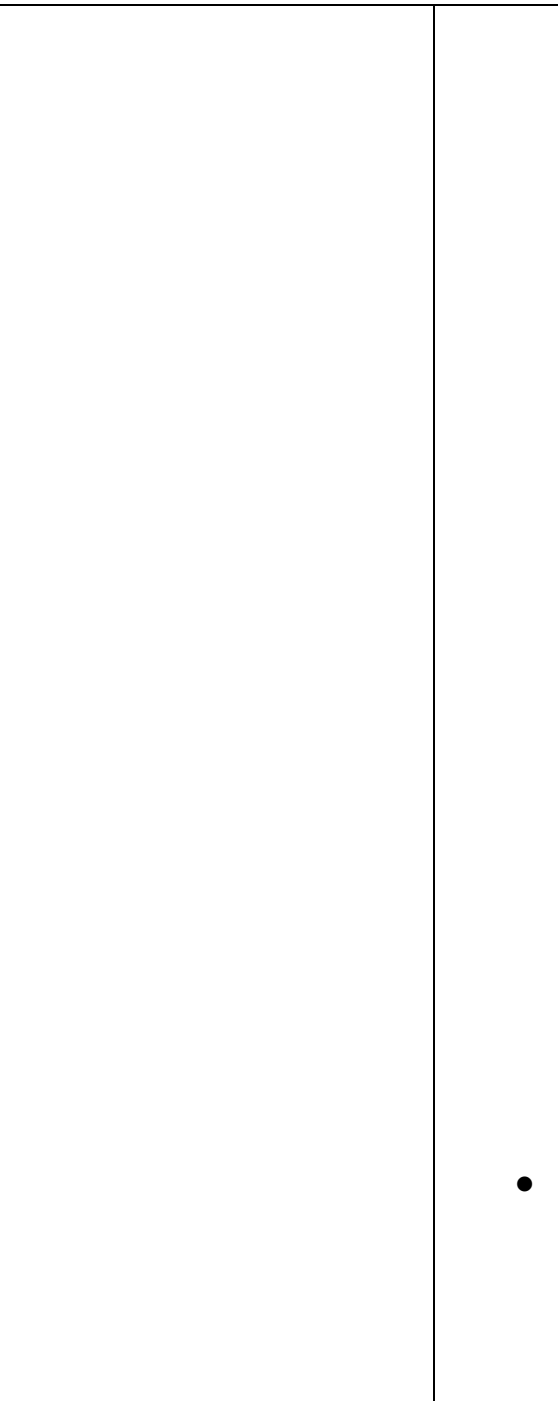 & $\begin{array}{l}\text { 1.431], ( } p=0.043) \text {. } \\
\text {-the association between the } \\
\text { anesthetic group and overall survival } \\
\text { rate were assessed using the first } 5 \\
\text { years of data. The univariable and } \\
\text { multivariable associations were } \\
\text { similar ( } p=0.034 \text { and } 0.045) \text {. } \\
\text { Propensity score matching was used } \\
\text { to assess the association between } \\
\text { anesthesia type/technique and } \\
\text { survival rate. Twenty-nine matched } \\
\text { pairs were obtained ( } n=58 \text { patients). } \\
\text { Anesthesia type and survival rate on } \\
\text { the propensity-matched pairs using } \\
\text { Cox's regression were also } \\
\text { reviewed. GA group: univariable HR } \\
\text { of } 1.322,95 \% \text { CI = [1.083-1.697], } \\
\text { ( } p=0.039) \text { compared with EA } \\
\text { group. A multivariable Cox } \\
\text { regression analysis on the } \\
\text { propensity-matched patients resulted } \\
\text { in an HR of 1.201, 95\% CI = [1.015- } \\
1.502], \\
\text { ( } p=0.042 \text { ). } \\
\text { Analysis suggests that the use of } \\
\text { epidural anesthesia for patients with } \\
\text { ovarian serous adenocarcinoma may } \\
\text { have a reduction in mortality during } \\
\text { initial follow-up years. }\end{array}$ \\
\hline
\end{tabular}




\section{Appendix B-4}

Cummings, Xu, Cummings, and Copper. (2012). A Comparison of Epidural Analgesia and Traditional Pain Management Effects on Survival and Cancer Recurrence after Colectomy A Population-based Study

\begin{tabular}{|c|c|c|}
\hline Purpose & Design & Findings \\
\hline $\begin{array}{l}\text { To compare } \\
\text { cancer } \\
\text { recurrence and } \\
\text { survival rates } \\
\text { of colorectal } \\
\text { surgical } \\
\text { patients who } \\
\text { received } \\
\text { epidurals vs. } \\
\text { those who did } \\
\text { not. }\end{array}$ & Population-based study &  \\
\hline
\end{tabular}




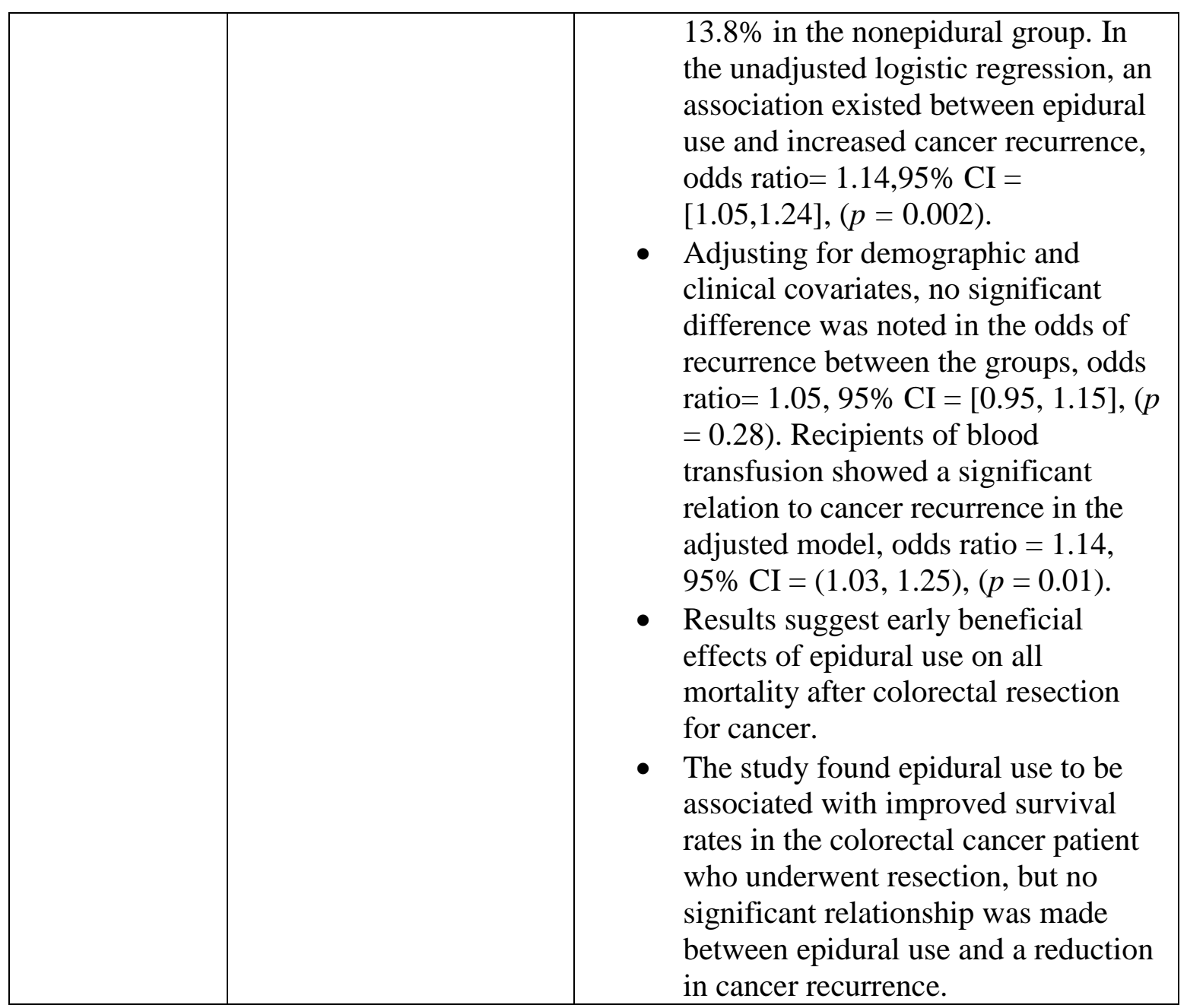




\section{Appendix B-5}

Chen, and Miao. (2013). The effect of anesthetic technique on survival in human cancers: A Meta-analysis of Retrospective and Prospective Studies

\begin{tabular}{|c|c|c|}
\hline Purpose & Design & Findings \\
\hline $\begin{array}{l}\text { To test a given } \\
\text { hypothesis that } \\
\text { patients with } \\
\text { cancer who } \\
\text { underwent } \\
\text { surgical } \\
\text { intervention } \\
\text { under epidural } \\
\text { anesthesia vs. } \\
\text { those who } \\
\text { underwent } \\
\text { general } \\
\text { anesthesia } \\
\text { would have } \\
\text { better } \\
\text { outcomes; } \\
\text { reduced cancer } \\
\text { recurrence and } \\
\text { improved } \\
\text { overall } \\
\text { survival rates. }\end{array}$ & Meta-analysis & 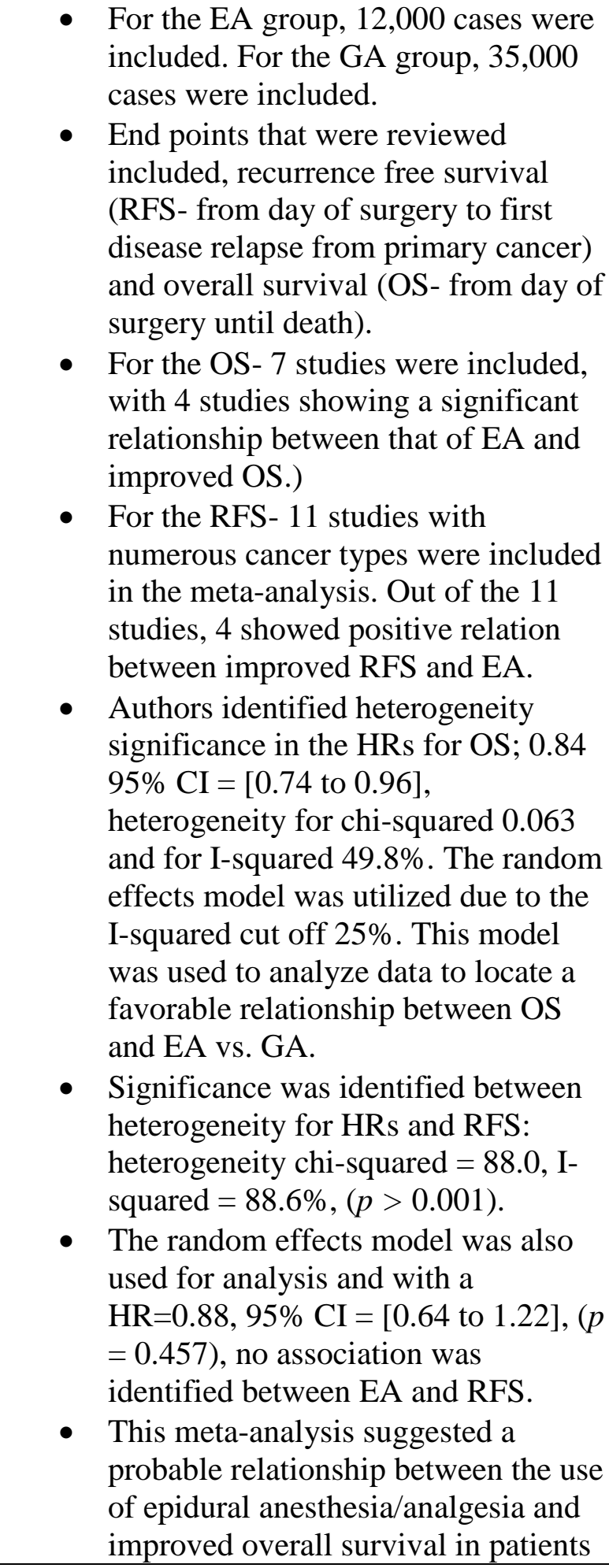 \\
\hline
\end{tabular}




\begin{tabular}{|c|c|c|}
\hline & & $\begin{array}{l}\text { undergoing colorectal cancer surgery. } \\
\text { Chen and Miao (2013) note this } \\
\text { analysis does not support a } \\
\text { relationship between epidural } \\
\text { anesthesia and cancer control. The } \\
\text { need for prospective studies was } \\
\text { recommended to determine a } \\
\text { causative association between } \\
\text { survival and epidural use }\end{array}$ \\
\hline
\end{tabular}




\section{Appendix B-6}

Jang, Lim, Shin, Kwon Ko, Park, Hyun Song, and June Kim, B. (2016). A comparison of regional and general anesthesia effects on 5 years survival and cancer recurrence after transurethral resection of the bladder tumor: a retrospective analysis

\begin{tabular}{|c|c|c|}
\hline Purpose & Design & Findings \\
\hline $\begin{array}{l}\text { To determine } \\
\text { if mortality } \\
\text { from bladder } \\
\text { cancer is } \\
\text { different } \\
\text { between } \\
\text { patients who } \\
\text { underwent } \\
\text { surgical } \\
\text { intervention } \\
\text { with general } \\
\text { anesthesia vs. } \\
\text { regional } \\
\text { anesthesia. }\end{array}$ & Retrospective Study & 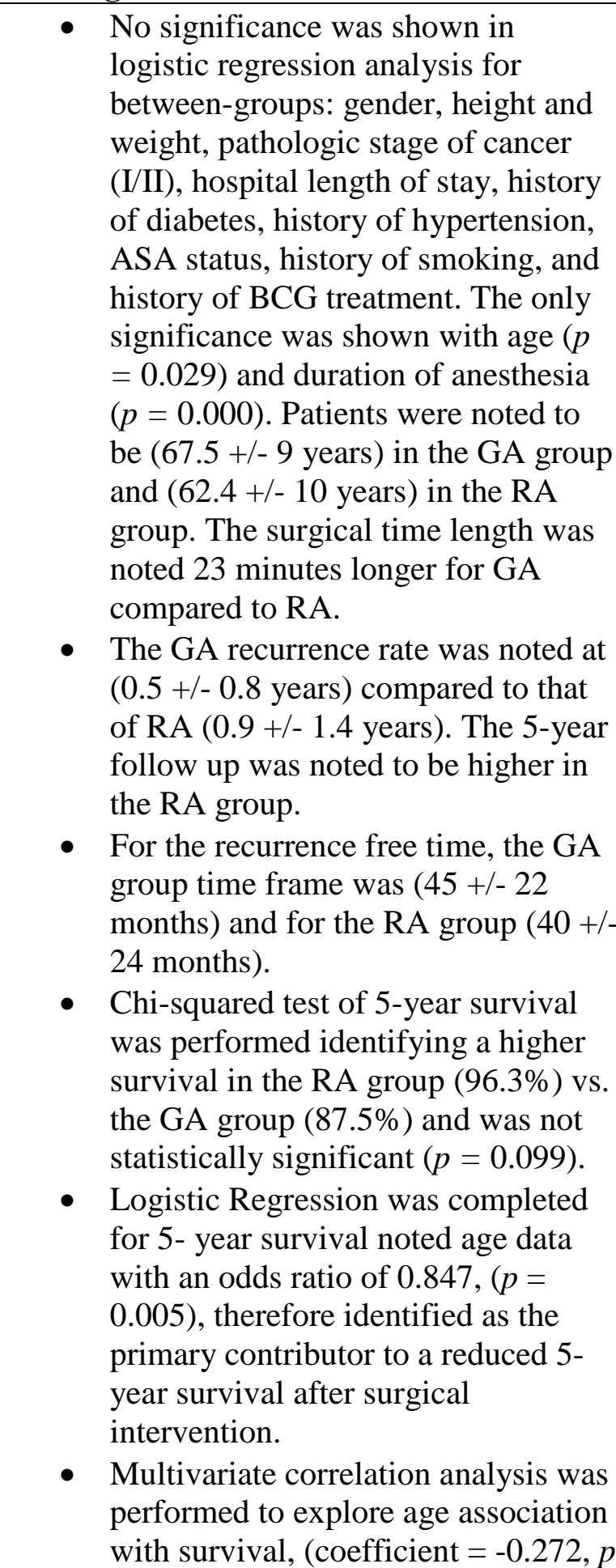 \\
\hline
\end{tabular}




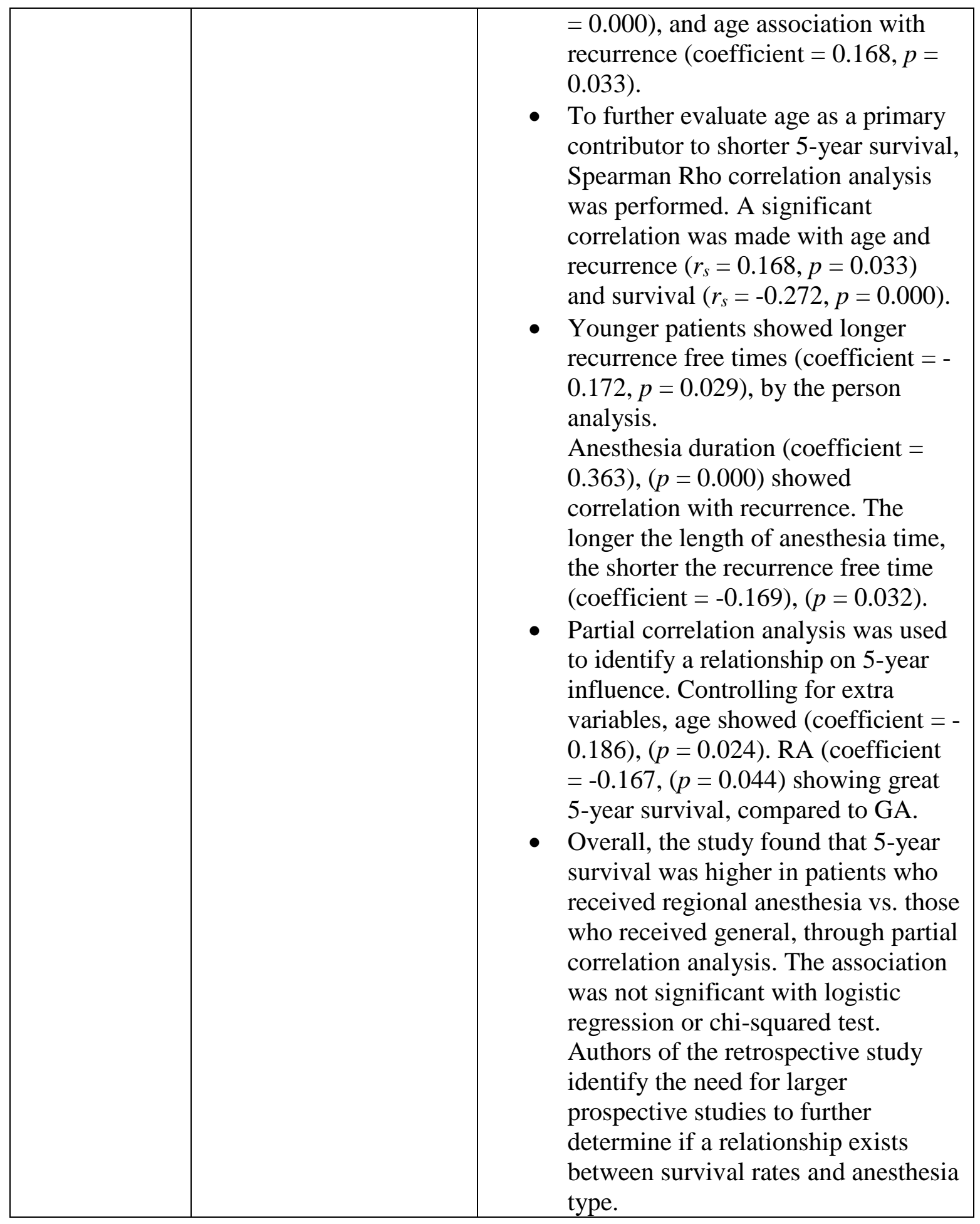




\section{Appendix B-7}

Cho, Lee, Kim, Park, Park, Oh, Ho Lee, and Koo. (2017). The effects of perioperative anesthesia and analgesia on immune function in patients undergoing breast cancer resection: a prospective randomized study

\begin{tabular}{|c|c|c|}
\hline Purpose & Design & Findings \\
\hline $\begin{array}{l}\text { To compare } \\
\text { the effects of } \\
\text { two different } \\
\text { types of } \\
\text { anesthetic/ } \\
\text { analgesic } \\
\text { methods on } \\
\text { the natural } \\
\text { killer cell } \\
\text { cytotoxicity of } \\
\text { patients } \\
\text { undergoing } \\
\text { elective } \\
\text { surgery for } \\
\text { breast cancer. }\end{array}$ & $\begin{array}{l}\text { A Prospective } \\
\text { Randomized Study }\end{array}$ & $\begin{array}{l}\text { Baseline NKCC (\%) between the two } \\
\text { groups ( } p=0.082) \text {. Compared with } \\
\text { the baseline value, NKCC (\%) } \\
\text { increased in the Propofol-Ketorolac } \\
\text { group [15.2 (3.2) to } 20.1 \text { (3.5)], ( } p= \\
\text { 0.048), whereas it decreased in the } \\
\text { Sevoflurane-Fentanyl group [19.5 } \\
\text { (2.8) to } 16.4(1.9) \text { ], ( } p=0.032) \text {. The } \\
\text { change of NKCC over time was } \\
\text { significantly different between the } \\
\text { groups ( } p=0.048) \text {. } \\
\text { Pain scores during } 48 \text { hours after } \\
\text { surgery and post-surgical } \\
\text { inflammatory responses were } \\
\text { comparable between the groups. } \\
\text { IL-2 concentration showed no } \\
\text { significant postoperative changes in } \\
\text { either group preoperative to } \\
\text { postoperative; } 2.75 \text { (1.61, } 4.97) \text { to } \\
\text { 3.16 (1.97, 5.52), ( } p=0.721) \text { in the } \\
\text { P-R-K group, and 2.65 (2.15, 3.96) to } \\
\text { 2.81 (2.00, 4.62), ( } p=0.523 \text { ) in the } \\
\text { S-R-F group. The change of IL-2 } \\
\text { levels over time was not significant } \\
\text { between the groups ( } p=0.620) \text {. } \\
\text { Inflammatory response: Changes of } \\
\text { total leukocyte, neutrophil, and } \\
\text { lymphocyte counts and NLR over } \\
\text { time were not significant between the } \\
\text { groups. Lymphocyte counts after } \\
\text { surgery decreased in both groups } \\
\text { compared to the baseline, but the } \\
\text { difference was significant only in the } \\
\text { the } \text {-R-F group ( } p=0.037) \text { group had recurrence in } \\
\text { after surgery and underwent a partial } \\
\text { mastectomy. No patient had } \\
\text { metastasis in either group within two }\end{array}$ \\
\hline
\end{tabular}




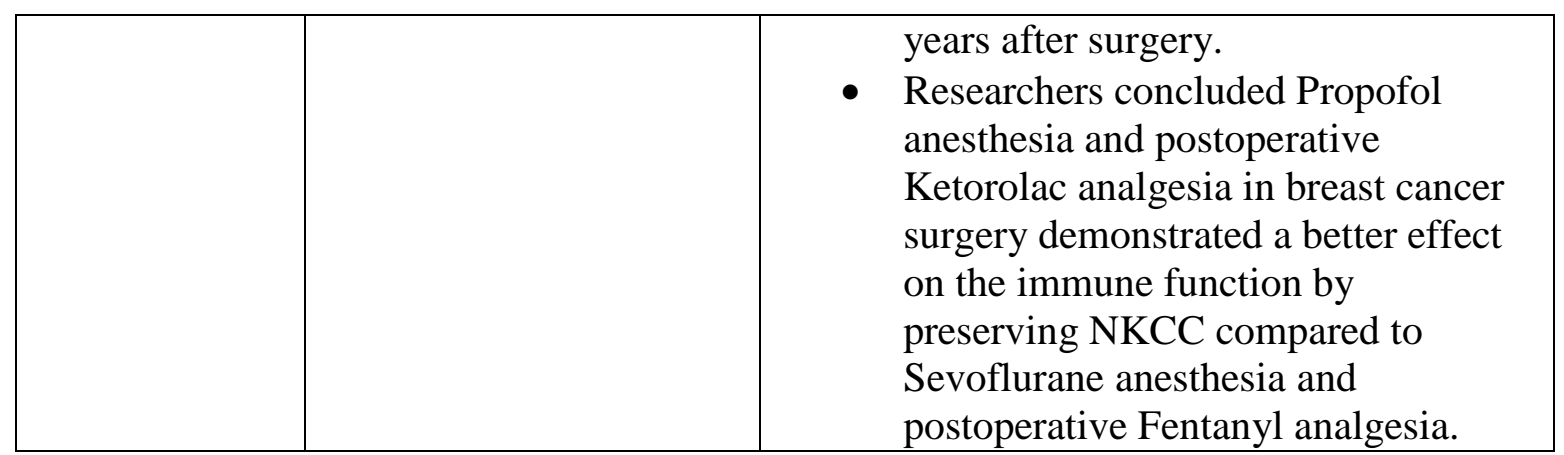




\section{Appendix B-8}

Peres-Gonzales, Cuellar-Guzman, Soliz, and Cata. (2017). Impact of reginal anesthesia on recurrence, metastasis, and immune response in breast cancer surgery: a systematic review of the literature.

\begin{tabular}{|c|c|c|}
\hline Purpose & Design & Findings \\
\hline $\begin{array}{l}\text { To assess the } \\
\text { impact of } \\
\text { regional } \\
\text { anesthesia on } \\
\text { metastasis, } \\
\text { inflammation, } \\
\text { and } \\
\text { immunosuppre- } \\
\text { ssion during } \\
\text { breast cancer } \\
\text { surgery, and } \\
\text { recurrence of } \\
\text { cancer after } \\
\text { surgical } \\
\text { intervention. }\end{array}$ & $\begin{array}{l}\text { Systematic Review of the } \\
\text { Literature }\end{array}$ & $\begin{array}{l}\text { - Six studies investigated the } \\
\text { association between PVB/ propofol } \\
\text { and volatile GA/opioid-based } \\
\text { anesthesia on cancer recurrence } \\
\text { rates, overall survival, recurrence } \\
\text { free survival, and cancer-specific } \\
\text { survival. } \\
\text { All studies, except one, were } \\
\text { retrospective and included sample } \\
\text { sizes ranging from } 60 \text { to } 1107 \\
\text { patients. The only RCT showed no } \\
\text { difference in rate of recurrence } \\
\text { between PVB vs. GA (Finn et } \\
\text { al.,2017). } \\
\text { For the retrospective studies, only } 1 \\
\text { study showed any association of } \\
\text { PVB and the reduction of cancer } \\
\text { recurrence. Exadaktylos et al. } \\
\text { (2006) showed the patients who } \\
\text { received regional anesthesia with } \\
\text { PVB/propofol, had a slower time to } \\
\text { the rate of cancer recurrence vs. the } \\
\text { GA group. Recurrence time was } \\
\text { 24\% for the GA group vs. 6\% for } \\
\text { the PVB/propofol group HR 0.21, } \\
\text { (p = 0.012) } \\
\text { Four RCTs studied the impact of } \\
\text { PVB on Biomarkers. Studies } \\
\text { showed minimal to no difference in } \\
\text { inflammatory biomarkers and } \\
\text { markers of stress response between } \\
\text { regional and general anesthesia } \\
\text { (Deegan et al., 2010; Looney et al., } \\
\text { angiogenesis/proliferation in the } \\
\text { PVB/propofol group and the GA } \\
\text { group. The concentrations of GF in }\end{array}$ \\
\hline
\end{tabular}




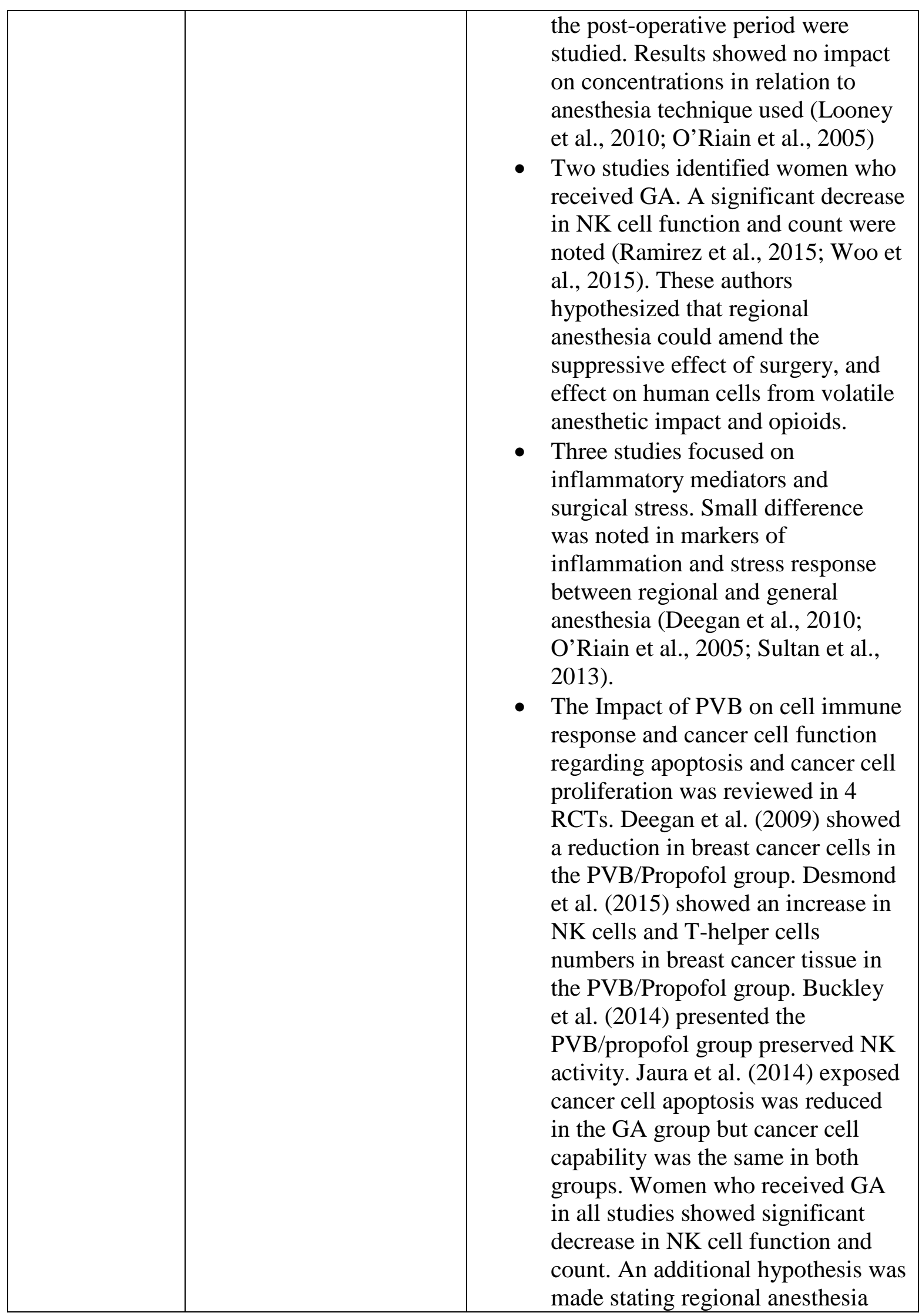




\begin{tabular}{|l|l|}
\hline & $\begin{array}{l}\text { could ameliorate the suppressive } \\
\text { effects from surgery, volatile } \\
\text { anesthetics and opioid on the cells. } \\
\text { - } \\
\text { Two studies involving anesthetic } \\
\text { effect during breast cancer surgery } \\
\text { on proliferation and apoptosis of } \\
\text { cells showed antiapoptopic effects } \\
\text { in women who received a GA and } \\
\text { inhibition of cell proliferation after } \\
\text { exposure to PVB (Deegan et al., } \\
\text { 2010; Jaura et al., 2014). } \\
\text { Two RCTs presented data that after } \\
\text { mastectomy surgery, women who } \\
\text { received PVB anesthesia showed } \\
\text { NK cell preservation vs. the women } \\
\text { who received GA (Buckley et al., } \\
\text { 2014; Desmond et al., 2015). } \\
\text { The review found a low level of } \\
\text { supportive evidence of the impact } \\
\text { of regional anesthesia on survival } \\
\text { outcomes after surgical intervention } \\
\text { for breast cancer. }\end{array}$ \\
\\
\end{tabular}




\section{Appendix C}

Cross Table Analysis

\begin{tabular}{|c|c|}
\hline Author & Exadaktylos et al. (2006). \\
\hline Key Findings & $\begin{array}{l}\text {-Paravertebral anesthesia and analgesia } \\
\text { reduce the chance of recurrence/metastasis } \\
\text { after breast cancer surgery compared to } \\
\text { general anesthesia. } \\
\text {-Recurrence/metastasis was documented in } \\
6 \% \text { of patients in the paravertebral group } \\
\text { and } 24 \% \text { in the general anesthesia group. }\end{array}$ \\
\hline Recommendations & $\begin{array}{l}\text {-Limited by the retrospective design and } \\
\text { small sample size. } \\
\text {-Authors suggests the need for prospective } \\
\text { trials to further evaluate the impact of } \\
\text { regional anesthesia with analgesia on } \\
\text { cancer recurrence. }\end{array}$ \\
\hline Author & Biki et al. (2008). \\
\hline Key Findings & $\begin{array}{l}\text {-Patients who received general anesthesia } \\
\text { with epidural analgesia had a } 57 \% \text { reduced } \\
\text { risk of cancer recurrence compared to } \\
\text { patients who received general anesthesia } \\
\text { with postoperative opioids. } \\
\text {-Propensity score matching was used to } \\
\text { even the epidural analgesia group and the } \\
\text { general with opioid analgesia group to } \\
\text { improve the balance and reliability of the } \\
\text { study. After matching, a } 52 \% \text { risk reduction } \\
\text { was noted. This showed similar results to } \\
\text { the } 57 \% \text { risk reduction with general } \\
\text { anesthesia with epidural analgesia } \\
\text { compared to the general anesthesia with } \\
\text { opioid analgesia. }\end{array}$ \\
\hline Recommendations & $\begin{array}{l}\text {-Limited by uneven group sizes, unequal } \\
\text { ASA scores different complications and } \\
\text { different surgery lengths. } \\
\text {-Other limitations include non- } \\
\text { randomization, non-standardized clinical } \\
\text { care, }\end{array}$ \\
\hline
\end{tabular}




\begin{tabular}{|c|c|}
\hline & $\begin{array}{l}\text {-Authors suggests the need for larger } \\
\text { randomized controlled trials. }\end{array}$ \\
\hline Author & Lin et al. (2011). \\
\hline Key Findings & $\begin{array}{l}\text {-Survival rates for three years following } \\
\text { surgical intervention showed survival rates } \\
\text { of } 78 \% \text { for the epidural anesthesia group, } \\
\text { compared to } 58 \% \text { in the general anesthesia } \\
\text { group. } \\
\text { Five year follow up showed survival rates } \\
\text { of } 61 \% \text { in the epidural anesthesia group vs. } \\
49 \% \text { in the general anesthesia group. } \\
\text { The study suggests the use of epidural } \\
\text { anesthesia during the surgical intervention } \\
\text { of ovarian serous adenocarcinoma may } \\
\text { reduce mortality during early years } \\
\text { following surgery. }\end{array}$ \\
\hline Recommendations & $\begin{array}{l}\text {-The authors identify testable possibilities. } \\
\text {-Important limitations to the study include; } \\
\text { non-randomization, uneven sample sizes } \\
\text { and confounding variable impact that } \\
\text { cannot be excluded. } \\
\text {-Authors identify the need for randomized } \\
\text { controlled trials to compare epidural } \\
\text { anesthesia and general anesthesia and the } \\
\text { impact on ovarian cancer outcomes. }\end{array}$ \\
\hline Author & Cummings et al. (2012). \\
\hline Key Findings & $\begin{array}{l}\text {-This cohort study identified five-year } \\
\text { survival was greater in colon cancer } \\
\text { patients who underwent colon resections } \\
\text { with epidural anesthesia compared to } \\
\text { general anesthesia ( } 61 \% \text { vs. } 55 \%) \text {. } \\
\text {-Cancer recurrence- measured using } \\
\text { chemotherapy or radiation, however, did } \\
\text { not significantly differ between the two } \\
\text { groups ( } 14.3 \% \text { epidural vs. } 13.8 \% \text { general). }\end{array}$ \\
\hline Recommendations & $\begin{array}{l}\text {-Authors identify that compared to earlier } \\
\text { studies, the results of this study are minor at } \\
\text { best. } \\
\text {-Authors identify the need for clinical trials }\end{array}$ \\
\hline
\end{tabular}




\begin{tabular}{|c|c|}
\hline & $\begin{array}{l}\text { to evaluate the differences in tumor } \\
\text { biology, different patient populations and } \\
\text { long term follow up obstacles. } \\
\text {-Authors acknowledge significant } \\
\text { association between intraoperative blood } \\
\text { transfusions and increased cancer } \\
\text { recurrence and mortality and identify the } \\
\text { need for further investigation into blood } \\
\text { transfusions and anesthesia impacts on } \\
\text { colon cancer patients for cancer recurrence. } \\
\text {-Limitations to the study include; weakness } \\
\text { of an observational study, selection bias, } \\
\text { unmeasured confounding variables, limited } \\
\text { clinical data (types of drugs administered), } \\
\text { and timing of epidural placement. }\end{array}$ \\
\hline Author & Chen and Miao. (2013). \\
\hline Key Findings & $\begin{array}{l}\text {-SEER based study showed significant } \\
\text { positive outcomes on all-cause mortality of } \\
\text { patients with colorectal cancer after } \\
\text { epidural use. } \\
\text {-The Prospective Master trial did not } \\
\text { identify any difference in overall survival } \\
\text { for patients with abdominal cancers } \\
\text { undergoing surgical intervention with } \\
\text { epidural anesthesia. } \\
\text {-Results suggest that the use of epidural } \\
\text { anesthesia may be associated with } \\
\text { improved overall survival in the surgical } \\
\text { cancer patient. }\end{array}$ \\
\hline Recommendations & $\begin{array}{l}\text {-Authors identify the need for prospective } \\
\text { studies to validate a causative association } \\
\text { between survival and epidural use }\end{array}$ \\
\hline Author & Jang et al. (2016). \\
\hline Key Findings & $\begin{array}{l}\text {-Five-year survival for regional anesthesia } \\
\text { (spinal or epidural) was } 96 \% \text { vs. } 87.5 \% \text { for } \\
\text { general anesthesia for patients undergoing } \\
\text { bladder cancer surgical intervention- found } \\
\text { by partial correlation analysis. } \\
\text {-Older age was a significant factor that } \\
\text { reduced survival in both groups ( } p=0.001 \text { ) }\end{array}$ \\
\hline
\end{tabular}




\begin{tabular}{|c|c|}
\hline & $\begin{array}{l}\text {-Chi-square and logistic regression did not } \\
\text { find significant association between the } \\
\text { two. } \\
\text {-Therefore, the effects of general vs. } \\
\text { regional anesthesia on cancer recurrence } \\
\text { and 5-year survival after bladder resection } \\
\text { cannot be certain. }\end{array}$ \\
\hline Recommendations & $\begin{array}{l}\text {-Authors acknowledge the need for larger } \\
\text { prospective studies to determine a causative } \\
\text { association between regional anesthesia and } \\
\text { survival. }\end{array}$ \\
\hline Author & Cho et al. (2017). \\
\hline Key Findings & $\begin{array}{l}\text {-Natural killer cells increased with the use } \\
\text { of propofol and ketorolac group (15.2 to } \\
20.1, p=0.048 \text { ) and decreased in the } \\
\text { sevoflurane and fentanyl group (19.5 to } \\
16.4, p=0.032 \text { ). } \\
\text {-No metastasis found in either group. } \\
\text {-Recurrence found in contralateral breasts } \\
\text { of sevoflurane/fentanyl group patient. } \\
\text {-Incidence between the two groups for } \\
\text { short-term recurrence was not significant } \\
\text { between groups. } \\
\text {-Findings in this study are consistent with } \\
\text { the hypothesis of avoiding volatile } \\
\text { anesthetics (general anesthesia) and opioids } \\
\text { to potentially decrease immunosuppression } \\
\text { during surgery and decrease the risk of } \\
\text { cancer spread. }\end{array}$ \\
\hline Recommendations & $\begin{array}{l}\text {-Authors recommend further investigation } \\
\text { and studies to identify anesthetic methods } \\
\text { to avoid immunosuppression in cancer } \\
\text { surgery. }\end{array}$ \\
\hline Author & Pere-Gonzales et al. (2017). \\
\hline Key Findings & $\begin{array}{l}\text {-This systematic review indicated that there } \\
\text { was no data to disprove or support the use } \\
\text { of paravertebral blocks for cancer }\end{array}$ \\
\hline
\end{tabular}




\begin{tabular}{|l|l|}
\hline & $\begin{array}{l}\text { recurrence reduction or cancer survival } \\
\text { improvement. }\end{array}$ \\
Recommendations & $\begin{array}{l}\text {-Authors do identify an association between } \\
\text { paravertebral block and a decrease in } \\
\text { inflammation and thus better overall } \\
\text { immune system response compared to that } \\
\text { of general anesthesia. }\end{array}$ \\
\hline $\begin{array}{l}\text {-Authors identify a current randomized } \\
\text { control trial currently enrolling cancer } \\
\text { patients with random assignment to } \\
\text { epidural anesthesia/analgesia and general } \\
\text { anesthesia with opioid analgesia to identify } \\
\text { the better anesthetic choice for cancer } \\
\text { patients. This study is said to finish } \\
\text { recruitment in 2019. }\end{array}$ \\
\hline
\end{tabular}

